\title{
CELULAR: Representações das desigualdades na mobilidade
}

Dissertação apresentada ao Programa de PósGraduação em Ciências da Comunicação, Área de Concentração Estudos dos Meios e da Produção Mediática. Linha de Pesquisa, Comunicação Impressa e Audiovisual da Escola de Comunicações e Artes da Universidade de São Paulo, como exigência parcial para obtenção do Título de Mestre, sob a orientação do Prof. Dr. Mauro Wilton de Sousa. 
CHRISTIAN JUSTINO DE GODOI

\section{CELULAR: Representações das desigualdades na mobilidade}

Dissertação apresentada ao Programa de PósGraduação em Ciências da Comunicação, Área de Concentração Estudos dos Meios e da Produção Mediática. Linha de Pesquisa, Comunicação Impressa e Audiovisual da Escola de Comunicações e Artes da Universidade de São Paulo, como exigência parcial para obtenção do Título de Mestre, sob a orientação do Prof. Dr. Mauro Wilton de Sousa. 
La pauvreté volontaire, c'est le choix libre et éclairé d'um être humain que as quête de bien-etre conduit à vivre dans la plus grande simplicité, quel que soit le contexte extérieur.

Rahnemah (2003, p. 145) 
Aos meus pais, Lúcia e Euclides. 


\section{AGRADECIMENTOS}

Primeiramente ao amigo e prof. Dr. Mauro Wilton de Sousa, pela confiança e dedicação.

Ao prof. Dr. Eugênio Trivinho pelos ensinamentos durante o percurso.

Aos professores das disciplinas cursadas durante o período em que estive na USP: prof. Dra. Cristina Costa, prof. Dr. Wladimir Safatle, prof. Dra. Jeanne Marie de Freitas, prof. Dra. Maria Immacullata V. de Lopez, prof. Dr. Gilson Schwarttz, prof. Dra. Esther Hamburger, prof. Dr. Brasílio Sallum, prof. Dra. Cremilda Medina.

À prof. Dra. Elisabeth Saad, que com seus apontamentos contribuiu para a evolução do trabalho.

Aos pesquisadores de campo que tornaram esta pesquisa uma realidade: Susan Ribeiro Hortas, Noelle Frate Falchi, Bárbara Baeta Ribas, Carmen Prado, Camila Mariano, Alex Fernandes da Silva, Cássia Souza Luz, Evaldo Júnior Bento.

A minha mulher Ana Lúcia Rente Correia e Godoi, e ao amigo Adalberto Pinheiro Lima. 


\section{Resumo:}

Com a participação do telefone celular no cotidiano de boa parte da população mundial têm-se uma prótese que amplia espaços, tempos, e formas diferenciadas de significação, a partir de um mecanismo que possibilita a produção de significados nos diversos apetrechos nele hibridados. Surgem então espaços comunicacionais nos quais diversas relações se efetivam. Os sentidos produzidos a partir do aparelho, então, passam a reproduzir o mundo de seus usuários. Nesses espaços celulares é possível assemelhar-se, graças à democratização das tecnologias disponibilizadas para todos, ou diferenciarse e, conseqüentemente, simbolizar a desigualdade. Têm-se, com isso, o instrumento celular como reprodutor de desigualdade.

Palavras-chave: celular, desigualdade, práticas culturais, simbólico. 


\begin{abstract}
:
With mobile participation daily next to part of world population, we have a protease that augmenters spaces, times, and different structures of significance, also for numerous hybrids device him. Arise communications spaces where several possibilities of relationships. The signification produces whit that device reproduces the world of the people. In this cell phone spaces is possible resemble or disagree, and with this, to represent the inequality. We have therefore the cell phone reprinting this inequality.
\end{abstract}

Key-words: cellular, inequality, cultural practices, symbolic. 


\section{Lista de tabelas e gráficos}

Tabela 1. Número de celulares no mundo a partir de 2004, p. 14

Gráfico 1. Evolução de celulares no mundo, p. 15

Tabela 2. Número de celulares no mundo, p. 15

Tabela 3. Número de celulares na América Latina, p. 16

Tabela 4. Percentual de domicílios com aparelhos comunicacionais, p. 17

Tabela 5. Celulares no Brasil em Ago/08, p. 17

Tabela 6. Sistemas de transmissão de dados por celular, p. 18

Tabela 7. Tecnologias no Brasil, p. 19

Tabela 8. Locais, renda, profissão, p. 82

Tabela 9. Locais, renda, veículos, p. 83

Tabela 10. Locais, renda, celular pré-pago e pós-pago, p. 84

Tabela 11. Locais, renda, operadoras selecionadas, p. 85

Tabela 12. Locais, renda, situação de usos, p. 87

Tabela 13. Locais, renda, tecnologias híbridas ao celular, p. 92

Tabela 14. Locais, renda, locais de uso, p. 96 


\section{Sumário}

\section{Dedicatória, i}

Agradecimentos, ii

Resumo, ifi

Abstract, iv

\section{Lista de Tabelas e Gráficos, v}

\section{INTRODUÇÃO}

1.1 O celular no tempo e no espaço como dispositivo simbólico, p. 13

Telefone celular no Brasil: uma prática emergente, p. 16

Tecnologias de transmissão em constante atualização, p. 17

Os instrumentos celulares e razões de usos, p. 20

Espaços híbridos e territórios informacionais: objeto de estudo, p. 21

1.2 Simbolismo celular: a pertinência cultural do seu uso, p. 23

O celular e as expressões da desigualdade no seu uso, p. 26

Indicadores em construção, p. 27

Metodologia, p. 30

\section{O TELEFONE CELULAR NA DESIGUALDADE}

2.1 Desigualdade: uma questão de classe? p. 34

2.2 Desigualdade nas manifestações contemporâneas, p. 38

2.3 Desigualdade comunicacional, p. 42

\section{O SIMBÓLICO, AS PRÁtICAS E A DEMOCRACIA NO CELULAR}


3.1 O usuário e os sentidos nos usos do celular, p. 51

Igualdade celular, p. 53

Desigualdade celular, p. 55

3.2 Celular e pós-modernidade, p. 57

Práticas culturais e democracia, p. 60

Comunicação e efetivação da democracia, p. 63

A comunicação em transição, p. 64

\section{O CELULAR E SUA EXPRESSÃo SimbóliCA: TECNOLOGIAS SEMELHANTES EM USOS DESIGUAIS EM PRÁTICAS EMPÍRICAS}

4.1 Celular: necessidades e desigualdades aparentes, p. 70

Espaços empíricos de representações culturais, p. 73

Celular: tecnologias semelhantes, usos desiguais, p. 76

Celular como espaço paradoxal em lugares antagônicos, p. 79

4.2 Ação com celular, p. 83

O que se faz no celular, p. 87

Os usos em respostas espontâneas, p. 91

V. CONSIDERAÇÕES FINAIS, P. 97

VI. REFERÊNCIAS BIBLIOGRÁFICAS, P. 105

ANEXOS, P. 101 


\section{INTRODUÇÃO}

“Celular não é para falar, é para se achar. É pra usar na hora, é instantâneo ${ }^{1}$." A afirmação aponta para uma função visceral do telefone celular, talvez a primeira. Falar em movimento - sempre para se achar --, contudo, nem sempre é confortável ou permitido, daí uma das perguntas mais comuns quando se atende a uma ligação no celular seja "onde você está?" Isso demonstra a preocupação do outro com a sua disponibilidade para ouvi-lo, mas reflete também uma curiosidade real de saber onde você se encontra. Falar, encontrar e ser encontrado: primeiro ato.

O telefone celular, contudo, evoluiu e agregou inúmeros outros mecanismos e funções que se mostram úteis, necessários, agradáveis, ou supérfluos. Essa evolução do aparelho celular acompanhou uma revolução nos modos de socializar, de comungar de um mesmo espaço, de retratar os cotidianos, de incluir, de aquisição de prestígio. Textos, músicas, luz, câmera, ação, o celular passa a protagonizar: segundo ato.

O aparelho móvel retrata desejos dos indivíduos, das massas, dos consumidores, dos artistas, enfim daquele que quer existir no espaço comum; traduz suas necessidades, escancara suas possibilidades, apresenta suas visões de mundo (através daquilo que nele é armazenado) e de suas objetivações (ou o que seria se pudesse). Enfim, o celular traduz um pouco daquele que o possui em sua personalização: qual a cor escolhida, a ilustração na tela, o toque, os outros aparelhos nele hibridados e o que retratam, onde se reproduzem e o que reproduzem. O celular simboliza: terceiro ato.

O celular, portanto, deixou de ser somente para "se achar", encontrar quem se procura. É mais: é hoje uma tecnologia extremamente carregada de significação pela facilidade de possuí-lo, pelos instrumentos que agrega, pelo que representa para seu proprietário. Ele compõe o e intervém no universo social, como nunca, diferentemente do seu início. Pode-se dizer que o atual

\footnotetext{
${ }^{1}$ ALMEIDA, Maria Isabel M. de, TRACY, Kátia Maria de A. Noites nômades: espaço e subjetividade nas culturas jovens contemporâneas. Rio de Janeiro: Rocco, 2003, p. 35.
} 
momento, com a inserção do telefone celular, representa um clímax em que relações inigualáveis apontam para uma revolução comunicacional.

\subsection{0 celular no tempo e no espaço como dispositivo simbólico}

O aparelho de comunicação móvel apareceu de modo embrionário nos radiotransmissores das forças armadas norte-americanas ${ }^{2}$, como instrumento de vigilância. No final da década de 40 a possibilidade de deslocamento entre células $^{3}$ renovou o conceito de telefonia móvel, mas somente nos anos 70 o celular começou a ser disponibilizado para um público seleto e abastado ${ }^{4} \mathrm{em}$ Nova lorque.

Com a redução do tamanho dos aparelhos e um custo mais acessível o telefone celular popularizou-se ao longo da década de 1990, não somente pelo serviço de voz (ligações) como também por uma segunda função ${ }^{5}$ o SMS (Short Message Service) ou torpedo: a possibilidade de envio e recebimento de mensagens de texto. Posteriormente os jogos, as telas coloridas e os ringtones $^{6}$ passaram a fazer parte da rotina dos usuários. Mas é com as câmeras fotográficas, filmadoras, rádio FM e podcasts digitais, e com o poder

2 A mobilidade comunicacional por ondas de rádio começou a ser desenvolvida para sistemas de segurança e de emergência nos Estados Unidos desde 1921, mas somente após a segunda Guerra Mundial a Comissão Federal de Comunicações norte-americana (FCC - Federal Communications Commission), que controla transmissões por espectro de rádio, passou a criar e comercializar canais móveis de comunicação.

Com a implantação do DPLMRS (Domestic Public Land Mobile Radio Service), em 1946, surgiu o primeiro "sitema de correspondência público" de comunicação móvel sem fio e por ondas de rádio, baseado no sistema push to talk (PTT), este modelo, no entanto, "não permitia que a linha estivesse disponível para a fala de duas pessoas ao mesmo tempo", com isso era necessário que "um dos interlocutores liberasse a linha para que o outro pudesse falar. (MANTOVANI, Camila Maciel C. A. Infoentretenimento na telefonia celular: informação, mobilidade interação social e um novo espaço de fluxos. Belo Horizonte: Escola de Ciência da Informação, UFMG, 2006)

${ }^{3}$ O modelo de célula que caracteriza a transmissão e a mobilidade do aparelho foi criado pelos Laboratórios Bell, em 1947, denominado Improved Mobile Telephone Service (IMTS) deu origem ao primeiro sistema de telefonia móvel e eliminou o PTT. Telefone celular é, portanto, um aparelho telefônico portátil e móvel que possibilita o deslocamento do usuário entre células constituídas a partir de antenas espalhadas pela cidade. (SOUZA E SILVA, Adriana. Do ciber ao híbrido: tecnologias móveis como interfaces de espaços híbridos. In: ARAÚJO, Denise Correa. Imagem (ir)realidade: comunicação e cibermídia. Porto Alegre: Sulina, 2006, p. 36)

${ }^{4}$ Desde o princípio o aparelho despertou o interesse dos indivíduos (mas até 1976 apenas 545 clientes em Nova Iorque possuíam telefone móvel, entre uma lista de espera de mais de três mil pessoas), no entanto até o início dos anos 80 a FCC disponibilizou poucos canais para uso em telefonia móvel. Somente em 1984 passa a ser comercializado o DynaTAC 8000, primeiro aparelho comercial (com cerca de um quilo e $25 \mathrm{~cm}$ de comprimento, $7 \mathrm{~cm}$ de largura e três de espessura, caro e com preços de ligação proibitivos). (MANTOVANI, C. Op. cit. p. 51)

${ }^{5}$ Apesar de carregar também instrumentos como calculadoras, relógio, despertador e calendário desde o início da década de 1990.

${ }^{6}$ Músicas para celular, que podem ser compradas pela web ou pelo serviço junto à operadora. 
de acessar a web velozmente, que o aparelho passou a despertar interesse não somente como um meio de comunicação interpessoal, mas como um possível recurso de produção e distribuição de conteúdos, de status, de conexão. Tornou-se, desse modo, um fenômeno universal, que supera barreiras como classes sociais, distâncias, idiomas, idade, gênero, enfim todo e qualquer obstáculo, desde que haja a possibilidade de uma triangulação de antenas.

Os números da tabela a seguir demonstram o crescimento na aquisição dessa tecnologia ao redor do mundo entre 2004 e 2007 -- nas principais tecnologias de transmissão (especificadas mais adiante):

Tabela 1. Número de celulares no mundo a partir de 2004

\begin{tabular}{|c|c|c|c|c|c|}
\hline Em milhões & 2004 & 2005 & 2006* & 2007* & $\Delta$ Ano \\
\hline África & 78,4 & 126,3 & 193,0 & 265 & $37,3 \%$ \\
\hline \multicolumn{6}{|l|}{ Canadá e } \\
\hline E.U.A. & 52,6 & 75,2 & 92,1 & 106 & $15,1 \%$ \\
\hline \multicolumn{6}{|l|}{ América Latina } \\
\hline e Caribe & 66,7 & 137,6 & 216,9 & 297 & $36,9 \%$ \\
\hline Ásia Pacífico & 494,4 & 631,2 & 861,6 & 1.162 & $34,9 \%$ \\
\hline Eur. Oriental & 174,6 & 265,2 & 338,6 & 398 & $17,5 \%$ \\
\hline Eur. Ocidental & 361,7 & 380,6 & 435,5 & 479 & $10,0 \%$ \\
\hline Oriente Médio & 67,6 & 93,2 & 126,3 & 173 & $37,0 \%$ \\
\hline Total & 1.296 & $1.709,2$ & 2.264 & 2.881 & $27,3 \%$ \\
\hline
\end{tabular}

Fonte: GSM Association \& Wireless Inteligence

*GSM e WCDMA . Ver www.teleco.com.br

O gráfico abaixo demonstra que no final do $2^{\circ}$ trimestre de 2008 (2T08) os celulares totalizavam 3,66 bilhões (55 celulares para cada 100 hab.) ao redor do mundo, sendo $88 \%$ da família GSM/WCDMA (tecnologias explicadas mais adiante). No final de 2007 existiam 3,3 bilhões de celulares (de todas as tecnologias disponibilizadas) e uma penetração de 50 cel/100 hab. 
Gráfico 1. Evolução de celulares no mundo

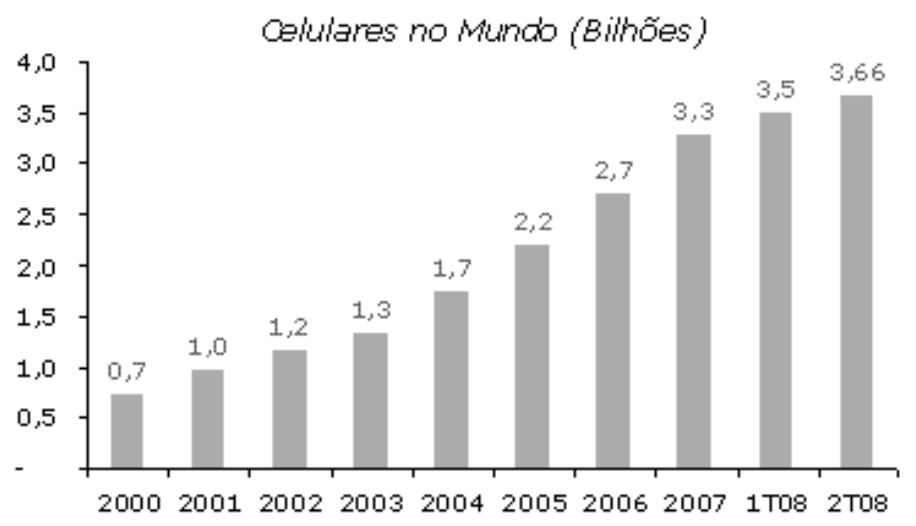

Fonte: UIT, Wireless Intelligence e GSA/Informa

Até dezembro de 2008 estima-se que quatro bilhões de celulares estarão circulando entre os seis bilhões de habitantes do planeta. Desde 2000 tem-se uma curva ascendente iniciada com 700 milhões de aparelhos e que se multiplicou constantemente desde que os países emergentes passaram a adquiri-los de maneira voraz. O Brasil aparece entre os seis maiores consumidores da tecnologia celular:

Tabela 2. Número de celulares no mundo

\begin{tabular}{|c|c|c|c|c|c|c|c|c|}
\hline Em milhõ & & & & & & & & \\
\hline País & $1 \mathrm{T07}$ & $2 T 07$ & 3T07 & 4T07 & $1 T 08$ & 2T08 & $\Delta$ Trim & $\Delta$ Ano \\
\hline 1-China & 481 & 502 & 523 & 547 & 584 & $592 * *$ & $1,4 \%$ & $17,9 \%$ \\
\hline 2-Índia** & 166 & 185 & 209 & 234 & 261 & 287 & $10,0 \%$ & $55,1 \%$ \\
\hline $3-$ USA & 237 & 243 & 248 & 255 & 259* & 262 & $1,3 \%$ & $8,0 \%$ \\
\hline 4-Rússia & 155 & 160 & 165 & 173 & 168 & 173 & $0, \%$ & $8,1 \%$ \\
\hline 5-Brasil & 102 & 107 & 113 & 121 & 126 & 133 & $5,6 \%$ & $24,3 \%$ \\
\hline 6-Japão & 102 & 103 & 104 & 105 & 107 & 108 & $0,9 \%$ & $4,9 \%$ \\
\hline
\end{tabular}

*Estimado pela Teleco; ** Referente a Maio/08

Na América Latina seis países concentram mais de $80 \%$ da quantidade de celulares adquiridos e o Brasil aparece como maior consumidor, à frente do México. 
Tabela 3. Número de celulares na América Latina

\begin{tabular}{|lllllll|}
\hline Em milhares & $1 \mathrm{~T} 07$ & 2 T07 & 3 T07 & 4T07 & 1 T08 & 2T08 \\
\hline Brasil & 102.047 & 106.556 & 112.657 & 120.891 & 125.726 & 133.083 \\
\hline México & 59.824 & 61.991 & 64.363 & 68.241 & 70.575 & 72.118 \\
\hline Argentina & 34.113 & 36.308 & 37.987 & 40.402 & 41.737 & 43.180 \\
\hline Colômbia & 30.114 & 30.511 & 31.312 & 32.300 & 35.626 & 36.816 \\
\hline Venezuela & 19.604 & 21.177 & 21.992 & 23.820 & 24.405 & 25.877 \\
\hline Chile & 12.734 & 13.054 & 13.343 & 13.955 & 13.991 & 15.169 \\
\hline \multicolumn{7}{l}{} \\
\hline
\end{tabular}

Fonte: Teleco e órgãos reguladores

www.teleco.com.br

\section{Telefone celular no Brasil: uma prática emergente}

O telefone celular chegou ao Brasil nos anos 90 [apesar de o sistema de telefonia móvel (não celular) ter sido implantado em 1972] com o objetivo de universalizar 0 acesso às telecomunicações, por meio de empresas concessionárias que operariam em um mercado concorrencial e competitivo graças ao processo de privatização das telecomunicações no país. Em setembro de 2008 o país ultrapassou 136 milhões de telefones celulares, sendo 110 milhões de pré-pagos e 26 milhões de pós-pagos (numa proporção de $81 \%$ contra 19\%) segundo a Anatel -- Agência Nacional de Telecomunicações.

O celular, dessa forma, vai se tornando o principal aparelho da telefonia na casa dos brasileiros: segundo os dados da Pesquisa Nacional por Amostra de Domicílios (Pnad) divulgada pelo Instituto Brasileiro de Geografia e Estatística (IBGE),

o número de domicílios que contam com telefones celulares cresceu, mas o maior crescimento foi observado entre os domicílios que possuem somente telefone celular, sem a presença do telefone fixo. Em 2006 as casas que contavam com telefone celular representavam $63,6 \%$ e as que possuiam apenas o telefone celular 27,7\% e em 2007 este número subiu para $67,7 \%$ nas casas com telefones celulares e $31,6 \%$ onde se tem apenas o telefone celular ${ }^{7}$.

\footnotetext{
${ }^{7}$ (http://www.teleco.com.br. Acessado no dia 23 de setembro de 2008)
} 
Tabela 4. Percentual de domicilios com aparelhos comunicacionais

\begin{tabular}{|l|c|c|c|c|}
\hline PNAD (IBGE) & $\mathbf{2 0 0 4}$ & $\mathbf{2 0 0 5}$ & $\mathbf{2 0 0 6}$ & $\mathbf{2 0 0 7}$ \\
\hline Rádio & $87,80 \%$ & $88,00 \%$ & $87,90 \%$ & $88,10 \%$ \\
\hline Televisão & $90,30 \%$ & $91,40 \%$ & $93,00 \%$ & $94,50 \%$ \\
\hline Telefone & $65,40 \%$ & $71,60 \%$ & $74,50 \%$ & $77,00 \%$ \\
\hline (Fixo ou Celular) & $16,30 \%$ & $18,60 \%$ & $22,10 \%$ & $26,60 \%$ \\
\hline Microcomputador & $12,20 \%$ & $13,70 \%$ & $16,90 \%$ & $20,20 \%$ \\
\hline $\begin{array}{l}\text { Microcomputador com acesso } \\
\text { à Internet }\end{array}$ & 51.753 & 53.053 & 54.610 & 56.344 \\
\hline Total de Domicilios (milhares)
\end{tabular}

Fonte: IBGE

Tabela 5. Celulares no Brasil em Ago/08

\begin{tabular}{|lllll|}
\hline & Ago/07 & Dez/07 & Jul/08 & Ago/08 \\
\hline Celulares & 110.929 .896 & 120.980 .103 & 135.330 .980 & 136.420 .899 \\
\hline Pré-pago & $80,34 \%$ & $80,66 \%$ & $80,99 \%$ & $81,10 \%$ \\
\hline Densidade & 58,57 & 63,59 & $70,57 \%$ & 72,09 \\
\hline Cresc. mês & 2.410 .232 & 4.666 .276 & 2.162 .434 & 3.089 .919 \\
\hline & $2,22 \%$ & $4,01 \%$ & $1,62 \%$ & $2,3 \%$ \\
\hline Cresc. ano & 11.011 .275 & 21.061 .482 & 14.350 .877 & 17.440 .796 \\
\hline & $11,02 \%$ & $21,08 \%$ & $11,86 \%$ & $14,42 \%$ \\
\hline $\begin{array}{l}\text { Cresc. em } \\
1 \text { ano }\end{array}$ & 16.024 .898 & 21.061 .482 & 26.811 .316 & 27.491 .003 \\
\hline & $16,89 \%$ & $21,08 \%$ & $24,71 \%$ & $24,78 \%$ \\
\hline
\end{tabular}

Fonte: ANATEL

Nota: celulares ativos na operadora. Densidade calculada com a projeção de população do IBGE para o mês respectivo. *Com a nova estimativa de população do IBGE para Jul/08 a densidade passou a ser 71,37 cel/100 hab.

Os domicílios que possuem somente celular é três vezes maior que o de domicílios que possuem somente telefone fixo. O número de celulares nos lares cresce a uma velocidade maior que a televisão e o rádio já há um bom tempo. O Brasil possui no terceiro trimestre de 2008, segundo a Anatel, 136,4 milhões ${ }^{8}$, uma densidade de aproximadamente 71 celulares para cada 100 habitantes, somente nos últimos 12 meses foram adquiridos 27,5 milhões de aparelhos no país.

\section{Tecnologias de transmissão em constante atualização}

Anteriormente foram citadas siglas que indicam o sistema de transmissão da tecnologia celular. Esses sistemas foram os desenvolvidos em

\footnotetext{
${ }^{8}$ Em outubro, a Teleco (www.teleco.com.br) atualiza o número de celulares no país para 141, 4 milhões.
} 
distintas regiões do mundo (EUA, Europa e Ásia) para possibilitar a transmissão de dados (desde o modelo analógico até o digital) e a padronização por operadoras. Os sistemas mais comuns são:

Tabela 6. Sistemas de transmissão de dados por celular

AMPS: Advanced Mobile Phone Sistem, uma das pioneiras na telefonia móvel analógica entre aparelhos celulares e não via rádio (PTT);

TDMA: Time Division Multiple Access, um sistema digital que divide um único canal em vários espaços de tempo, permitindo que cada usuário utilize um desses espaços, tornando necessária a compressão de voz, que fez com que esse sistema tivesse baixa qualidade;

GSM: Global System for Mobile Communications, tecnologia européia das mais usadas no mundo. Apesar de baseado na divisão de tempo, como o TDMA, permite a troca de transmissão de dados através dos cartões de memória $\operatorname{SIM}^{9}$, bem como o acesso rápido a serviços de protocolos sem fio (WAP- Wireless Application Protocol) e à web, através do acelerador de velocidade de transmissão de dados GPRS (General Packet Radio Services);

CDMA: Code Division Multiple Access, muito popular no mercado asiático, disputa mercado com a tecnologia GSM e apresenta vantagens semelhantes ao sistema europeu. Surge no Brasil em 2003, pela Vivo, a maior operadora de celular do país. Transforma a voz ou os dados em sinais de rádio codificados posteriormente decodificados nas antenas para a recepção;

O WCDMA, a terceira geração de telefones celulares que começam a despontar no Brasil permite a convergência de dados, voz e imagens, com informações em alta velocidade (2mbps).

Fonte: www.teleco.com.br (acessado em 07/08/2008)

Para complementar, as gerações de sistemas de telefonia celular são divididas em:

1G- Sistemas analógicos (AMPS);

9 Subscriber Identity Module: cartão de dados para telecomunicações em GSM, com um microprocessador dotado de portas de entrada e saída, memórias e sistema operacional, com mecanismos de segurança incorporados (MANTOVANI, ibid. p. 54, 55). 
2G- Sistemas digitais como o GSM, CDMA ou TDMA;

2,5G- Sistemas celulares que oferecem serviços de dados por pacotes em até $144 \mathrm{kbps}$ (GPRS e CDMA). Com velocidade média de $50 \mathrm{kbps}$ são intermediários entre os $2 \mathrm{G}$ e $3 \mathrm{G}$;

3G- Sistemas que permitem a convergência de dados, voz e imagem, em alta velocidade, ampliando os serviços e aplicativos disponíveis (transmissão de fotos, vídeos e navegação na web ${ }^{10}$ ).

$\mathrm{Na}$ tabela a seguir apresenta-se o número de celulares por Tecnologia até agosto de 2008:

Tabela 7. Tecnologias no Brasil

\begin{tabular}{|c|c|c|c|c|c|}
\hline \multirow[t]{2}{*}{ Tecn. } & \multirow[t]{2}{*}{$\begin{array}{l}\text { Dez. } \\
2007\end{array}$} & \multicolumn{3}{|c|}{ Agosto 2008} & \multirow[b]{2}{*}{ Cresc. Ano } \\
\hline & & No Celulares & & Cresc. mês & \\
\hline AMPS & 15.581 & 12.491 & $0,01 \%$ & 2.077 & $-19,8 \%$ \\
\hline TDMA & 5.157 .187 & 2.643 .005 & $1,91 \%$ & -215.364 & $-48,8 \%$ \\
\hline CDMA & 20.881 .790 & 15.055 .573 & $10,88 \%$ & -605.008 & $-27,9 \%$ \\
\hline GSM & 94.925 .545 & 119.217 .720 & $86,13 \%$ & 3.731 .226 & $25,6 \%$ \\
\hline WCDMA & - & 974.901 & $0,70 \%$ & 198.963 & \\
\hline $\begin{array}{l}\text { CDMA } \\
2000\end{array}$ & - & 517.209 & $0,37 \%$ & -21.975 & \\
\hline Total & 120.980 .103 & 136.420 .899 & $100 \%$ & 3.089 .919 & $14,4 \%$ \\
\hline
\end{tabular}

Fonte: www.teleco.com.br (acessado em 12/08/2008)

Percebe-se, portanto, uma multiplicação constante de telefones celulares, um fenômeno contemporâneo expressivo e que envolve o mercado e seus mecanismos de geração de demandas; envolve o Estado, permissionário para que empresas privadas operem a telefonia em seu território; apresenta constantes desenvolvimentos tecnológicos e suas renovações; e manifesta a necessidade de comunicação (no sentido lato do termo - envolvendo desde a linguagem, passando pelo processo de cultura, até as relações políticas nela contidas) do indivíduo.

\footnotetext{
${ }^{10} \mathrm{Web}$ (rede) é a denominação aqui utilizada, e ao longo de toda a presente dissertação, para se referir também à internet.
} 


\section{Os instrumentos celulares e razões de usos}

Com a redução do tamanho dos aparelhos e o custo acessível o celular popularizou-se pelo serviço de voz, pela possibilidade de envio e recebimento de mensagens de texto; posteriormente os jogos, as telas coloridas e os ringtones passaram a fazer parte da rotina dos usuários. Mas é com a hibridação (a partir daqui utiliza-se também o termo híbrido - no sentido de múltiplas funções -- para referir-se ao telefone celular) as câmeras fotográficas, filmadoras, gravadores de áudio e podcasts, com o poder de acessar a web velozmente e de compartilhar conteúdos que o aparelho passou a despertar interesse não somente como um meio de comunicação interpessoal, mas como recurso de produção e distribuição de conteúdos, de status, de conexão, de inclusão. Ele tornou-se um mediador importante no universo simbólico de seu usuário. Este último passa, então, a uma categoria também híbrida na qual se torna receptor/emissor/produtor/distribuidor (cabe ressaltar ainda o papel de consumidor) de conteúdos a partir de uma tecnologia digital-móvel-portátilhíbrida (o mobile ${ }^{11}$ ).

Em uma análise da primeira metade dos anos 2000, Mantovani aponta quatro tipos de uso significativos a partir dos mobiles: a segurança atravessada pela violência urbana, pela vigilância de pessoas próximas e para situações de socorro; a coordenação - das atividades rotineiras, como por exemplo marcar ou desmarcar "encontros durante congestionamentos "12"; a expressividade e a representação do eu - em outras palavras a possibilidade de interação com outras pessoas a qualquer momento ou situação; e o consumo de informações - a aquisição de ringtones ou de papéis de parede tornou-se uma forma de personalizar (limitadamente ao que é oferecido) o aparelho e seus usos, posicionando o usuário em determinado "contexto social e cultural."

Ao redor do mundo os usos do celular se disseminam, e se adéquam às culturas dos diversos países que adotam a tecnologia de maneira intensa para os mais variados fins: finlandeses explicam seu uso pela necessidade de estar

\footnotetext{
${ }^{11}$ Do inglês e do francês, ambos significam mobilidade -- outro termo para denominar o telefone celular neste estudo.

${ }^{12}$ MANTOVANI, ibid. p, 58.
} 
sempre disponíveis ${ }^{13}$; japoneses usam o portátil para ações que vão desde transações bancárias até a coordenação remota de ações domésticas; alemães, ingleses e franceses jogam botfighters e mogi ${ }^{14}$ e, por vezes, no Brasil é possível encontrar manifestações como os flash mobs ${ }^{15}$.

Mais recentemente, com a possibilidade de compartilhar informação através de mecanismos anexados à paisagem urbana (como o blue tooth ou etiquetas que emitem informação de rádio -- $\mathrm{RFID}^{16}$ ) em zonas Wi-Fi, renomeiam-se espaços, reconfiguram-se temporalidades, incrementam-se ações.

\section{Espaços híbridos e territórios informacionais: objeto de estudo}

O mobile se agrega então ao universo de "mídia (sic) locativa" que surge a partir de espaços com mecanismos digitais adaptados. Estes permitem o "monitoramento, a vigilância, mapeamento, geoprocessamento (GIS), localização, anotações ou jogos", e que, segundo Lemos, fazem com que "os lugares/objetos passem a dialogar com dispositivos informacionais, enviando, coletando e processando dados a partir de uma relação estreita entre informação digital, localização e artefatos digitais móveis ${ }^{18 "}$.

Isso acarreta diferentes funções aos aparatos comunicacionais inseridos no urbano. Mídias locativas analógicas são comuns: placas de hotéis, de restaurantes ou pizzarias. Quando um mecanismo digital é agregado a essas placas, por exemplo, elas passam a enviar informações digitais como

${ }^{13}$ PURO, 2002. Apud MANTOVANI, 2006, p. 60.

${ }^{14}$ Através deles lugares,objetos ou pessoas devem ser descobertos dentro da cidade, transformando os espaços em ambientes de multiusuários.

${ }^{15}$ Movimentos em que dezenas, centenas e, em alguns casos, milhares de pessoas com telefones celulares se agrupam e fazem uma manifestação, em alguns casos chega a arregimentar pessoas para passeatas de cunho político (ver SOUZA E SILVA in: ARAÚJO, D. C. Op. cit. p. 33)

${ }^{16}$ Bluetooth é uma forma de conexão sem fio com alcance de 10 metros (http://www.bluetooth.org). Sobre RFID ver: http://www. rfidjournal.com - e o protocolo Wi-Fi possibilita acesso à web por ondas de rádio (http://www.wi-fi.org). (LEMOS, André. Mídia locativa e territórios informacionais, in Carnet de notes, http://www.facom.ufba.br/ciberpesquisa/andrelemos/locativa.pdf. Acesso em 20 de janeiro de 2007).

${ }^{17}$ Mídia locativa são dispositivos informacionais digitais cujo conteúdo da informação está diretamente ligado a uma localidade para serem acessados por GPS, celulares, ou etiquetas, por exemplo. (LEMOS, A. Ibidem.)

È necessário também indicar que neste trabalho não se utiliza a palavra mídia (adotada na língua portuguesa do Brasil). Usa-se o termo masculino plural media (do latim, que se pronuncia mídia), para indicar um conjunto de meios de comunicação, e medium (masculino singular) quando indicar apenas um meio (TRIVINHO, E. A dromocracia cibercultural: lógica da vida humana na civilização mediática avançada. São Paulo: Paulus, 2007, p. 19) .

${ }^{18}$ LEMOS, A. Op. cit. 
promoções, lotação, menu etc. O diálogo entre tecnologias é hoje uma realidade e o celular é o mecanismo de acesso mais presente na vida diária. "O projeto undersound alia música, compartilhamento e mobilidade no metrô de Londres", explica Lemos, e "permite que os usuários façam uploads de músicas para o sistema e possam baixar músicas deixadas por outros usuários do metrô, com identificação das estações ${ }^{19}$."

Graças a esses mecanismos percebe-se não somente a anexação da tecnologia digital à cidade, mas sua extensão para outras dimensões temporais-espaciais, multiplicando-a infinitamente e portabilizando-a junto ao corpo através do aparelho celular, que passa ao status de prótese $e^{20}$ para que se efetivem essas relações entre sistemas (rádio e TV se reproduzem no celular, conteúdos musicais são depositados no podcast a ele hibridado). "Se as cidades da era industrial constituem sua urbanidade a partir do papel social e político das mídias (sic) de massa, as cibercidades contemporâneas estão constituindo sua urbanidade a partir de uma interação intensa (e tensa) entre mídias de função massiva e as novas mídias de funções pós-massivas ${ }^{21}$."

No entanto são tímidas e localizadas as práticas sociais e políticas através dos territórios informacionais ${ }^{22}$ a partir desses "media pós-massivos". Alguns fenômenos, entretanto, mereçam destaque, como a mobilização social (smart mobs) para "coordenar atividades corriqueiras e políticas", que através das redes de comunicação pelo celular levaram à destituição do primeiroministro tailandês, Thaksin Shinawatra, em 2006. Outro exemplo é a troca de impressões sobre ambientes da cidade via e-mail, por celular, com intuito de possibilitar leituras livres dos espaços públicos. Lemos compara algumas dessas ações às práticas de ocupação de espaços da cidade com arte (através

\footnotetext{
${ }^{19}$ LEMOS, A. Ibidem.

${ }^{20}$ Conforme Santaella, prótese é "uma parte, um suplemento do corpo humano que não é complexamente integrada, nem autônoma". (SANTAELLA, Lucia. Culturas e artes do pós-humano: da cultura das mídias à cibercultura. São Paulo: Paulus, 2003, p. 201)

${ }^{21}$ Para Lemos, os media de função pós-massiva "funcionam a partir de redes telemáticas em que qualquer um pode produzir informação 'liberando' o pólo da emissão, sem necessariamente haver empresas e conglomerados econômicos por trás”. (LEMOS, André. Cidade e mobilidade: telefones celulares, funções pós-massivas e territórios informacionais. In: MATRIZes. Revista do Programa de Pós-Graduação em Ciências da Comunicação da Universidade de São Paulo. Ano 1, n. 1 (jul - dez 2007) - São Paulo: ECA/USP, 2007, p. 125)

${ }^{22}$ Para Lemos, territórios informacionais são "áreas de controle do fluxo informacional digital em uma zona de intersecção entre o ciberespaço e o espaço urbano”. (LEMOS, A. Idem, p. 128)
} 
de performances, leituras e exposições), como as realizadas pelos dadaístas, surrealistas e situacionistas na segunda metade do século 20.

Para Souza e Silva, essa ampliação do espaço forma uma realidade híbrida: "mistura de práticas sociais que ocorrem simultaneamente em espaços físicos e digitais, adicionada à mobilidade". Isto se dá em um espaço híbrido, "criado pela conexão de mobilidade e comunicação, e materializado por redes sociais desenvolvidas simultaneamente em espaços físicos e digitais ${ }^{23 " .}$.

É relevante (tanto quanto complementa a definição de espaço para a compreensão de sua dimensionalidade) definir o espaço de fluxos como "a organização material de práticas sociais temporalmente compartilhadas que funcionam através de fluxos ${ }^{24 ",}$ através dos quais interagem em tempo real "atores sociais distribuídos", complementa Stalder ${ }^{25}$. Para Souza e Silva o espaço é "produzido por e embutido em práticas sociais, nas quais a infraestrutura de suporte é composta por uma rede de tecnologias móveis ${ }^{26 "}$. O espaço ao qual este estudo se refere é físico (no local e através de fluxos) e abstrato (no simbólico), caracterizado pelas práticas que o tornam existente; um espaço que se concretiza também na mobilidade.

\subsection{Simbolismo celular: a pertinência cultural do seu uso}

Elege-se, pois, o tema do simbolismo presente no uso do celular como objeto que centraliza as preocupações do presente estudo. Sua pertinência é a atualidade e originalidade, posto que desloca o olhar do aparelho portátil (de suas atualizações ou de uma relação unicamente espacial) e foca especificamente a produção simbólica possível de ser verificada pelas ações do usuário que se apresenta, hoje, em papéis sociais mesclados, como consumidor de informação, cidadão universal, produtor de conteúdos.

Acredita-se que essas ações refletem os ambientes urbanos, mais precisamente a esfera local e, sendo assim, representam no sentir e no agir durante relações sociais ou em práticas culturais um abismo de desigualdades

\footnotetext{
${ }^{23}$ SOUZA E SILVA, Adriana. Do ciber ao híbrido: tecnologias móveis como interfaces de espaços híbridos. In: ARAÚJO, Denise Correa (org.). Imagem (ir)realidade: comunicação e cibermídia. Porto Alegre: Sulina, 2006, p. 31,32.

${ }^{24}$ CASTELLS, Manuel. The rise of the network society. Oxford: Malden, MA: Blackwell Publishers, 2000, p. 442, apud SOUZA E SILVA, op. cit. p 42.

${ }^{25}$ In: SOUZA E SILVA, A. Op. cit. p. 42

${ }^{26}$ Ibidem, p. 43.
} 
(econômica, cultural e social), dissimuladas pelos apetrechos do simulacro tecnológico criado também a partir da prótese celular.

À integração das diferenças, à convivência com conteúdos mediáticos produzidos para compor o universo simbólico das massas, à transnacionalização de culturas, somam-se agora, como nunca, as tecnologias. As estruturas (físicas e ideológicas) a partir das quais surge o pensamento sociológico moderno dão lugar (ou convivem com), nesse início de século 21 , a outra esfera - a da informação -- na qual se efetivam todas as ações representativas dos sistemas econômico, social e político do mundo físico, e do universo cibernético, mediático e simbólico. Com efeito, todas as práticas e significados do mundo de hoje acontecem inevitavelmente pelo, entre, ou por causa do universo digital. A esse fenômeno denomina-se cibercultura ${ }^{27}$.

Com múltiplos aparelhos convergentes ao telefone celular, têm-se pela primeira vez um contexto de tantas máquinas em um mesmo tempo, anexadas ao corpo $^{28}$ - e, cabe complementar, em deslocamento e disponível para todos. Essa prótese com a gama mediática nela hibridada, não somente acelera/agiliza contatos interpessoais e grupais através de redes comunicacionais, como permite ressignificar o cotidiano ${ }^{29}$ e a relação do que é público e privado; caracteriza prestígio estamental ${ }^{30}$, estende os sentidos do corpo (bem como a ele anexa meios massivos e ferramentas de produção áudio-visual), intensifica o sentimento de pertença ${ }^{31}$, a sensação de

\footnotetext{
${ }^{27}$ Ver outros conceitos em TRIVINHO, Eugênio. Dromocracia cibercultural: lógica da vida humana na civilização mediática avançada. São Paulo: Paulus, 2007.

28 "O objeto tecnológico", aponta Trivinho, "de extensão do ente humano, passou a ser vetor de processos, ocupando por isso o centro da cena, enquanto o ente humano (...) acabou por figurar na história como um de seus anexos". (TRIVINHO, Eugênio. O mal-estar da teoria: a condição crítica na sociedade tecnológica atual. Rio de Janeiro: Quartet, 2001, p.83)

${ }^{29}$ Têm-se o cotidiano aqui como práticas e modos de simbolização que permitem ao homem alterar "os objetos e os códigos" e dessa forma" se reapropria do espaço e do usos ao seu jeito." (CERTEAU, Michel de. A invenção do cotidiano. Petrópolis, RJ: Vozes, 2001)

${ }^{30}$ Não somente a questão de status, mas estamental no sentido weberiano do termo: "denominamos situação estamental um privilégio típico positivo ou negativo quanto à consideração social, eficazmente reivindicado." (WEBER, Max. Economia e sociedade. Brasília, DF: Editora Universidade de Brasília: São Paulo: Imprensa Oficial do Estado de São Paulo, 1999, p. 202)

${ }^{31} \mathrm{O}$ pertencimento hoje supera o desejo ou a reivindicação da inclusão ou do acesso. O que se quer é participar e de definir "aquilo no qual queremos ser incluídos, a invenção de uma nova sociedade". DANIGNO, Evelina. Os movimentos sociais e a emergência de uma nova noção de cidadania. In: Anos 90: política e sociedade no Brasil. São Paulo: Brasiliense, 2004, p.109.
} 
proximidade e de segurança ${ }^{32}$, enfim, medeia elementos (físicos e abstratos) que compõem a sociedade ${ }^{33}$.

Contudo, esse pequeno híbrido, em seus usos banalizados, expõe paradoxalmente o surgimento de distintos modos de inclusão, e um modelo rearranjado de exclusão, da manutenção da solidão diante da multidão, de subordinação ao poder econômico e, principalmente, de práticas de violência (física e simbólica) que se desenvolvem a partir de seus usos; ações estas despercebidas pelos usuários.

Ainda que de modo simbólico, acredita-se, o celular reforça uma desigualdade vinculada à má distribuição da renda de nações e de pessoas em relação aos estratos populacionais. Nesses ambientes economicamente e simbolicamente desiguais existem outras variáveis relevantes para suas concretizações:

Constituem também fatores que incidem de maneira importante na distribuição de renda a posição do emprego (nos setores formal e informal da economia), as oportunidades educativas, as diferenças de instrução dos estratos populacionais e de a cesso aos serviços básicos de saúde, as taxas demográficas, o número de filhos por família $e$ as diferenças de gênero. (DÍAZ, Laura Mota, in: CIMADAMORE, Alberto e CATTANI, Antônio David, 2008, p. 128, 129)

Acredita-se, portanto, que os significados das tendências de usos do celular e da relação dessas tendências com a condição sócio-econômica, cultural e de prestígio social a partir de espaços urbanos (estes representantes de esferas sociais desiguais) demonstram que o telefone móvel portátil não somente participa de cotidianos. Reforça hábitos, laços sociais e culturais e assim pode transformar-se em um objeto reprodutor de condições já impostas, podendo agregar a elas valores democráticos ou de igualdade, bem como de diferenças e desigualdades.

${ }^{32}$ Objetos viram fetiche, objeto de devoção "verbalmente silenciosa, mas emocionalmente intensa". (CERTEAU, M. Op. cit. p.84)

${ }^{33}$ Visto que a própria sociedade, aponta Simmel, "significa interação entre indivíduos". (SIMMEL, Georg. Questões fundamentais da sociologia. Rio de Janeiro: Jorge Zahar, 2006, p. 59) 


\section{O celular e as expressões da desigualdade no seu uso}

Há, portanto, um paradoxo: por um lado a prótese celular inova ao gerar necessidades (ao menos de manutenção da tecnologia para a comunicação); ao saciar efemeramente o prazer $^{34}$ (quando permite a audição de músicas, os jogos, e a proximidade com o outro); ao intensificar sensações de segurança, de inclusão e de conexão com o mundo físico e com o digital. Por outro lado o telefone celular reflete também inúmeras formas de exclusão (àqueles que não detêm capital - econômico e simbólico para servir-se dos serviços pagos), de desconexão (aos que não possuem tecnologias compatíveis com o grupo) e de diferenças (é-se agora também um desconectado, portanto excluído de relações sociais e comunicacionais mediadas pelo mobile).

Está-se diante de um meio de comunicação ímpar, através do qual as diferenças ${ }^{35}$ são imaginadas ou expressadas ágil, veloz e intensamente. Desse modo, reconfiguram-se sentidos de igualdade e de desigualdade (definidos no capítulo 2) - deslocados do processo econômico e inseridos agora no universo social, político, cultural e comunicacional - graças ao enredamento da sociedade em tecnologias do tempo real, em especial à protetização dos media ao corpo.

O presente estudo trabalha com a noção de práticas culturais e sociais manifestas a partir dos usos do telefone celular e de seus híbridos. Tem como objetivo geral refletir sobre as desigualdades simbolizadas com a incorporação desse aparelho móvel ao cotidiano; e, em conseqüência, atualizar bibliograficamente as tecnologias e os indicadores estatísticos a ele referentes. Especificamente, quer-se verificar as tendências para as quais os usos do objeto celular apontam -- em ambientes representantes de diferenças - e, a partir desse levantamento, realizar uma leitura dos significados das práticas sociais representadas através dessa tecnologia (pertença, prestígio social, exposição de si, vigilância e outros capazes de compor desigualdades).

A contemporaneidade é marcada pela carga infindável de informação disponibilizada através de redes digitais integradas, que proporcionam a

\footnotetext{
${ }^{34}$ Ver GODOI, Christian. À luz com as massas mediáticas: o prazer como mediação no contexto da recepção. In: Os sentidos da violência. Santos, SP: Realejo Edições, 2008.

${ }^{35}$ Segundo Barra um "ingrediente constitutivo da cultura européia, invenção de um alter ego, de um 'selvagem artificial', para reservar aos europeus o lugar civilizado. (BARRA, in CANCLINI, Néstor Garcia. Consumidores e cidadãos. Rio de Janeiro: UFRJ, 2006, p. 266)
} 
convergência de mecanismos de produção simbólica, de linguagens (audiovisuais) que estandardizam produtos mediáticos. Contudo, permanece ainda uma lacuna nos estudos de comunicação quando na esfera da recepção, ou melhor, na simbolização processada através dos usos e reproduzida nas práticas sociais.

Essa lacuna torna o aparelho celular um objeto relevante, primeiro pela sua presença constante entre parte representativa das sociedades ${ }^{36}$, nas mãos de tantos diferentes. $E$, conseqüentemente, pelo acesso à variedade de tecnologias e de conteúdos simbólicos, protetizando soluções localizadas para desejos e necessidades, o aparelho móvel aparece, também, como um instrumento aparentemente democrático.

O telefone celular faz-se presente como extensão do espaço físico, do cibercultural e da produção simbólica entre categorias sociais antagônicas proprietárias de tecnologias parecidas. Em outras palavras, dão-se, na atualidade, oportunidades tecnológicas semelhantes a uma gama extensa de diferenças sociais.

É a partir do panorama posto que se pergunta, como problemática para o presente estudo: podem as tendências das práticas efetivadas a partir do celular representar ecos de desigualdades? E mais: as razões de classe, estrato, ou ambiente, podem fazer com hajam usos equivalentes do telefone móvel entre grupos de representação advindos dos lugares em que se colocam na posição de igualdade?

\section{Indicadores em construção}

Acredita-se que os sistemas simbólicos, como proposto por Bourdieu ${ }^{37}$, por se tratarem de "instrumentos de conhecimento e de comunicação, só podem exercer um poder estruturante porque são estruturados ${ }^{38 " . ~ E ~ e ́ ~ n o ~}$ campo de produção simbólica que se dá uma "luta simbólica entre as classes"

36 Cabe, neste momento, uma posição quanto ao que significam comunidade e sociedade. Weber denomina "comunidade a uma relação social quando a atitude na ação social (...) inspira-se no sentimento subjetivo (afetivo ou tradicional) dos partícipes da constituição de um todo (...). Chamamos sociedades a uma relação social quando a atitude na ação social inspira-se numa compensação de interesses por motivos racionais (de fins e de valores) ou também numa união de interesses com intensa motivação (...)" (WEBER, 1973, p. 140. In: SOUSA, Mauro Wilton de. Recepção mediática e espaço público: novos olhares. São Paulo: Paulinas, 2007, p. 218.

${ }^{37}$ Ver conceitos de estruturas estruturantes e estruturadas no capítulo III.

${ }^{38}$ BOURDIEU, Pierre. O poder simbólico. Rio de Janeiro: Bertrand Brasil, 2007, p.9. 
(aqui cabe o conceito de classe proposto no capítulo II - que apresenta um deslocamento da questão ideológica marxista, a qual aponta as classes a partir da esfera econômica).

Entretanto, ao contrário do que propõe o sociólogo francês, o simbólico não serve somente aos propósitos de classes dominantes, como será mostrado adiante. Crê-se em uma constante negociação, em uma troca de conteúdos -em especial pelo enredamento através dos meios de comunicação -- que permite o trânsito de sentidos entre as diferenças.

Para o presente estudo o campo simbólico é produzido por inúmeros fatores ligados à cultura, ao econômico, às relações sociais e políticas, de interesse entre as classes (grupos, estamentos ou estratos sociais), e essas relações, apesar de desiguais, tensionam-se incessantemente.

A hipótese deste trabalho, portanto, é a de que as ações efetivadas através do celular são a manifestação simbólica de espaços sociais de desigualdade. O aparelho, destarte, é um reprodutor não somente dos desejos, das necessidades e das diferenças de cada grupo, mas é principalmente um instrumento de possibilidades que permite aos diferentes se posicionarem diante do outro (economicamente, socialmente, culturalmente).

Para esta dissertação, apesar de o celular, e todas as possibilidades nele contidas (seja na esfera tecnológica, seja na simbólica), fornecerem caminhos para que se reduzam as distâncias entre estratos sociais distintos (em especial na questão comunicacional, esfera na qual tanto se discursa sobre inclusão digital), as desigualdades econômicas, culturais e comunicacionais se mantém pelas limitações de simbolização às quais os grupos estão vinculados.

Assim, buscar-se-á que o celular pode ser, também, um modo de reproduzir as diferenças, e com isso as deficiências (relativas) de determinados grupos frente a outros. Desse modo ficam explícitas desigualdades que transitam paralelamente às oportunidades dadas pela cibercultura. Por vezes as ações efetivadas pelos instrumentos móveis representam, silenciosamente, a reivindicação pela redução dessas desigualdades. Daí a tensão aparente com o uso do mobile: as ações tornam-se políticas (ainda que inconscientemente) em oposição à reprodução do local de significação. 
As desigualdades, como expressão e significação da manutenção das diferenças, recebem nuances distintas em esferas culturais, políticas ou sociais. Para Elias, "as desigualdades entre grupos e indivíduos estão entre as marcas distintivas recorrentes das sociedades humanas" e a trajetória para a compreensão desse fenômeno está ainda em curso. "Mas", continua o sociólogo alemão, "não deixa de ter importância, para a compreensão das sociedades humanas, examinar e questionar a reivindicação, feita por algumas delas, de representarem um estado de igualdade ${ }^{39 "}$.

Deve-se ater ao fato ainda de que os sentidos de desigualdade convergem como nunca para os media (de massa ou digitais), pois "os meios

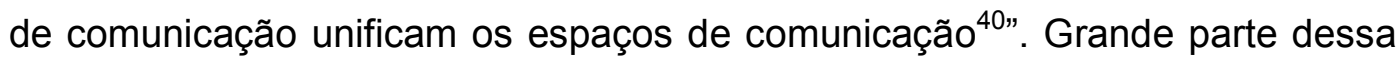
unificação, determinada verticalmente há tempos pelos meios de massa TV e rádio, agora aparece horizontalizada com a expansão da internet e do uso do celular, com destaque para a probabilidade do deslocamento. Ao possibilitar o pertencimento social que "se realiza por meio da comunicação mediatizada também pelo conflito, pela tensão nesse processo de interesses, a um só tempo sociais e políticos", conforme Sousa ${ }^{41}$, evidencia-se a comunicação como "componente da gestão social".

O aparelho celular, pelo acesso e uso comum, simboliza pretensamente a semelhança, mas a desigualdade se manifesta pelo ambiente que forma o usuário. As igualdades estão na necessidade de comunicação, no uso generalizado do celular como instrumento de relacionamento; as desigualdades estão nos modos de representar presentes nesses usos.

Desse modo, o capítulo 1 da presente dissertação atualiza dados estatísticos disponíveis sobre tecnologias e distribuição do aparelho celular no mundo, até o final de 2008. Bem como realiza a introdução à pesquisa proposta, disponibilizando um panorama do uso do celular ao redor do mundo e as possibilidades relacionais que ele proporciona.

O capítulo 2 não somente conceitua desigualdade, como relê a questão das diferenças e o modo pelo qual a simbolização, a partir desses elementos,

\footnotetext{
${ }^{39}$ ELIAS, Norbert, SCOTSON, John L. Os estabelecidos e os outsiders: sociologia das relações de poder a partir de uma pequena comunidade. Rio de Janeiro: Jorge Zahar, 2000, p. 199.

${ }^{40}$ SORJ, Bernardo e MARTUCCELLI, Danilo. O desafio latino-americano: coesão social e democracia. Rio de Janeiro: Civilização Brasileira, 2008, p. 64.

${ }^{41}$ SOUSA, M. W. Op. cit. p. 238.
} 
interfere na produção e reprodução de sentidos. Nessa etapa, também discutese a importância das possibilidades de acesso e a democratização da comunicação a partir do telefone celular, e deste como reprodutor de desigualdade.

No terceiro capítulo discutem-se os significados do uso do celular, não só através de elementos conceituais de simbolização. Apresenta-se uma breve estruturação das práticas, que apontam para uma equivalência no acesso tecnológico a grupos distintos, mas que obliteram uma desigualdade estrutural perceptível nos usos.

O capítulo 4 demonstra, bibliograficamente e através de estudos de caso, a ocorrência paradoxal que surge com o uso do mobile: uma inclusão que aparece com a tecnologia, em tensão com a desigualdade social reproduzida pelo significado das ações no uso do telefone celular.

\section{Metodologia}

Poucos autores versam sobre essa temática ${ }^{42}$ através da perspectiva que aqui se aborda ${ }^{43}$, voltada para o estudo de práticas sociais reconfiguradas com a presença da microtecnologia-móvel-celular. Esta é, portanto, uma investigação pioneira que se torna necessária por envolver a interpretação dos resultados da observação (empírica) de ações efetivadas no uso do telefone celular. Crê-se estar contribuindo para a manutenção da crítica teórica permitindo, a partir de um processo dialético, o incentivo a novas perspectivas para o estudo da relação entre o homem e a máquina digital-protética-móvel na construção do pensamento.

A multiplicidade de elementos enredados nas variáveis (desigualdade, telefone celular e práticas sociais) é apresentada sob a perspectiva das Ciências da Comunicação, carregada, portanto, de conceitos advindos da linguagem, filosofia, sociologia, antropologia e da psicanálise, contudo, dado o contexto complexo de um mundo interconectado e ao desenvolvimento de

\footnotetext{
${ }^{42}$ Os textos mais relevantes encontram-se em Lemos:

In Carnet de Notes, HTTP://www.facom.ufba.br/ciberpesquisa/andrelemos/locativa.pdf. ou em MANTOVANI, C. M. C. A. Op. cit.

43 Apesar de Sorj ter utilizado algumas das características sociais do aparato celular, do modo como é abordado aqui, mas sem estabelecer o telefone como objeto de seu trabalho. O autor prima pela mudanças sociais contemporâneas, incluindo as tecnologias. (SORJ, Bernardo e MARTUCCELLI, Danilo. $O$ desafio latino-americano: coesão social e democracia. Rio de Janeiro: Civilização Brasileira, 2008.)
} 
outras áreas do conhecimento e suas inevitáveis imbricações com os estudos comunicacionais, não se excluem possíveis abordagens intertransdisciplinares sobre Ciências da Informação, neurociências ou economia.

Nada impede ainda que outro movimento se processe, como explica Merton: o de acumulação dos resultados científicos. Toma-se aí a questão da horizontalidade no processo científico, para que se possam oferecer diversidades como alicerces para a construção de um edifício de conhecimento. "Esta fertilização cruzada produz um híbrido vigoroso, com as categorias teóricas interessantes de uma e as técnicas de investigação empírica de outra. "44

Portanto, cabe ao presente estudo, através da revisão bibliográfica, contextualizar as variáveis em um universo que aponta para tempos e espaços sobrepostos (neste final da primeira década dos anos 2000), calcado na velocidade comunicacional e nas multiplicidades culturais contrapondo-se em um mundo constituído pelo imediatismo e a instantaneidade; mundo globalizado, no qual as principais forças de organizações sociais desenvolvidas pelo projeto de modernidade perdem visivelmente parte de seu poder, seja por corrupção e escândalos, por falta de articulação política, seja pelo desmantelamento de categorias trabalhadoras detentoras de monopólios, ou pelo crescimento do consumo em detrimento da cidadania ${ }^{45}$. Um mundo em que o moderno agoniza e o pós-moderno acena sem apresentar-se. Soma-se a isso uma análise acadêmica, por vezes ensaística, que se fará necessária para a construção textual desta dissertação.

Ressalte-se, pois, que o presente trabalho se define na extensão do termo dissertação sobre um tema, com bases conceituais, técnicas e empíricas, não avançando para uma tese com correlação de dados e argumentos que materializam uma reflexão não só inédita, mas demonstrativa mais do que dissertativa.

Para a execução deste trabalho de modo sólido, estruturado em âmbito conceitual e teórico, serviu-se de dados empíricos primários (com pesquisa de campo para a aferição das tendências de uso do mobile em comunidades

\footnotetext{
${ }^{44}$ MERTON, Robert. Sociologia: teoria e estrutura. São Paulo: Mestre Jou [s. d.] p. 546

${ }^{45}$ Sobre a questão de consumo e cidadania ver CANCLINI, Néstor Garcia. Consumidores e cidadãos. Rio de Janeiro: UFRJ, 1999.
} 
específicas) e secundários (a partir da bibliografia e de informações disponíveis na web) que apresentassem caminhos de análise da problemática proposta. Para contextualizá-lo à sociedade a partir da qual se observa esse fenômeno, utilizou-se, na coleta de dados, o método de abordagem hipotético-dedutivo ${ }^{46}$, como método de procedimento o estudo de caso ${ }^{47}$, pois acredita-se também que enquanto um lado se desmantela (de cidadania), outras formas de articulação se manifestam em oposição ao global, e a partir dele, como é o caso do reforço das relações locais ${ }^{48}$.

Os dados empíricos são aqui apontados como referência complementar de apoio, não se constituindo como razão de ser da argumentação proposta, na sua característica de dissertação.

Dentro ainda deste panorama, fica praticamente impossível um controle sobre fronteiras simbólicas, ou sobre os possíveis sujeitos que se formam em seus interiores, cabendo a eles o próprio reconhecimento de suas condições, e à ciência a análise e resultados desses movimentos.

Esta busca de referenciais empíricos sobre a tendência dos usos do celular e das práticas sociais foi efetuada em três espaços distintos: dois (morros e bairros de praia) vinculados a um elemento principal: a proximidade à praia que, pode-se afirmar, determina o sentimento de status dos indivíduos e a percepção do lugar social que ele ocupa; o terceiro espaço é um ambiente de passagem, no qual os vínculos de freqüência são o trabalho e o consumo (centro da cidade).

\footnotetext{
46 “Que se inicia pela percepção de uma lacuna nos conhecimentos acerca da qual formula hipóteses e, pelo processo de inferência dedutiva, testa a predição da ocorrência de fenômenos abrangidos pela hipótese". (MARCONI, Marina de Andrade, LAKATOS, Eva Maria. Metodologia do trabalho cientifico. São Paulo: Atlas, 2001, p. 106)

${ }^{47}$ Análise do resultado de observação direta extensiva por formulário, realizada na primeira semana de junho de 2008, sobre as tendências dos usos de aparelhos celular em espaços urbanos distintos (morro, praia e centro) na cidade de Santos; espaços estes representantes de condições sócio-econômicas antagônicas sob uma mesma perspectiva cultural (o vínculo com a praia e o mar).

${ }^{48}$ É importante perceber como "os sujeitos políticos aumentam o seu espaço de jogo na medida em que conseguem aumentar sua riqueza cooperativa"; cabe lembrar a redução do papel do Estado, em especial após a Segunda Guerra, momento a partir do qual a soberania "é repartida por diversas instituições local, regional, nacional, estatal e internacional - e limitada por essa pluralidade" (INNERARITY, Daniel. A transformação da política. Lisboa: Teorema, 2002, p. 177, 178).
} 


\section{O TELEFONE CELULAR NA DESIGUALDADE}

Para a abordagem da temática proposta no título é necessário esclarecer alguns pontos que permitam o posicionamento epistemológico deste trabalho. $\mathrm{Na}$ introdução explicitaram-se o desenvolvimento e a expansão do celular através de um percurso histórico e sócio-econômico. Também foram apresentadas algumas ações representativas pelo uso da tecnologia portátil móvel.

No entanto, como mediador de comunicação o telefone celular é um instrumento que intermedeia relações - sociais, culturais, simbólicas, econômicas - e desse modo representa seu usuário pelos hábitos de uso, por suas escolhas, seus gostos e demais significados efetivados; pelo que nele está contido e através dele é manifesto. Com efeito, o celular permite realizar práticas sociais que partem dos indivíduos, das comunidades, ou de estruturas sociais e suas interpretações.

A escolha do termo "estrutura social", apesar de seus sentidos, aqui manifesta a desigualdade que ela engendra e define a episteme através da qual se opera este estudo. Dado o fato de que o objeto observado é a desigualdade social reproduzida pelo celular, parte-se da idéia de que na sociedade contemporânea "as expressões culturais são retiradas da história e da geografia e tornam-se predominantemente mediadas pelas redes de comunicação eletrônicas que interagem com o público e por meio dele em uma diversidade de códigos e valores, por fim incluídos em um hipertexto audiovisual digitalizado", explica Castells ${ }^{49}$. Atêm-se, portanto, às características de uma sociedade enredada por tecnologias digitais das mais variadas, que idealiza seu mundo e manifesta estas idealizações através desses instrumentos tecnológicos, direta ou indiretamente, e que mantém ou reestrutura representações de desigualdade.

Não se enxerga somente o modelo de sociedade sólido do marxismo, ou o estruturado por Weber ${ }^{50}$, mas não se crê plenamente na liqüidez proposta por

\footnotetext{
${ }^{49}$ CASTELLS, Manuel. A sociedade em rede. São Paulo: Paz e Terra, 1999, p. 572.

${ }^{50}$ WEBER, M. Op. cit.
} 
Bauman $^{51}$, ou no apelo às "tribos" nômades de Maffesoli ${ }^{52}$. Ainda que todas as propostas desses autores sejam constituintes da condição humana -- bem como através dela constituam-se - encontra-se a precisão necessária para estudar a desigualdade em autores que transitam entre o moderno e o pósmoderno; que percebem mudanças nas condições, mas preferem não nomeálas definitivamente por estarem ainda em curso.

Necessariamente deve-se conceituar desigualdade a partir do espaçotempo histórico em que se percebe sua relevância. Posteriormente podem-se avaliar os espaços através dos quais ela opera (simbólicos, físicos, de classe, de prestígio), e dessa forma partir para a interpretação de sua relevância na esfera da produção e reprodução de bens simbólicos com os usos de tecnologias celulares.

\subsection{Desigualdade: uma questão de classe?}

Em um primeiro momento atem-se à desigualdade operando entre dois sistemas dentro de uma abordagem sociológica: "como fato social, mas também como um esquema interpretativo da realidade social, indagando sobre sua função nessa realidade ${ }^{53}$. Desse modo o discurso sobre desigualdade transita na realidade que o produz, sendo portanto uma representação cultural de fatos sociais. Klaus Eder defende a tese de que a desigualdade surge das "diferenças sociais entre atores sociais", levando-os à separação em classes. Essa classificação leva às diferenças de classe - a partir da raça, da condição econômica, da religião, do status, entre outras -- a serem percebidas como desigualdade (dentro de categorias verticalizadas).

As sociedades simples, as tradicionais e as modernas classificam pessoas verticalmente: as primeiras por sexo, idade e linhagem; as segundas por estamentos e castas; e, na modernidade, efetiva-se a divisão por

${ }^{51} \mathrm{Ou}$ em qualquer outro modo de totalidade condicional que possa inibir as raízes da modernidade de serem manifestas a partir das estruturas ou sistemas, ainda que aparentemente inúmeras rupturas se apresentem e serão debatidas ao longo do texto. Sobre modernidade líquida, e o dinamismo atribuído a ela (que não necessariamente representam a leveza atribuída por Bauman), ver BAUMAN, Zygmund. Modernidade líquida. Rio de Janeiro: Jorge Zahar Editores, 2001.

${ }^{52}$ Fala-se em tribos, em lugar de sociedades, como forma de pertencer a determinados grupos, mas, numa "modernidade líquida", em que os processos de relacionamentos são superficiais e efêmeros, sem constituir laços afetivos sólidos, quando muito por interesses objetivos em comum. Ver, MAFFESOLI, Michel. Tempo das tribos: o declínio do individualismo nas sociedades de massa. Rio de Janeiro: Forense Universitária, 2000.

${ }^{53}$ EDER, Klaus. A nova politica de classe. Bauru, SP: EDUSC, 2002, p. 140. 
conquistas individuais (pelo acúmulo de capital através do trabalho, ou da exploração dele, por exemplo). No entanto somente os modernos denominamse como sociedade de classes, permitindo conceituar desigualdade como algo ligado à "emergência do discurso" sobre igualdade, aparente no século 18.

A desigualdade torna-se, portanto, "um esquema interpretativo produzido por uma representação cognitiva da sociedade moderna que é depois projetada sobre outras sociedades ${ }^{54}$."

O discurso sobre desigualdade surge, destarte, como um mecanismo de reclassificação das diferenças existentes nas sociedades, que acontece através dos conceitos de lutas classificatórias: a priori a luta pela renda ${ }^{55}$ e luta pela qualificação formal ${ }^{56}$, posteriormente a luta pelo bom gosto ${ }^{57}$ e pela excelência moral ${ }^{58}$. Dessa forma, ainda sob a égide da modernidade dividemse as classes de acordo com os recursos materiais e simbólicos de que elas dispõem, em perdedores e vencedores, "merecedores" das condições que the são dadas graças ao acúmulo de bens ou de cultura, que Ihes diferencia do outro.

Na seqüência, agrega-se à categorização de classe também a aquisição de cultura, esta quanto mais sofisticada (em relação à arte, estética, política moral ou tecnológica) mais gradua seu portador. Aparentemente, critica Eder, "ela nos permite distinguir entre aqueles que têm opiniões, aqueles que sabem que opiniões ter (e só poucos sabem) e ter pena daqueles que não têm. ${ }^{59 ",}$ Desse modo, ocupação e opinião (somadas à renda, à qualificação, ao gosto e a moral) tornam-se também duas variáveis importantes para caracterizar a existência social na escala vertical.

No entanto a estrutura de classes (vinculada aos valores das sociedades civilizadas) vai tendo seu sentido cada vez mais esvaziado diante de um crescente individualismo ${ }^{60}$, ela passa a ser visível especialmente por análises

\footnotetext{
${ }^{54}$ EDER, K. Idem, p. 145.

${ }_{56}^{55}$ BELLMANN et al. 1984, apud EDER, K. Ibidem, p. 146.

${ }^{56}$ BLOSSFELD, 1984, apud EDER, K. Ibid. p. 147

${ }^{57}$ BOURDIEU, Pierre. A distinção: crítica social do julgamento. São Paulo: Edusp; Porto Alegre, RS: Zouk, 2007.

${ }^{58}$ GUSFIELD, 1966, 1981b. Apud EDER, K. Op.cit. p. 147.

${ }^{59}$ EDER, K. Id. p. 149.

${ }^{60}$ A valoração do individualismo superando a sociedade é contestável se se levar em consideração que somente "a partir de um certo momento da história ocidental, os homens passaram a se ver como indivíduos", segundo Dumont, mas isso não significa que "os homens (...) deixaram de ser seres sociais no dia em que se conceberam de uma maneira contrária". (DUMONT, apud CORRÊA, Diogo. Somos
} 
estatísticas que a relativiza frente a um padrão definido pelo fato social que é. Em outras palavras, fora da estrutura de classes não há critérios de desigualdade. Empiricamente, isso aparece nas pesquisas de opinião e suas divisões por faixas de rendimento, idade, lugar de origem e nível educacional, que passam a representar uma determinada classe em um tempo/espaço específico.

Com as mudanças nas estruturas sociais (não o seu fim) que impulsionaram as relações para algo distinto da solidariedade, da consciência de classe e da homogeneidade (e assim de uma pretensa igualdade), alguns chegam mesmo a decretar o fim das classes sociais:

Uma classe real seria definida por sua homogeneidade de condições objetivas e subjetivas de existência social e aprovada empiricamente por sua co-variação estatística. Usualmente, quando os testes mostram que tal homogeneidade não ocorre, a conclusão é que as classes não existem mais na sociedade moderna. (BOLDE; HRADIL, 1984; HRADIL, $1987^{61}$ )

O que acontece, no entanto, é um deslocamento das classes sociais dos modelos propostos pelo tradicional e pelo moderno, para os formatos dinâmicos das sociedades do final do século 20. Adicionam-se a isso toda a gama de instrumentos de comunicação, que enredados, satelitizados, digitalizados, e acelerados, passam a efetuar trocas simbólicas ignorando fronteiras e temporalidades.

Os grupos com correlações significativas tornam-se então "ambientes", substitutos dos modelos de classe tradicionais. Nessa proposição, no entanto, a própria classe subjetiva é construção de uma posição objetiva de classe.

No início do século 21 um modo eficiente para identificar classe social é descrevê-la a partir de sua experimentação, percepção e interpretação de mundo, dessa forma vinculando-a a uma cultura dominante, mas a partir da qual surgem subculturas (os conceitos de cultura e práticas culturais são abordados no próximo capítulo).

Com efeito, determinados elementos simbolizam uma cultura específica, contudo as possibilidades de apropriação e reapropriação simbólica dependem

desiguais? a propósito de Jessé Souza e Roberto DaMatta. In: SOUZA, Jessé (org.). A invisibilidade da desigualdade brasileira. Belo Horizonte: UFMG, 2006, p. 362, 363.

${ }^{61}$ Idem, p. 157. 
dos usos, ações, desejos, vontade, interesse e competência dos que dela participam, e do lugar em que o individuo se coloca (ou é colocado) na escala do grupo ao qual pertence (ou quer pertencer). A essa posição denomina-se prestígio:

É o prestígio derivado do fato de pertencer a uma classe que conta. O prestígio é atribuído, no entanto, apenas quando um grupo é fechado, sua quantidade é limitada (maximizando seu valor de mercado) e seu etos é controlado (para integrar o grupo). Assim, é o prestígio utilizado usualmente para representar a desigualdade social que se torna o indicador de classe mais significativo, não apenas em relação ao consumo cultural, mas também em relação a algumas ocupações de importância central para a sociedade moderna. (WEGENER, 1985, apud EDER, 2002, p. 164)

Percebe-se, portanto, que "para captar diferenças subculturais, o cientista social precisa investigar os esquemas interpretativos que determinam a prática cultural numa dada sociedade ${ }^{62 "}$. Ou melhor, ao investigador cabe compreender o lugar a partir do qual se processam os significados que permitem a identificação de pessoas ou grupos desiguais (muitas vezes não importando se denominadas classes, estratos, ambientes) desde que se encontrem padrões através dos quais se possam referenciá-los (daí o reescalonamento do conceito de tribo por autores considerados pósmodernos).

Essa idéia aplicada na observação dos usos do celular permite, por exemplo, observar práticas distintas em aparelhos semelhantes, tendo como referencial o espaço cultural de produção de sentido a partir do qual o usuário opera (o lugar de origem e de produção simbólica no uso do mobile). Este espaço pode estar no global, no nacional, no regional, ou no local (tanto quanto na relação familiar, interpessoal ou individual), mas a seleção específica de ações, linguagens, tecnologias e possibilidades apontam para a esfera que é então articulada para a concretização do uso ${ }^{63}$, as comunidades.

A prioridade deste estudo não é o que os celulares têm, mas sim o que se faz com eles, desde que sua observação apreenda o espaço cultural (simbólico) acionado pelo usuário no momento de uso do aparelho, para

\footnotetext{
${ }^{62}$ EDER, K. Op. cit. p. 158, 159.

${ }^{63}$ É extremamente necessário frisar que o aparelho celular, como meio de comunicação, carrega consigo as possibilidades de produção, emissão, meio, mensagem, recepção e interpretação.
} 
posteriormente verificar se os objetivos de uso são reprodutores de desigualdades social, econômica, ou cultural.

\subsection{Desigualdade nas manifestações contemporâneas}

O século 21 se inicia com deslocamentos (ou convergências) relevantes: de cidadão a consumidor, das classes sociais à tribo, das sociedades às minorias, do Estado às ONGs; globalização econômica, mundialização da cultura, transnacionalização de relações, eliminação das fronteiras. Ao mundo físico soma-se o virtual: o real dá lugar também à simulação, o complexo ao fractal, a pele à tela, a ordem à velocidade.

É nesse brevíssimo panorama do mundo atual, em que os grandes discursos (ou meta-relatos - que tentaram incluir em si todos os elementos constituintes da sociedade) dão lugar ao imediatismo, às efemeridades, talvez para obliterar a ordem proposta pela razão que deixou no rastro suas guerras; um período em que as vidas se alongam sem que se estendam os sentidos. Um lugar no qual, para muitos, as tecnologias superam a humanidade.

Frente a essa complexa condição intensificam-se as diferenças através da apresentação das semelhanças, somadas às trocas -- comunicacionais, simbólicas e culturais -- intensas concretizadas pelo aparato tecnológico que, não somente se faz presente, como reestrutura a ordem de relações sociais, até então limitadas em um único tempo-espaço.

A distribuição de produtos industrializados, tecnológicos e simbólicos entre as mais variadas partes do planeta proporcionam a renovação incessante de posições sociais e sua hibridação, como também o reforço de perspectivas tradicionais e modernas a partir da significação. São formas contemporâneas da base, em que o produto industrial dá lugar aos serviços, tendo como modo de atualização a cultura processada pelos media (de massa e digitais).

Torna-se necessário perceber que dadas as circunstâncias em que a sociedade se inscreve "não se podem opor 'gostos de liberdade' das classes hegemônicas a 'gostos de necessidade' das populares”, explica Canclini ${ }^{64}$. Para ele, "ainda que os setores subalternos não disponham de tempo nem dos recursos econômicos da burguesia para se entregarem a uma 'estilização' de

${ }^{64}$ CANCLINI, Néstor, Garcia. Diferentes, desiguais e desconectados. Rio de Janeiro: UFRJ, 2005. 
sua vida, não vivem uma vida sem estilo". Com efeito, o que se vê é a reestruturação física e/ou simbólica do que se apresenta em diferentes esferas, e uma aplicação dessas interpretações de acordo com as possibilidades de cada um.

A teoria da "legitimidade cultural", que reduz as diferenças a faltas, as alteridades a defeitos, não consegue ver a estilização que se imprime a diferentes partes da casa, tudo aquilo que os adolescentes populares cultivam nos enfeites do seu corpo, na roupa e na cosmética, nos seus automóveis e motocicletas, no ambiente de seus quartos ou lugares de diversão. (CANCLINI, 2005, p. 88)

Não se apagam, contudo, os traços do relativismo cultural "que imagina os subalternos apenas como diferentes, num estado de 'inocência simbólica'”; nem a idéia do "etnocentrismo das classes dominantes ou 'dos grupos cultos associados ou aspirantes ao poder', que crendo monopolizar a definição cultural do humano, consideram o diferente como 'barbárie' ou 'incultura ${ }^{65}$ '”. Afinal, tensão entre ambas as forças permeiam os modos de ver os ambientes e assim classificá-los.

Mas o ideal, num modelo de sociedade enredada tecnológica, econômica e culturalmente, é apropriar-se dessas tensões e a elas somar atualizações. Isso porque "a sociedade, antes concebida em termos de estratos e níveis, ou distinguindo-se segundo identidades étnicas ou nacionais, agora é pensada como metáfora de rede", afirma Canclini. Agora os incluídos estão "conectados", cabendo aos outros a exclusão, pois "vêem rompidos seus vínculos, ao ficar sem trabalho, sem casa, sem conexão. ${ }^{66 ", ~}$

Vive-se em um momento no qual os instrumentos de integração (celular, computador, PCs), somados aos de regulação da vida pessoal (trabalho, identidade, crédito), tornam-se o limiar entre os que pertencem e os que não. Nesse cenário os espaços se ampliam virtualmente, estendem os locais, as cidades, paradoxalmente minimiza-se o mundo. Têm-se desse modo um modelo atualizado do urbano.

Geólogos e urbanistas têm definições peculiares para a cidade, o urbano e espaço público. A cidade pode ser vista primordialmente como um lugar de

\footnotetext{
${ }^{65}$ GRIGNON, Claude, PASSERON, Jean-Claude. Lo culto y lo popular: miserabilismo y populismo en sociologia y en literature. Buenos Aires: Nueva Visión, 1991. Apud CANCLINI, ibid. p. 89.

${ }^{66}$ CANCLINI, N. G. Op. cit. p. 92.
} 
mercado, onde se dá um intercâmbio regular de mercadorias ${ }^{67}$, uma localidade central (do ponto de vista geoeconômico, segundo $C$ hristaller ${ }^{68}$ ), medida pela grandeza de bens e serviços que ela oferta. Mais relevante, entretanto, é a cidade descrita como local onde as pessoas se organizam, interagem com base em interesses e valores diversos, formando "grupos de afinidade e de interesse menos ou mais bem definidos territorialmente com base na identificação entre certos recursos cobiçados e o espaço, ou na base de identidades territoriais que os indivíduos buscam manter e preservar ${ }^{69}$."

Para Lopes de Souza a lógica urbana é a do solo como suporte para a produção industrial, habitação e circulação; atividades que independem de seus atributos de fertilidade, ou para a agricultura e pecuária (como é para a lógica rural). Espaço público aqui é "o lugar, praça, rua, shopping, praia, qualquer tipo de espaço onde não haja obstáculos à possibilidade de acesso e participação de qualquer tipo de pessoa ${ }^{70 "}$, dentro de regras de convívio e debate. Um espaço de convivência e conflitos entre diferenças; portanto também de expressão da compatibilidade a um só tempo formado na matriz social-econômica, e por derivação, um espaço político-econômico.

Há algum tempo é possível observar a miniaturização das tecnologias agregada à hibridação com aparelhos comunicacionais que possibilitam inúmeras ações antes restritas a uma base (como a televisão com vídeo, o telefone com secretária eletrônica ou o computador, seus programas e jogos). O aparelho de telefonia móvel celular invade as casas, os espaços, os cotidianos, os corpos, acompanhando movimentos, desejos e expressões na esfera privada e nos espaços públicos.

O resultado é a reestruturação de práticas culturais e sociais mediadas tecnologicamente por aparelhos comunicacionais digitais e com isso traz-se ao debate uma nova relação homem-máquina ${ }^{71}$. Inserir o aparelho celular na categoria protética (um objeto hoje tornado indispensável e associado a uma

\footnotetext{
${ }^{67}$ WEBER, Max. Apud LOPES DE SOUZA, Marcelo. ABC do desenvolvimento urbano: Rio de Janeiro: Bertrand Brasil, 2007, p. 25.

${ }^{68}$ CHRISTALLER, Walter, apud LOPES DE SOUZA, M. Idem, p. 25.

${ }^{69}$ LOPES DE SOUZA, M. Ibidem, p. 28.

${ }^{70}$ COSTA GOMES. Apud SUN, Alex. Projeto da praça: convívio e exclusão no espaço público. São Paulo: Senac, 2008, p. 20, 21.

${ }^{71}$ Vide SOUSA, Mauro Wilton de. Sujeito o lado oculto do receptor. São Paulo: EDUSP, 1995.
} 
gama de ações inimagináveis há menos de dez anos) é acompanhar a reconfiguração do tempo e do espaço que submetidos ao mobile ${ }^{72}$ passam a não mais existir num único momento, mas em vários, estendidos em sua interface surgem cibervias com intenso fluxo de trocas simbólicas.

Desencadeia-se o tempo real e remodela-se a percepção humana (a ilusão presencial - o estar junto, o ter/estar presente através do deslumbre tecnológico). O corpo passa a ser um suporte das vias, mesmo que continue a viver no estrato material da existência. Pelo celular a cibercultura se manifesta junto ao corpo, que passa a vivenciá-la enredado durante seu deslocamento, a se comunicar via satélite com qualquer lugar do planeta nomadicamente.

Remeter-se-á à mídia locativa ${ }^{73}$, em que espaços com mecanismos digitais adaptados, permitem o "monitoramento, a vigilância, mapeamento, geoprocessamento (GIS), localização, anotações ou jogos”, Estes espaços estendem as ruas para além de seu ambiente físico, proporciona um mergulho no ciberespaço, bem como traz este espaço para o mundo real, esferas que se completam e coexistem, e se tornam infinitos graças à protetização do aparelho ao corpo. Representam-se os acontecimentos físicos e os que se processam pelo aparelhamento.

A convergência desses universos dá origem à ciberurbe ${ }^{74}$, em que tudo está disponibilizado para o todo, anarquicamente livre. No entanto, as diferenças que operam na esfera social (de raça, etnia, tradições, cultura, posição social, prestígio ou status) não somente são deslocadas também para o universo cibercultural, como permanecem regendo processos de posicionamento de determinados grupos em patamares diferentes de outros. É, portanto, nas duas esferas que formam um só ambiente, o cibercultural, que a desigualdade pode ser simbolizada. Através das impossibilidades que permanecem, insistentemente, a comunicação reproduz nos espaços

\footnotetext{
72 Aqui deve-se esclarecer, pois, que não somente o celular é responsável por essa transformação, entretanto pela sua acessibilidade torna-se um objeto importante para o contexto de deslocamento do espaço.

${ }^{73}$ Mídia locativa são dispositivos informacionais digitais cujo conteúdo da informação está diretamente ligado a uma localidade para serem acessados por GPS, celulares, ou etiquetas, por exemplo.

74 "A ciberurbe, a alma virtual das cibercidades, configura-se, cada vez mais, por práticas sociais que emergem dessa mobilidade informacional digital (trocas de SMS, comutadores e trabalhadores nômades, ocupações de espaços urbanos conectados, jogos por dispositivos móveis em mobilidade no espaço urbano, anotações eletrônicas digitais, mobile blogs, trocas de textos, vídeos e fotos por celulares)". (LEMOS, A. Op. cit. 2007, p. 131,132)
} 
relacionais a mesma matriz de desigualdade apontada desde o econômico, político e social.

\subsection{Desigualdade comunicacional}

Imbricados à percepção da desigualdade, os meios de comunicação massivos têm um papel importante na produção, distribuição e consumo de bens simbólicos. Dessa maneira, estimulam a crítica e o acesso à informação, bem como a interligação (globalização) dos continentes, acelerando o processo de conhecimento e de reconhecimento de diferenças. Isso se processa, no mundo ocidental, desde a bíblia de Gutemberg, não a primeira obra impressa, mas simbolicamente a primeira em relevância para a sociedade européia, por volta de 1450.

Graças a esse instrumento, Lutero (1483-1546), através da tradução da Bíblia do latim (língua da elite intelectual e dos clérigos) para o alemão, possibilitou acesso do povo à interpretação do sagrado. E, se Lutero foi pioneiro no compartilhamento de conteúdos, Calvino talvez tenha sido o primeiro na crítica aos excessos, com a onda de impressão que se seguiu: em 1550 havia "tantos livros que não temos nem tempo de ler os títulos. ${ }^{75}$ "

Os media impressos (livros, jornais e revistas) mantém-se em destaque ainda durante o século 18, e foram fundamentais para a propagação das idéias de liberdade, igualdade e solidariedade que culminaram na Revolução Francesa, bem como fomentaram uma nova categoria de ilustrados e fizeram surgir os românticos; os primeiros em defesa da razão e do conhecimento, os segundos amparando a manifestação dos sentimentos.

Mas é no século 19 que se dão as grandes revoluções características da modernidade em âmbito técnico e tecnológico. Fotografia, rádio, cinema, telégrafo e telefone, acompanham e retratam a industrialização, a reconfiguração dos modelos de relações sociais, comerciais e de trabalho. Multiplicam discursos para uma população que agora se aglomera nos centros urbanos, formando a primeira geração de $\operatorname{slum}^{76}$, "em meados do século 19 ,

${ }^{75}$ BRIGGS, Asa; Burke, Peter. Uma história social da mídia. Rio de Janeiro: Jorge Zahar Editores, 2004, p. 29

${ }^{76}$ O termo inglês Slum, a priori, "sinônimo de racket ,'estelionato' ou 'comércio criminoso"” (...) posteriormente passa a denominar "cômodos onde se faziam transações vis", já incorporando o significado de favela. (DAVIS, Mike. Planeta favela. São Paulo: Boitempo, 2006, p. 32) 
identificavam slums na França, na América e na India". Na Inglaterra, segundo Briggs e Burke ${ }^{77}$, "os especialistas e diletantes debatiam onde a degradação era mais horrenda: Whitechapel ou La Chapelle, Gorbals ou Liberties, Pig Alley ou Mulberry Bendy".

Essa situação, que não somente mescla diferenças, mas passa a forçar a desigualdade, é registrada pelos meios de comunicação em texto e imagem. Os movimentos revolucionários que percebem essa condição degradante da humanidade, como o anarquismo, o comunismo e o socialismo, ganham corpo graças aos "panfletos", distribuídos às massas, que surgem então. Bakhunin, Proudhon, Marx, Engels, demonstram e criticam os mecanismos de desigualdade impostos pelo capitalismo e passam a polarizar, através do discurso da desigualdade -- reproduzido pelos recém surgidos mass media -dimensões opostas que vão nortear a tensão entre nações durante todo o século 20 .

Com o crescimento da indústria fonográfica, radiofônica e cinematográfica, as três primeiras décadas do século passado retrataram mudanças radicais nos modos de concepção do mundo. Os centros urbanos hibridam culturas (ainda que não de maneira perceptível naquele momento) ao mesmo tempo em que reforçam diferenças e expõem as desigualdades. Imagens registram a insatisfação das multidões durante a Revolução Russa (1917), em cinema e fotografia; a primeira Grande Guerra torna-se um evento mediatizado, com correspondentes para os grandes jornais europeus e norteamericanos. A indústria cinematográfica traz uma idealização das dificuldades sociais do período com Chaplin (O garoto), ou Eisenstein (Encouraçado de Pontenkin).

O processo de mediatização das relações sociais, bem como uma suposta redução da cultura ao processo de reprodução industrial, torna-se o foco dos estudos (recém-nascidos) em comunicação. Primeiramente visando a manipulação de conteúdos para tornar mais eficaz o produto comunicacional a ser distribuído, com a Escola de Chicago, nos EUA; os funcionalistas, após os postulados iniciais de Lasswell (e a sua teoria hipodérmica), se impõem graças aos recursos de produção que financiam suas pesquisas, com fórmulas ainda

\footnotetext{
${ }^{77}$ BRIGGS, A, BURKE, P. Op. cit. 2004.
} 
hoje adotadas, como a mensuração da audiência quantitativamente, com vistas à manutenção da estrutura econômica.

No entanto, é com os europeus, mais especificamente com os estudiosos da Escola de Frankfurt, na Alemanha, que as tensões entre os mass media e a cultura se efetivam, através da teoria crítica. Disciplinas setorizadas e a função ideológica das ciências, para os frankfurtianos, produzem "dados de facto", e que na teoria crítica são produto de "uma situação histórico-social específica" ${ }^{78 " . ~ H o r k h e i m e r ~ e x p l i c a ~ q u e ~ " o s ~ f a t o s ~ q u e ~ o s ~}$ sentidos nos transmitem são pré-fabricados socialmente de dois modos através do caráter histórico do objeto percebido e através do caráter histórico do órgão perceptivo". Para o autor, "nem um, nem outro são meramente naturais; são, pelo contrário, formados por meio da atividade humana".

Denunciando a separação e a oposição do indivíduo em relação à sociedade como resultante histórica da divisão de classes, a teoria crítica confirma a sua tendência para a crítica dialética da economia política (...). O ponto de partida da teoria crítica á a análise do sistema da economia de mercado: "desemprego, crises econômicas, militarismo, terrorismo, a condição global das massas - como é sentida por elas não se baseia nas possibilidades técnicas reduzidas , como era possível no passado, mas em relações produtivas já não adequadas à situação actual". (HORKHEIMER, 1937, apud RUSCONI, 1968 p. $267^{79}$ )

Em outras palavras, com a convivência dos diferentes, determinados grupos verticalizam o prestígio, a estratificação, o capital e os bens simbólicos em classes sociais que opõem o indivíduo à sociedade. A desigualdade é moldada pela indústria cultural em seu processo de estandardização, no qual "a explosão dos conflitos é pré-estabelecida e todos os conflitos são meras imitações. A sociedade é sempre vencedora e o indivíduo não passa de um fantoche manipulado pelas normas sociais", discursa Adorno ${ }^{80}$.

Cabe ressaltar, como mostra Marcondes Filho, que "a Escola de Frankfurt começou com um hegelianismo de esquerda e terminou com um discurso nietzscheano ou heideggeriano da implosão das totalidades e da busca localizada das diferenças". Para o autor, Adorno no fim de sua vida, por

\footnotetext{
${ }^{78}$ WOLF, Mauro. Teorias da comunicação. Lisboa: Presença Editorial, 1999.

${ }^{79}$ In: WOLF, M. Idem, p. 83.

${ }^{80}$ ADORNO, Theodor. Televisione e modelli di cultura di massa, 1954. In: LIVOLSI, M. Comunicazione e cultura di massa. Hoepli: Milão, 1969, p. 379, 393.1954, p. 384.
} 
exemplo, "sai à caça do estranho, do que destoa, do que não se adapta, do que é inusitado. É o belo estranho, que ele descobre em Eschendorff: o que a consciência vivencia como estranho é o que deve ser amado como diferente, diz ele ${ }^{81 ",}$ demonstrando assim percepção às alterações constituintes das modificações sociais.

Após a Segunda Grande Guerra, a televisão passa a fazer parte dos lares (primeiramente norte-americanos e posteriormente, em 30 anos, do mundo todo), tomando o centro da atenção dos estudiosos em comunicação, sociologia, linguagem e antropologia, graças ao vasto repertório possível de ser extraído de seu conteúdo. Surgem discursos laudatórios que esperam a união de todas as sociedades em torno do aparato televisivo formando uma grande "aldeia global ${ }^{82 " .}$

Mas é um representante dos estudos culturais ${ }^{83}$ que vai apresentar um dos textos mais relevantes para a compreensão do papel da televisão, ou melhor, da recepção a produtos mediáticos televisivos. Em "Codificar e decodificar $^{84 ",}$ Stuart Hall problematiza aspectos da relação mediada pela TV sob a ótica de todas as instâncias do processo de codificação e de decodificação das mensagens (processo que perpassa a infra-estrutura técnica, as relações de produção, os referenciais de conhecimento e as estruturas de sentidos, resultando no produto televisivo como discurso significativo), deslocando o debate da significação para a esfera da recepção e dos elementos processados (denotativos e conotativos ${ }^{85}$ ) nessa esfera para efetivarem-se os significados dados às mensagens.

É notável, pois, o estreitamento dos vínculos entre os estudos de comunicação e o desenvolvimento das sociedades e das tecnologias postas

81 MARCONDES FILHO, Ciro. Martín-Barbero, Canclini, Orozco: os impasses de uma teoria da comunicação latino americana. Revista Famecos. Porto Alegre, n. 35, abril de 2008, p. 71.

${ }^{82}$ MCLUHAN, Marshall. In: COSTA LIMA, Luiz. Teoria da cultura de massa. São Paulo: Paz e Terra, 2000 .

${ }^{83}$ Falar da tradição dos estudos culturais em espaço tão curto é tarefa impossível. Para tanto, indica-se o texto de Stuart Hall, Estudos culturais: dois paradigmas (in Da diáspora. Belo Horizonte: UFMG, 2003, p. 131.)

${ }^{84}$ HALL, Stuat. Codificar e decodificar. In: Da diáspora. Belo Horizonte: UFMG, 20032003, p. 391.

${ }^{85}$ Hall opera o sentido literal de um signo (denotação) juntamente com os significados que se geram em associação com o signo (conotação). "Os termos denotação e conotação são meramente ferramentas analíticas úteis para se distinguir, em contextos específicos, os diferentes níveis em que as ideologias e os discursos se cruzam, e não a presença ou ausência de ideologia na linguagem”. (HALL, S. Idem, p. 395) 
em seus cotidianos como ferramentas simbólicas. Também é aparente o acúmulo de disciplinas que se interessam pelo fenômeno comunicacional mediado (de massa ou não), vista a importância deste para o transporte de culturas, informação, significados, conhecimento, ideologias ${ }^{86}$, e pelo importante papel na dinamização da economia e da manutenção das instituições religiosas e de Estado.

Certamente por isso Wolton afirma que "comunicar é ser livre, mas é, sobretudo, reconhecer o outro como seu igual. $E$ assim encontramos toda a batalha pela democracia, ou seja, o direito de oposição, o pluralismo - a liberdade, portanto - e também os direitos do homem - a igualdade".

Entretanto essa igualdade não se efetiva ao longo de todo o século 20. Pelo contrário, uma desigualdade surge e se acentua brutalmente, quando se expõe à esfera do econômico. Só para se ter uma idéia, já no início do século 21, "as duzentas pessoas mais ricas do mundo possuíam mais que o montante detido por um bilhão e quatrocentos milhões de pessoas, e apenas as duas pessoas mais ricas tinham muito mais que o conjunto dos países menos desenvolvidos do planeta ${ }^{87 "}$. Existem mais pessoas ricas do que as nações mais desenvolvidas no século 21 .

Enfim, que desigualdade é essa que se apresenta nos dias atuais? Para Díaz a "desigualdade econômica é aquela caracterizada pela diferença de rendas e capacidade de consumo entre indivíduos e nações”. Já a desigualdade política é "entendida como a diferença com que se exercem os direitos políticos e têm-se acesso ao poder político". E a desigualdade sóciocultural é a "diferença entre grupos populacionais por etnia, gênero, ideologia, capital cultural, e status social $^{88 "}$. Todas são interligadas e tornam o fenômeno da reprodução da desigualdade extremamente complexo.

A desigualdade, no universo comunicacional, torna-se a significação dada às diferenças das esferas de relações sociais (sócio-econômicas, culturais, políticas e comunicacionais), que impossibilitam os atores sociais de representarem papéis semelhantes. Acredita-se que, apesar da disponibilidade

\footnotetext{
${ }_{87}^{86}$ No sentido de idéias compartilhadas por um grupo de pessoas.

${ }^{87}$ DÍAZ, Laura Mota. Instituições do Estado e produção e reprodução da desigualdade na América Latina. In. CIDAMORE, Alberto. Produção de pobreza e desigualdade na América Latina. Porto Alegre: Sulina, 2007, p. 125

${ }^{88}$ Idem. p. 129.
} 
de conteúdos dada pelos novos media, os modos de simbolizar se limitam às possibilidades de operar com os conteúdos do mundo vivido. Têm-se, portanto, uma infinita reprodução de condições.

A desigualdade opera em instâncias variadas: na economia, quando é reproduzida pelo acúmulo de bens e gera possibilidade de consumo de bens distintos entre os que têm e os que não têm; na cultura, conceituada como simbolização, que possibilita acesso a bens simbólicos e variedade interpretativa atribuída a esses bens, independentemente da valoração das culturas (mais ou menos elitistas, comunitárias, tribais etc.); Já a desigualdade na política, surge pela diferença de exercício dos direitos políticos e de acesso ao poder, em qualquer esfera. A desigualdade sócio-cultural demonstra diferenças entre grupos populacionais por etnia, gênero, ideologia, capital cultural, e status social.

Essas desigualdades se efetivam em espaços distintos, inclusive no mediático, e o celular, como espaço mediador de comunicação permite essa efetivação. A possibilidade de manutenção dos mecanismos de funcionamento do celular: o crédito para ligações, a transmissão de dados, o compartilhamento de conteúdos, somente acontece se o econômico permite. Isso, contudo, não impede outras ações representativas pelo apetrecho digital, mas essas ações, em um mesmo grupo social, podem ser limitadas pela falta de acesso ao conhecimento de uma determinada linguagem, pela exclusão a alguns lugares e situações, pela impossibilidade de acesso à informação que facilitariam outras interpretações, não somente às relacionadas com seu contexto (o que, repete-se, não invalida as representações efetivadas em qualquer classe).

As desigualdades acontecem, em graus distintos, na intenção e na efetivação da compra, posse e usos dos telefones celulares. A hipótese desta dissertação é a de que se podem demonstrar desigualdades através das práticas sociais concretizadas pelo uso do telefone celular, dado o fato de que as significações se processam em espaços que mesclam duas condições (modernidade e a pós-modernidade): a cidade, o bairro, o indivíduo (como local) e sua história, a condição econômica, suas frustrações, seus recalques, sonhos e principalmente suas relações sociais (que envolvem em primeira instância a comunicação). Com efeito, acredita-se, pois, em uma tensão entre 
os desejos de uso (de igualdade e inclusão tecnológica, por exemplo) e das possibilidades sócio-econômicas, ante à limitação simbólica proporcionada pelo ambiente (no sentido de estrato social) ao qual se pertence, no momento atual. E ainda que essa constatação não desqualifique qualquer uma das partes, contradiz o discurso democrático propagado pelos estados capitalistas liberais.

Em suma, a desigualdade, para este estudo, é uma representação hierarquizada das diferenças, para a manutenção da posição social econômica e cultural de determinado grupo frente a outro. É, portanto, um modo de simbolizar o lugar social ocupado por alguns, como forma de justificar seus sucessos e fracassos, seus desejos e satisfações, seus gostos e limitações. Não é constituída ideologicamente -- posto que permite o trânsito de conteúdos físicos e simbólicos entre categorias distintas -- e menos ainda impõe uma categoria perpetuamente em posição superior a outra. A desigualdade é, pois, um processo hegemônico, em que os sentidos operam para valorar quem se é, em um tempo dado, e acontece em qualquer esfera de significação, demonstrando constante relação entre diferentes.

O telefone celular, pela intensidade em que se manifesta como mediador de relações (físicas ou simbólicas) no mundo contemporâneo, surge como um meio de comunicação a partir do qual se podem apontar necessidades significativas. Para alguns falar é o suficiente, para outros a comunicação processada pelos componentes tecnológicos é mais relevante. O aparelho então passa a significar a participação do seu proprietário diante do mundo. Jogar, compartilhar, reproduzir músicas ou fotos, essas são algumas ações comumente externadas nas práticas com o aparelho, mas que não se encerram nelas próprias.

Elas dizem algo mais: sobre lugares representados, sobre origens, desejos, possibilidades e a inserção do usuário; sobre o lugar que este indivíduo ocupa, mas que nem sempre percebe. O celular, através das ações explícitas e implícitas simbolizadas em sua posse, no seu manuseio e nos seus atributos, significa algo que pode dizer, sem falar, da condição em que os usuários se colocam social, econômica, ou politicamente. 


\section{SIMBÓLICO, PRÁTICAS E DEMOCRACIA NO CELULAR}

O aparelho celular se torna, na contemporaneidade, um meio de comunicação que atua na representação simbólica e de práticas culturais. Cabe, assim, desenvolver um panorama das condições a partir das quais essas significações e práticas operam até desembocar na esfera das relações efetivadas a partir do telefone móvel.

Isso aponta, inicialmente, para a dinâmica constituída pela comunicação massiva durante a modernidade, a partir do século 17. "O que muda", explica Wolton, é o "fato de entrarmos numa sociedade móvel em que as trocas entre indivíduos têm um valor intrínseco, reconhecido". Para o autor, a troca simbólica livre (sem censores), permite à comunicação assumir "seu lugar normativo ao passar de uma sociedade fechada a uma sociedade aberta ${ }^{89 ",}$ resultando nas mudanças estruturais sociais, culturais, políticas, religiosas, tecnológicas e científicas que se processaram ao longo dos séculos 18 e 19.

Já a partir da segunda metade do século 20 , com o esvaziamento dos discursos políticos, as utopias não concluídas, a dissolução da luta de classes, assistem-se rupturas com matrizes sociais e econômicas totalizantes, com isso surgem mudanças radicais nos processos culturais intercambiados, e uma dinamização dos processos comunicacionais (pela intensificação das redes de TV, rádio, telefonia etc.). Com a transnacionalização da economia e dos produtos simbólicos, distribuídos velozmente ao redor do mundo, a cultura passa a cruzar valores entre regiões extremamente distintas, que então podem ressignificar outras manifestações simbólicas hibridando-as à sua maneira.

É, portanto, na esfera das relações sociais que se percebem mudanças nas expressões, nos conteúdos, e nas formas de produção e reprodução cultural, graças à inflação de referenciais globais reproduzidos nos espaços locais, e a partir também do que é produzido e reproduzido localmente ${ }^{90}$. Introduzem-se novos signos no universo de representação por causa da liberdade das trocas simbólicas (concretizada pelo avanço dos mass media e

\footnotetext{
${ }^{89}$ WOLTON, Dominique. É preciso salvar a comunicação. São Paulo: Paulus, 2006, p. 26.

${ }^{90} \mathrm{~A}$ isso denomina-se o glocal (neologismo a partir da fusão dos termos global com o local), citado no capítulo anterior.
} 
renovada com o universo da web). "Novas práticas surgem para rotular velhas práticas ou velhas palavras são ressignificadas para caracterizar a nova força de práticas sempre existentes", diz Maffesoli ${ }^{91}$, "comunicação e informação dão nova potência a um dos mais sólidos arcaísmos: estar em relação", não importando se essas relações são mediadas ou não. O telefone celular surge nesse cenário como um significante renovado, valorado por suas múltiplas funcionalidades, mas principalmente por sua pluralidade comunicacional.

Essa pluralidade permite a formação de inúmeros códigos, deslocados da linguagem verbal codificada pela gramática. Desse modo, diz-se algo de outras maneiras que não somente pela língua (através dos híbridos contidos no telefone celular, por exemplo). E mesmo que a representação deste algo dito dê-se pela codificação do idioma, "o mais complexo e o mais difundido dos sistemas de expressão", segundo Saussure -- e ainda que a lingüística "possa tornar-se o padrão geral de qualquer semiologia, embora a língua seja apenas um sistema particular ${ }^{92 "--, ~ a c r e d i t a-s e ~ q u e ~ a t r a v e ́ s ~ d o ~ m o d e l o ~ e s c o l h i d o ~ p o r ~ u m ~}$ usuário, sua operadora, os usos e as ações realizadas pelo celular, seja possível interpretar relações e práticas, pelo fato de postarem-se como significantes. É, contudo, a linguagem (em suas varáveis) que possibilita a interpretação e o desenvolvimento dos sentidos que tornam esse significante algo codificado.

Um código é um sistema de símbolos. Seu objetivo é possibilitar a codificação entre os homens. Como símbolos são fenômenos que substituem ("significam") outros fenômenos, a comunicação é, portanto, uma substituição: ela substitui a vivência daquilo a que se refere (...) $O$ homem é um animal alienado (verfrendet), e vê-se obrigado a criar símbolos e a ordená-los em códigos, caso queira transpor o abismo que há entre ele e o "mundo". Ele precisa mediar (vermitteln), precisa dar um sentido ao mundo. (FLUSSER, 2007, p. 13093)

Perceba que não se vincula necessariamente linguagem à língua (idioma), mas a um conjunto de códigos que possam significar algo para alguém em um determinado tempo sob condições específicas: pinturas

\footnotetext{
${ }^{91}$ MAFFESOLI, Michel. A comunicação sem fim: teoria pós-moderna da comunicação. In: MARTINS, Francisco, MACHADO DA SILVA, Juremir. A genealogia do virtual. Porto Alegre: Sulina, 2004, p. 25.

92 SAUSSURE, F. Curso de lingüistica geral. Apud Kristeva, Júlia. História da linguagem. Lisboa: Edições 70, 2003, p. 298

${ }^{93}$ FLUSSER, Vilém. O mundo codificado: por uma filosofia do design e da comunicação. São Paulo: Cosac Naify, 2007.
} 
rupestres, organização de ossos e pedras, representações em obras de arte medievais, tudo traz consigo modos de tirar a humanidade do processo de alienação que, para Flusser, leva o homem a dar sentido ao mundo.

Os significados atribuídos ao celular são resultado da soma dos valores de uso e troca (falar, ouvir, fotografar e sua equivalência a outros bens), mais o valor sígnico (de acordo com sua sofisticação, seus equipamentos híbridos etc.) e o valor simbólico (aquilo que ele representa particularmente, individualmente pelo apreço atribuído ao bem $^{94}$ ). Têm-se, portanto, no equipamento híbrido, duas variáveis vinculadas ao material da vida social e duas outras ao cultural.

Canclini aponta que Pierre Bourdieu desenvolveu esta diferença entre cultura e sociedade ao mostrar, nas suas investigações, "que a sociedade está estruturada em dois tipos de relação, as de força, correspondentes ao valor de uso e ao de troca; e dentro delas, entrelaçadas com estas relações de força, há relações de sentido, que organizam a vida social, as relações de significação”. Para Canclini "o mundo das significações, do sentido constitui a cultura. ${ }^{95 "}$

\subsection{O usuário e os sentidos nos usos do celular}

Acredita-se na existência de duas condições não sobrepostas, mas em constante tensão, nas quais tanto os indivíduos quanto o objeto celular transitam: uma vinculada ainda à produção de sentidos a partir da moral, família, do Estado e da categoria social e de prestígio à qual se pertence (dada pelas estruturas modernas); a outra na busca pela velocidade, o imediatismo, o niilismo diante da ineficácia dos estatutos da modernidade. Os sentidos não escolhem a condição para se formarem, eles seguem os fluxos constantes que regem o avanço (físico, tecnológico, científico).

O telefone celular é um significante rico em suas hibridações -- que protetizam inúmeras tecnologias produtoras de sentidos -- transformando-se, portanto, em um espaço de significados, que, obviamente, não significa por si próprio: é representado a partir de um lugar (físico/simbólico) para que se

\footnotetext{
94 Baudrillard desenvolveu esses quatro tipos de valor em sua Crítica da economia política do signo. "Essa classificação de quatro tipos de valor (uso, troca, símbolo e signo) permite diferenciar o socioeconômico do cultural”, explica Canclini, "os dois primeiros tipos de valor têm a ver principalmente, não unicamente, com a materialidade do objeto, com a base material da vida social. Os dois últimos tipos de valor referem-se à cultura, aos processos de significação". (CANCLINI, 2005, op. cit. p. 41)

${ }^{95}$ Idem, p. 41.
} 
efetive. Dessa forma, o aparelho móvel pode ser significado, em maior ou menor grau, como um espaço em que se apresentam, por exemplo individualmente ou em conjunto - a condição econômica, o prestígio, a inclusão, a segurança, a vigilância, a conexão, o ócio ou, evidentemente, um meio de comunicação.

Essa significação depende de um conjunto de fatores constituintes do individuo e de suas construções culturais (ambientais, físicas, sociais e políticas). Em outras palavras, os sentidos são atribuídos ao celular graças não somente à temporalidade e à espacialidade na qual se apresentam, mas, principalmente ao conjunto de bens simbólicos acumulados pelo usuário em sua história constituída pela cultura (no sentido lato). Este usuário passa então à categoria de protagonista ${ }^{96}$ na relação com e pelo aparelho.

O usuário é o sujeito responsável por alçar o celular ao protagonismo, por atribuir ao objeto seus valores. Dessa forma, o telefone adquire prestígio como meio de comunicação por constituir um sistema no qual se deposita uma enorme gama de significados compartilhados, transformando-se em um mecanismo através do qual se realizam manifestações culturais (atendo-se à cultura -- no presente momento -- como um "terreno no qual todas as informações se originam, onde o consumo se efetiva e o sentido é produzido $^{97 ") \text {. }}$

Mas, afinal, o que significa o celular se se mantiver na esfera dos usos simbólicos? O acesso ao outro e a possibilidade de ser encontrado, em deslocamento, são duas características primárias do aparelho (criado para a conversação). Contudo, sua miniaturização, ou a diferenciação estética e por tecnologias, torna-o um elemento de posição social, determina graduações de status. O crescente interesse pela tecnologia, aliado à intensa distribuição e à

\footnotetext{
96 Este sujeito é ainda aquele que se manifesta a partir das condições hegemônicas da relação com os meios de comunicação, da dinâmica na negociação de poder em um tempo específico. Nada impede contudo que se caracterize este sujeito seguindo a proposta de Flusser de que "esse raro não-lugar (Umort) em que se pisa, ali onde são criadas as imagens, na tradição foi chamado de 'subjetividade' ou 'existência'. Em outras palavras: 'imaginação' (Einbildungskraft) é a singular capacidade de distanciamento do mundo dos objetos e de recuo para a subjetividade própria, é a capacidade de se tornar sujeito de um mundo objetivo. Ou ainda, é a singular capacidade de ex-sistir (ek-sistieren) em vez de insistir (in-sistieren). Esse gesto começa, digamos, com um movimento de abstração, de afastamento-de-si, de recuo." (FLUSSER, V. op. cit., p. 163)

${ }^{97}$ JACKS, Nilda. Querência: cultura regional como mediação simbólica. Porto Alegre: UFRGS, 1999, p. 57.
} 
queda do custo no valor do aparelho -- somados à proliferação das operadoras e à livre concorrência nos Estados liberais - efetivaram a banalização do médium portátil.

Graças à banalização, como visto na introdução, o celular é consumido em progressão geométrica, estando nas mãos de dois terços da população mundial até o final de 2008. Trouxe consigo ainda o processo de miniaturização de diversos mecanismos nele acoplados (daí um híbrido), e toda a carga que podem representar seus usos.

O celular passa a representar a condição de prestígio que o usuário ocupa diante de um grupo, ou o sentimento de inclusão digital desse proprietário; manifesta também expressões subjetivas diante do outro, quando se escolhem momentos a serem filmados e fotografados que possibilitam formas variadas de se relacionar. Escutar música ou rádio, jogar ou usar os mecanismos de agenda, entre outras funções, revelam os atributos relevantes do mobile para esse sujeito.

\section{Igualdade celular}

Aqui desenvolver-se-á a idéia de relações, de aproximação, de semelhança, processadas pelo uso do telefone celular. Através dela podem-se significar a igualdade econômica, cultural e simbólica em maior ou menor escala. Para isso parte-se do desejo de ter um telefone móvel ${ }^{98}$, dividindo essa vontade em duas instâncias:

1- Intenção

2- Efetivação

Cada uma dessas instâncias possibilita, ao menos, o reconhecimento de três motivações para que se conclua:

a) De compra: envolve a condição econômica e a possibilidade de manutenção do uso (créditos ou conta); a aquisição de status ou prestígio diante de um determinado grupo; as tarifas, promoções e benefícios com a aquisição; o interesse por determinadas

\footnotetext{
${ }^{98}$ Evita-se, desse modo, a estruturação das relações entre estado e operadoras e entre estes e o usuário, visto que foge do foco desta dissertação: a concentração na desigualdade a partir do simbólico nos usos do celular.
} 
tecnologias; a estética do aparelho; e a afinidade com a operadora (que pode ser trocada a qualquer momento).

b) De posse: a possibilidade de pagamento das contas ou inclusão de créditos; o status ou prestígio junto aos semelhantes e a sobreposição aos diferentes; o compartilhamento de ações e de conteúdos; o aproveitamento das tecnologias agregadas ao celular e a habilidade de manuseá-las; as significações concretizadas ou não.

c) De uso: limitação econômica ou não; a fala; o compartilhamento limitado ou não ao econômico e ao tecnológico; o conteúdo simbólico agregado ao híbrido celular e o seu desdobramento em sua posse; a concretização da semelhança e do sentido de igualdade.

Têm-se, portanto, as intenções de compra, de posse e de uso em uma ponta, e a efetivação da compra, da posse e do uso em outra, cada qual com seus significados correspondentes. Cabe enfatizar, então, o celular como um espaço através do qual se formam ambientes de simbolização (nem sempre concretizada) concomitantemente ao externo a eles. São espaços que simbolizam, inicialmente, semelhanças na posse e nos usos.

Operam-se então os conteúdos globais e locais acionados pelo usuário e toda a gama de construções históricas, sociais, econômicas, culturais e lingüísticas (e que aproximam o usuário aos sujeitos iguais significados) e que vão tornar-se mecanismos de mediação para a efetivação da relação com e através do objeto celular. São mediações híbridas que permitem articular distintos sentidos e se abrem às trocas simbólicas que ocorrem no glocal $^{99}$.

O celular carrega consigo uma densa e diversa carga de sentidos. Culturalmente, têm-se o celular como um significante composto por um conjunto de significantes; tecnologicamente tem uma variedade de híbridos tecnológicos e funções (jogos, música, rádio, TV, GPS, Mensagens); na esfera simbólica, aproxima, inclui, assemelha, denota evolução, pertencimento, subjetivação; sociologicamente, iguala, posiciona seu usuário em determinada "classe"; como meio de comunicação, conecta, compartilha, comunica.

99 Global e local, semanticamente fundidos - o glocal --, resume-se a um "bunker de acoplamento corporal e simbólico-imaginário entre o ser humano e máquina processado no lugar de acesso como ambiência representativa do contexto local e umbilicalmente vinculado aos conteúdos da rede como dimensão representativa do universo global.” (TRIVINHO, 2007, op. cit. p. 249) 
Simbolizar, assemelhar, igualar, conectar, são termos carregados também de antagonismos, pois a existência de um pressupõe seu oposto. Quando algo significa é porque agregou a insignificância, se assemelha, carrega o dessemelhante, a igualdade à desigualdade, a conexão à desconexão. Se a existência de um posicionamento produz seu oposto, e se esse oposto é a significação a partir de um espaço (lugar, classe social, ambiente, estrato), o celular, como oposto ao sujeito e às alteridades dele, transforma-se num lugar de produção simbólica, inclusive de desigualdade (em maior ou menor grau).

O celular torna-se um objeto ambivalente, reprodutor do sistema de consumo, quem sabe um fenômeno da indústria cultural que esconde interesses de corporações de tecnologias, como instrumento de vigilância, de manipulação de tarifas, de jogos de interesse e de disputa da esfera de poder do Estado.

Por outro lado, deslocam-se os olhares para a importância que ele adquire quando na mão das massas, da sociedade, do indivíduo, cidadão, receptor, ou qualquer categoria que objetive sua versatilidade. Busca-se reconhecer e interpretar desejos e necessidades que surgem, as práticas possíveis; e mais, pode-se vincular essas ações com o individual, o social, ou às massas.

\section{Desigualdade celular}

Algo, entretanto, está ocluso. Relações secundárias demonstram outros papéis do aparelho, quando vistos a partir de um observador externo. Controle e vigilância, exclusão, exploração econômica, necessidade de renovação tecnológica constante, são algumas das violências simbólicas que se camuflam no uso do mobile - passam despercebidas pelos usuários --. E a desigualdade (econômica, cultural e social) aparece como elemento proeminente diante da condição hegemônica do aparelho como meio de comunicação que se fincou de modo protético ao mundo civilizado.

Têm-se, destarte, um simbólico que opera aqui pelo que Pierre Bourdieu denomina habitus: uma estrutura estruturante que organiza "as práticas e a percepção das práticas", como também uma estrutura estruturada: divisão em 
categorias sociais que geram "o princípio de divisão em classes lógicas que organiza a percepção do mundo social ${ }^{100 "}$.

Este habitus então se organiza a partir do reconhecimento da diferença, ainda que seja ele também produto dessa diferença (e seja significante "classificante" - e significado - "classificado"):

Os estilos de vida são, assim, os produtos sistemáticos dos habitus que, percebidos em suas relações mútuas segundo os esquemas dos habitus, tornam-se sistemas de sinais socialmente qualificados - como "distintos", "vulgares", etc. (BOURDIEU, 2007, p. 164)

Para Bourdieu, grosso modo, importa a influência mútua a partir do processo relacional (entre grupos e indivíduos) e da vivência desse processo quando se atribui valor (simbólico) a determinados gostos, práticas e ações ${ }^{101}$. O autor opera ainda no campo da dominação e da disputa de poder -- que não se deve excluir do processo de avaliação no presente trabalho -- mas o interesse no conceito de habitus a esta dissertação dá-se pela valoração dos antecedentes do usuário na produção simbólica e ao fato de que esta representa "uma dimensão de todo poder, ou seja, outro nome da legitimidade, produto do reconhecimento, do desconhecimento, da crença em virtude da qual os personagens exercem a autoridade e são dotados de prestígio ${ }^{102}$."

O reconhecimento desse acúmulo-manutenção de bens simbólicos possibilita à pesquisa social a identificação de conteúdos representativos e sua significação para determinados grupos sociais. Isso torna-se visível, por exemplo, quando Bourdieu aponta a fotografia como um excelente referencial valorativo de classe, porque no momento em que se armazena em película, se imortaliza um momento, é quando se dá importância a ele ${ }^{103}$.

Dentro dessa perspectiva o telefone celular e os instrumentos que o compõem reproduzem a estrutura -- que é o significante das variadas esferas sociais, tecnológicas, culturais; e por outro lado o aparelho móvel pode também reproduzir os significados atribuídos a esta estrutura pelo sujeito que nela experimenta sua existência.

\footnotetext{
${ }^{100}$ BOURDIEU, P. Op. cit. 2007, p. 164.

${ }^{101}$ Com efeito, pode-se afirmar a influência de um apreciador de obras de arte (com habilidade e técnica) sobre um leigo que a observe, desde que ambos entendam o mesmo objeto como arte.

102 BOURDIEU, P. Apud CANCLINI, 2006, p. 72.

${ }^{103}$ Idem, ibidem p. 72
} 
Entende-se um significado na ação do usuário com o celular (fotografar, por exemplo) e outra significação externa a essa; o que essa ação representa diante de um contexto temporal-espacial (o que se faz com essa foto e o que ela representa externamente, para a relação)? e quando se afasta da prática para analisá-la como um fenômeno, quando se pergunta o que o sujeito quis dizer (a partir de sua carga cultural e simbólica) ao escolher reproduzir aquele momento? Isso indica modos de se posicionar socialmente, ou de se mostrar conectado, de articular relações com outras pessoas, de resgatar lembranças, de violentar, agredir, enfim, de transpor sua vida vivida para o espectro do aparelho, seja para si ou para partilhá-lo.

Os significados depositados no objeto celular, no entanto, são extremamente paradoxais. Enquanto afloram possibilidades infindas de usos a partir de seus híbridos e da habilidade de seu usuário em produzir bens simbólicos, ao mesmo tempo efetiva-se um modelo de servidão: pagar contas, atender ligações, ter, renovar e receber infinitamente músicas, envio de mensagens e outros conteúdos, ser encontrado, falar quando não se quer, estando em movimento dentro de espaços coletivos, metrôs, ônibus, reuniões, salas de aula.

\subsection{Celular e pós-modernidade ${ }^{104}$}

A hibridação na mobilidade é a característica fundamental do telefone celular, afinal sem esta ação o telefone e seus objetos seriam apenas aquilo que são a priori (máquinas fotográficas, rádios, podcasts etc.). $\mathrm{O}$ deslocamento a partir de células e a possibilidade de compartilhar produtos simbólicos em movimento se fundem a uma propriedade relevante da condição pós-moderna: o nomadismo ${ }^{105}$. "Todos nós estamos, a contragosto, por desígnio ou à revelia,

\footnotetext{
${ }^{104}$ Pós-moderno "designa o estado da cultura após as transformações que afetaram as regras dos jogos da ciência, da literatura e das artes a partir do final do século XIX”(p.3), por isso "a reabertura do mercado mundial a retomada de uma competição econômica ativa, o desaparecimento da hegemonia exclusiva do capitalismo americano, o declínio da alternativa socialista, a abertura provável do mercado chinês às trocas e muitos outros fatores, vêm preparar os Estados (...) para uma revisão séria do papel que se habituaram a desempenhar desde os anos 30, que era de proteção e guia, a até de planificação dos investimentos" (p.6 e 7). LYOTARD, Jean-François. A condição pós-moderna. Rio de Janeiro: José Olympio, 2000.

${ }^{105}$ A palavra nômade forma-se no latim nómades, derivado do grego nomás-ádos (de némein 'pastar'): individuo pertencente a uma tribo que se desloca a procura de pastagens para o gado; sinônimo de povo errante.
} 
em movimento", diz Bauman, "mesmo que fisicamente estejamos imóveis: a imobilidade não é uma opção realista num mundo em permanente mudança". No entanto, outras características se destacam também diante de uma ruptura com conceitos modernos: a tribalização ${ }^{106}$ em oposição à individualização; a dromocratização ${ }^{107}$ em vez da racionalidade e do planejamento; o pastiche ao invés da produção; o niilismo em lugar da crença.

As mudanças sociais, econômicas, culturais e tecnológicas operadas na última década do século 20 resultaram em uma condição inédita: a interdependência de todas estas instâncias para a manutenção de seu vigor e de sua sobrevivência diante da complexidade de um mundo economicamente globalizado, e internacional e transnacionalmente culturalizado. Daí a necessidade de aproveitar as tecnologias, com seu poder de armazenamento de informação e velocidade de intercambiar, para manter o ritmo então imposto.

Rompe-se com o racional, com o físico, e transpõe-se -- justificando a necessidade de velocidade -- à simulação de tempos e espaços. Não obstante interligam-se os sistemas em todas as instâncias do mundo civilizado, de modo a forçar parte da população mundial a depender dessas conexões. Essas são características da cibercultura ${ }^{108}$. Fenômeno que se apresenta através das

Poder-se-á conceituar o nomadismo enquanto um movimento e o nômade enquanto seu sujeito, portanto nem sempre são dependentes: o nomadismo é a ação, se dá no devir do mundo, nos movimentos que pregam a liberdade, na infinitude, enfim, em uma prática contrária ao sedentarismo (a fixação no território). Já o nômade é sujeito que se movimenta pelo e no nomadismo, dele se alimenta, por ele vive e luta. A ação de um marinheiro inclui-se no nomadismo, o marinheiro, entretanto, tem uma pátria, um pouso fixo e por ele sonha e para ele retorna; apesar de amar sua prática ela é apenas um dos seus modos de vida. Por outro lado, um cigano ou um tuaregue são nômades e praticam indistintamente o nomadismo, sem fixar-se, sem estabelecer sólidos vínculos com o espaço e dessa forma constroem o sentido de suas vidas: é da recusa à delimitação espacial que nasce o nômade, e da necessidade de deslocamento para renovação de práticas surge o nomadismo.

${ }^{106}$ Esta tratada por Maffesoli, como um movimento que surge antagonicamente à sociedade e suas organizações sólidas, fixas e propõe inclusive que os movimentos de tribalização (dos jovens em esferas urbanas por exemplo) demonstram "um estar junto". (MAFFESOLI, Michel. Tempo das tribos: o declínio do individualismo nas sociedades de massa. Rio de Janeiro: Forense Universitária, 2000)

${ }^{107} \mathrm{Ou}$ o mundo governado pela velocidade, proposto por Paul Virilio, e amplamente desenvolvido nas obras atuais de Trivinho. "A dromocracia cibercultural equivale ao processo civilizatório longitudinal fundado na e articulado pelo usufruto diuturno da velocidade digital em todos os sistemas da experiência humana." (TRIVINHO, E. 2007, p. 23)

${ }^{108}$ Apesar de ter conceituado cibercultura na introdução, seguindo as palavras de Trivinho, cabe aqui um outro conceito, não distinto, mas complementar. Para Rüdiguer a cibercultura (termo surgido nos anos 90) "é um conjunto de práticas e representações que surge e se desenvolve com a crescente mediação da vida cotidiana pelas tecnologias de informação e, assim, pelo pensamento cibernético e a civilização maquinística”. RÜDIGER, Francisco. Introdução às teorias da cibercultura. Porto Alegre: Sulina, 2007, p.183. 
interfaces ${ }^{109}$ dos objetos tecnológicos inseridos nos cotidianos; tecnologias que se renovam incessantemente, sem que haja tempo de moralizar as ações que ocorrem a partir dessas renovações, possibilitando (não efetivando) a inclusão de tudo e de todos, mas ao mesmo tempo excluindo àqueles que, por dromoinaptidão $^{110}$, não conseguem acompanhar esse sistema: violenta-os simbolicamente (por não estarem em conexão, por não possuírem atualizações tecnológicas, por não usufruírem dos mecanismos digitais).

Em contraposição aos densos conceitos modernos (e inacessíveis concretamente) de cidadania, emancipação, liberdade, igualdade, solidariedade e direitos, as palavras de ordem na cibercultura são a conexão, digitalização, velocidade, interação. O simulacro baudrillardiano, que aqui se inscreve nos produtos sígnicos que substituem o real se constituindo eles próprios em coisa, -- e assim superam o real e se tornam mais real que o próprio real -- parece mais acessível (pois aparentemente depende da aquisição de um produto celular), ainda que não o seja (pois necessita de um conjunto de valores, econômicos e culturais para se efetivar). Este é o mundo hiper-real, no qual as trocas simbólicas agora se efetivam.

O aparelho celular reproduz todas as características postadas neste item da dissertação em sua possibilidade de deslocamento, e por sua portabilidade junto ao corpo. Mas apesar de assumir o papel de prótese digital para diversos outros mecanismos tecnológicos, cabe reforçar, é no usuário que se processa o sentido. Esse sentido movimenta-se lentamente -- em descompasso com o mercado, com as operadoras, com o desenvolvimento das interfaces -- porque é um movimento natural, de evolução das capacidades humanas.

Sentidos não podem ser manipulados através de chips ou de atualizações tecnológicas, são manifestações de processos históricos sociais, individuais, imaginários, criativos e principalmente, avançam seguindo a ordem evolutiva do cérebro, a capacidade cognitiva e a inclusão no universo do reconhecimento.

\footnotetext{
109 “Criação de sons, imagens e palavras que podem ser manipulados numa tela”, segundo Johnson. O autor expõe ainda o conceito estipulado por ele como "cultura de interface": todo o mundo imaginário de alavancas, canos, caldeiras, insetos e pessoas conectados - amarrados entre si pelas regras que governam esse pequeno mundo. JOHNSON, Steven. Cultura de interface. Rio de Janeiro: Jorge Zahar, 2001, p. 4, 5 .

${ }^{110}$ Drominaptos são os indivíduos que não tem o domínio de lidar com instrumentos tecnológicos digitais velozes e portanto estão à margem do sistema de compartilhamento. (TRIVINHO, E. 2007)
} 
Em suma, é a cultura (as significações), em oposição à natureza, que vai guiar o estudo das práticas sociais que são exploradas na seqüência.

\section{Práticas culturais e democracia}

Inicia-se $o$ percurso que fundamenta a cultura nesta obra e, posteriormente, é apontado o que se entende como práticas culturais e como estas se apresentam na relação e nos usos do telefone celular.

Como posto por Raymond Williams, é possível o estudo da organização social da cultura em termos de suas instituições e formações. A complexidade da cultura no momento em que colocada como tal (ao ser incorporada por um sujeito que dela usufrui e a ela pratica), e de suas intervenções nos modos de agir de quem a processa, engloba uma gama infinita de sistemas que convergem, divergem, ou se ramificam em um mesmo momento.

Pode-se indicar o princípio do processo cultural no momento em que se compreende o mundo exterior através da linguagem, e, a partir dela se dialogue na busca de prazer, na fuga do sofrimento, no suprimento de necessidades e vontades, enfim, quando se organiza de maneira artificial os instrumentos codificadores e recodificadores dos sentidos. Com a sofisticação dessa linguagem (falada, escrita, musicada, gestualizada) ao longo do processo histórico, se demonstram níveis do desenvolvimento humano. Nesse ponto a cultura torna-se "um sistema de significação realizado ${ }^{111 "}$.

Os sistemas de significação acontecem em inúmeras esferas e, por vezes, de maneira bastante específica dependendo do sistema nos quais se inserem (político, econômico, familiar, educacional, religioso). Todos, entretanto, como assinala Williams, são elementos de um "sistema de significação mais amplo e mais geral: na verdade, um sistema social" que é agrupado em e agrupa todas as possibilidades disciplinares necessárias para a pesquisa dos fenômenos significados pela consciência humana.

A cultura aparece inserida em todos os sistemas com maior ou menor grau de relevância para que possa ser sistematizada e significada. Muito embora "uma moeda possa ser estudada como um sistema de signos específico", exemplifica Williams, "estudada também esteticamente (...) não há

${ }^{111}$ WILIAMS, Raymond. Cultura. Rio de Janeiro: Paz e Terra, 1992, p. 206. 
dúvida alguma de que, em todo o meio circulante típico, as necessidades e os atos de comércio e de pagamento predominam e, nesse sentido, o fator significativo, ainda que implícito está dissolvido ${ }^{112 "}$. Nessa analogia, para que a cultura predomine sobre outros fatores ela deve conter uma carga de história e de manutenção de tradições "geracionais" (de parentesco), posições sociais ou gostos, em outras palavras, de necessidades primárias socialmente desenvolvidas, que em certo nível sempre predominam (e que portanto não se esgotam com sua efetivação como na relação monetária).

Este estudo entende práticas culturais como ações para o acúmulo e distribuição de significados de uma pessoa, grupo ou sociedade, para a manutenção de suas tradições, vínculos e costumes em um tempo determinado. Dessa forma, os mitos, as histórias, as religiões, o conteúdo moral, bem como a organização legal e as estruturas componentes do Estado, são representações culturais em menor ou maior escala, independentemente da esfera (física, imaginária ou virtual) em que se processam.

Acredita-se, pois, na cultura como o lugar no qual se "contextualiza o sujeito" e os sentidos por ele produzidos. Atêm-se, portanto, ao modelo epistemológico postulado pelos estudos culturais, para atribuir sentido às práticas pelo celular. Desloca-se a relação entre o usuário e os instrumentos mediáticos (TV, rádio, celular etc.) para algo muito anterior ao momento de sua concretização, a saber:

- o desenvolvimento da linguagem;

- o local em que se vive;

- os princípios morais;

- o gosto;

- o grau educacional;

- as relações sociais;

- a condição econômica;

- a vontade, o desejo e a necessidade;

- a classe social

- a posição de status

- as ações que executam.

${ }^{112}$ Id. Ibid. p. 209. 
Enfim, a cultura aqui é, como definida por Hall, "uma soma das descrições disponíveis pelas quais as sociedades dão sentido e refletem as suas experiências comuns ${ }^{113}$ ". Obstante, cabe avançar ainda mais o conceito de cultura, e apontá-la também para a concretização da democracia ${ }^{114}$, no momento em que se aceita "o dar e tomar significados e o lento desenvolvimento dos significados comuns; isto é, uma cultura comum: a 'cultura' neste sentido especial 'é ordinária'”. Opera-se a cultura, portanto, em estâncias de acúmulo de conhecimento, em práticas sociais, bem como nas trocas simbólicas.

$\mathrm{Na}$ modernidade a cultura deteve atenção de antropólogos, filósofos, lingüistas e sociólogos que através dessa nomenclatura determinaram inúmeras ações e objetos. Entretanto, na contemporaneidade aparece extremamente vinculada à produção de sentido ${ }^{115}$ (representação de mundo motivadora para a existência). Este modo de ver se apóia principalmente no consenso da existência de pluralidades, e da necessidade de tolerância para que se construa um mundo em que a convivência seja possível.

Aqui a democracia, portanto, aparece em seu sentido mais amplo, como responsável pelo cruzamento de histórias distintas e para que conteúdos antagônicos, muitas vezes tensos, passem a conviver, a dividir espaços e territórios. A democracia se efetiva principalmente na cultura.

A democracia pretende um poder emanado do povo através de representações que possam dar-Ihe justiça, fato que não se consuma dentro de discursos totalitaristas e exclusivistas, como no capitalismo. Este sistema calcado no liberalismo econômico não cumpre seu papel, da mesma maneira que acusa seus antagonistas de não concretizar seus ideais.

Não se quer aqui atribuir valores hegemônicos ${ }^{116}$ à tecnologia móvel a partir da esfera dos interesses dos permissionários (o Estado), nem dos concessionários (operadoras), apesar de que em ambas hajam articulações

\footnotetext{
${ }^{113}$ HALL, 2003, op. cit. p. 135.

${ }^{114}$ Ao contrário do que se quis em períodos históricos anteriores, nos quais o objetivo era o de elitizar ao máximo esse termo.

115 Esses são estudos “voltados às práticas sociais enquanto sistemas significantes”, explica Sousa, "realizados com base na semiologia, buscando dar conta de como atuam na produção efetiva, material e corporal, individual e social no contexto histórico das significações." (SOUSA, Mauro Wilton. Recepção mediática e espaço público: novos olhares. São Paulo: Paulinas, 2006, p. 20)

${ }^{116}$ Veja-se hegemonia aqui como um poder negociado, concedido a determinados elementos durante um tempo dado. GRUPPI, Luciano. O conceito de hegemonia em Gramsci. Rio de Janeiro: Graal, 1978.
} 
importantes para que se efetivem relações nos usos do aparelho e dos significados $^{117}$ a partir dele. Estuda-se, sim, as possibilidades significadas através de mediadores tecnológicos. Dessa forma, percebe-se que como os mass media, o celular possui características valiosas para pesquisa.

\section{Comunicação e a efetivação da democracia}

Boaventura Sousa Santos aponta a renovação da teoria democrática como um caminho para a uma transformação social. Isso "implica, pois, uma articulação entre democracia representativa e democracia participativa", que conduz a uma redefinição e, principalmente, ampliação do campo político. $O$ espaço da cidadania enquanto prática social dentro da política liberal, segundo Sousa Santos, ficou confinado ao Estado, enquanto outras "dimensões da prática social foram despolitizadas, e com isso imunes ao exercício da cidadania $^{118 " .}$

Dessa forma a democracia no estado liberal só aparece no espaço político, da cidadania; os outros espaços políticos segundo a visão de Sousa Santos (o doméstico, o da produção e o espaço mundial) configuram também relações de poder e devem, portanto, ser "suscetíveis de democratização política". Em outras palavras, em cada um desses espaços devem existir lutas democráticas que possibilitem as relações de autoridade partilhada, repolitizando-os.

Concorda-se com Santos quando afirma que essa repolitização poderá "desocultar formas novas de opressão e de dominação, ao mesmo tempo em que criará novas oportunidades para o exercício de novas formas de democracia e de cidadania". A partir dessa visão deve-se perceber a democracia em seu sentido mais amplo: como responsável pelo cruzamento de histórias distintas, de conteúdos antagônicos, muitas vezes conflitivos, mas a conviver e a dividir espaços e territórios, mesmo ao se digladiarem por um. A democracia se dá não somente nas positividades, na sublimação ou nas artes, se efetiva ao partilharem-se práticas sociais e culturais.

117 A possibilidade da concorrência (aberta pelo Estado) é fator determinante para a seleção de uma operadora, por exemplo; bem como as promoções, preços e outros atrativos mercadológicos sejam relevantes. No momento em que esses merecerem destaque neste trabalho, serão apontados.

${ }^{118}$ SOUSA SANTOS, Boaventura. A globalização e as ciências sociais. São Paulo: Cortez, 2002, p. 270, 271. 
Muitas das conquistas democráticas no mundo contemporâneo deramse graças à maturidade da sociedade na relação com e através dos mass media. Agora engatinha-se à articulação de relações sociais (ou à efetivação da comunicação) através das tecnologias da informação, em especial pelo telefone celular. Em âmbito social têm-se a impressão de que a acessibilidade a esse aparelho micro-tecnológico equivale à democratização dos meios, como se o ter um objeto representasse o saber usá-lo (e para quê). Cabe esclarecer que sociação somente se dá quando as matérias com as quais a vida se efetiva "transformam a mera agregação isolada dos indivíduos em determinadas formas de estar com o outro e de ser para o outro ${ }^{119 " . ~ E ́ ~ u m ~}$ conjunto de interesses em direção a uma unidade para realizá-los.

A preocupação à qual se atem nesta obra é a valorização das características culturais e sociais da comunicação, pois, como explica Wolton, "não há teoria da comunicação sem uma teoria implícita, ou explícita, da sociedade $^{120 ", ~ b e m ~ c o m o ~ e ́ ~ i m p o s s i ́ v e l ~ d e s v i n c u l a r ~ a ~ c o m u n i c a c ̧ a ̃ o ~ d o ~ c u l t u r a l, ~}$ do social, da democracia e do simbólico.

\section{A comunicação em transição}

Para fugir da tecnologização do homem e da sociedade, e reforçar a comunicação como uma relação, Wolton aponta quatro fenômenos complementares para identificar a comunicação no mundo contemporâneo:

A comunicação é primeiramente o ideal de expressão e de troca que está na origem da cultura ocidental, e por conseqüência da democracia (...)

É também o conjunto das mídias de massa que da imprensa, ao rádio e deste até a televisão, perturbaram consideravelmente em um século as relações entre a comunicação e a sociedade.

Da mesma forma é o conjunto das novas tecnologias de comunicação que, a partir da informática, das telecomunicações e do audiovisual e interconexões entre estes fatores, vêm em menos de meio século modificar em nível mundial as condições de troca, como também de poder.

São, enfim, os valores, símbolos e representações que organizam o funcionamento do espaço público das democracias de massa, e de forma mais geral a

${ }^{119}$ SIMMEL, Georg. Questões fundamentais da sociologia. Rio de Janeiro: Jorge Zahar, 2006, p. 60
${ }^{120}$ WOLTON, 2006, op. cit. p. 15. 
comunidade internacional, através da informação, das mídias, das sondagens, da argumentação e da retórica. Quer dizer tudo o que permite às coletividades de se representarem, se relacionarem umas com as outras e de agir sobre o mundo. (WOLTON, D. 2003, p. 207)

Assiste-se a um movimento de transição no qual a modernidade esvazia-se por não ter efetivado suas propostas (cabe lembrar, a emancipação e o progresso através da razão). Dá lugar a uma estrutura desprovida de objetivos teleológicos, de meta-relatos para guiá-la, um momento calcado no niilismo, na velocidade para efetivação das relações, no enredamento de uma sociedade que perde a estrutura hierárquica e que está em processo de reformulação dos valores morais, éticos e culturais a partir do conjunto de fatores que surgem com a globalização (econômica), com a transnacionalização (cultural) e os híbridos que surgem a partir desta mélange.

Por outro lado, apesar da universalização cultural, têm-se também fenômenos contrários: um primeiro que surge do reforço dos laços sociais a partir do local; um outro emerge da reprodução universal do social, "o glocal nem exclusivamente global, nem inteiramente local, misto de ambos sem se reduzir a tais ${ }^{121 "}$.

Vive-se em um momento peculiar, no qual é possível armazenar tanto conhecimento e disponibilizá-lo de maneira acessível a uma grande parcela da população mundial, possibilitando, desse modo, a troca de conhecimento, sua renovação e o enredamento de seus usos em propostas interdisciplinares intercontinentais. Registra-se cada passo da civilização e das sociedades, não somente na esfera da cultura, dos ilustrados, dos românticos, mas também nas ações do popular, do ente anônimo, antes inexpressivo, um elemento pertencente à massa -- assim incognoscível.

Está-se no olho da transição de um bloco histórico que ainda não consolidou referenciais claros para um aporte seguro de conceitos (éticos, morais, culturais ou tecnológicos). Com efeito, não é possível nesse momento apontar para resultados certeiros, por exemplo, da condição moral à qual submeter-se-á a presente geração, dado que os mecanismos tecnológicos e as

\footnotetext{
121 Apesar do salto conceitual entre os termos global, local e o glocal, este se faz necessário para a compreensão do lugar a partir dos quais são constituídos os territórios de produção de sentido.
} 
representações, a partir do envolvimento com eles, gera reconfigurações das tensões, de conceitos, de aspectos normativos.

Em outras palavras, é extremamente difícil apontar caminhos morais, culturais, éticos, legais ou mediáticos, por exemplo, em um período complexificado pelo excesso de informação disponibilizada, como o dessa primeira década do século 21.

Alguns elementos, contudo, mantém-se essencialmente imutáveis (como o poder político, os interesses econômicos, ou as práticas da violência), ainda que a roupagem que thes seja dada confunda os sentidos. Os modos de simbolizá-los deslocam o debate para esferas profissionalizadas: os meios de comunicação de massa (canal de intermediação para a tradução dessas mudanças) aperfeiçoam-se para traduzi-los, mas sob modelos estandardizados -- reproduzidos na cadernização dos diários, em matérias constantemente assinadas por especialistas -- que acabam afastando-os do espaço popular.

Como que para lembrar a quem aposta na extinção simbólica do processo de modernidade, a desigualdade é um desses elementos, o urbano é seu principal espaço de difusão, e as tecnologias móveis seu mecanismo atualizado de extensão.

As significações, portanto, são produzidas e reproduzidas nos lugares de vida comum, no cotidiano, nos espaços de relações. Esses espaços são físicos, na vizinhança, na comunidade, nas sociedades das quais se imagina pertencer, eventualmente nos espaços nacionais; ou são construídos simbolicamente, pelos meios de comunicação, ou pelos mecanismos de informação.

O telefone celular passa a representar esses espaços pelas possibilidades que são ofertadas através de seus instrumentos: objetos que assemelham e separam, que incluem ao mesmo tempo em que incluem, que possibilita aproximação no momento que mantém o afastamento. Representa ao mesmo tempo um meio democrático (quando é acessível às maiorias), e autoritário (pelas limitações tecnológicas, econômicas e culturais).

Fato é que o mobile passou a significar algo de extrema importância dentro da sociedade atual. $\mathrm{O}$ que se retrata no capítulo a seguir é um recorte dessa significação; do abismo de desigualdade ao qual o celular expõe seu usuário, relativamente ao contexto em que se insere. 


\section{O CELULAR E SUA EXPRESSÃO SIMBÓLICA: TECNOLOGIAS SEMELHANTES EM USOS DESIGUAIS EM PRÁTICAS EMPÍRICAS}

Encerra-se o ano de 2008 com um panorama promissor para os usuários de aparelhos digitais móveis (notebooks, celulares, smartphones). Começam a despontar os mobiles, por exemplo, que possibilitam a audiência de TV digital, a transmissão de dados em alta velocidade ${ }^{122}$, o iPhone, o N95 da Nokia - no Brasil os celulares mais avançados neste momento - oferecem mapas (o GPS é pago), conexão em alta velocidade pela internet, checagem de e-mail, câmeras de vídeo em alta resolução, reprodução de músicas e rádio, entre outras coisas.

A TV digital (canais abertos), ainda em experiência no Brasil, já pode ser assistida em alguns modelos de aparelhos celulares; o trabalho pode ser atualizado através de pacotes do Office prontos para uso no mobile, em trânsito. Aumentam cada vez mais a potência das lentes, os mecanismos de armazenamento, as possibilidades de edição de texto e imagens a partir do material capturado pelo celular e a partir dele.

Com a protetificação do telefone celular junto ao corpo tem-se o fenômeno da transferência de sentidos entre usuários conectados e acessibilizados. Esses indivíduos, no entanto, diferem do todo não somente pela sua exclusividade sobre as ações desenvolvidas através do aparelho que o conecta, mas por obter diferentes papéis frente ao objeto mediático: é o emissor, o receptor, o usuário e, quando as limitações tecnológicas e econômicas permitem, também o produtor de conteúdos.

Hoje o celular possui inúmeros mecanismos e produtos que são utilizados mais ou menos intensamente. Por inserção tecnológica ou pela ordem de aparição da tecnologia, os usos do celular e de seus principais híbridos, com relevância para este estudo são:

- Falar ou conversar (80 minutos por mês em média individual*); $3,6 \mathrm{Mbit} / \mathrm{s}$.

${ }^{122}$ HDSPA (High Speed Dowlink Packet Acess) protocolo de acesso de alta velocidade de até 
- Enviar mensagens SMS (3 bilhões de mensagens trocadas no Brasil em $\left.2005^{*}\right)$;

- Agenda, calendário, despertador (60\% usavam o aparelho como agenda eletrônica, $58 \%$ consultam primeiro o celular ao relógio. 8 em cada 10 pessoas usavam o celular como despertador*);

- Jogar;

- Baixar ringtones;

- Fotografar (para $21 \%$ o telefone desbancou a câmera digital*);

- Ouvir rádio FM;

- Filmar;

- Navegar na web;

- Usar como podcast;

- Usar como GPS;

- Assistir filmes e vídeos. ${ }^{123}$

$\left({ }^{*}\right.$ em 2005, fontes: www.teleco.com.br; Yankee Group, Nokia, e operadoras Claro, TIM, Vivo e $\mathrm{Oi}^{124}$ ).

Com a aplicação da necessidade do usuário a cada tecnologia incorporada dá-se, então, um momento de passagem dos sentidos produzidos no mundo vivido para que a tecnologia distribua-os, a partir de qualquer espaço onde o sujeito se encontre. No uso da máquina fotográfica, por exemplo, um click e a foto feita digitalmente é reproduzida para um outro no tempo exato em que se processa uma emoção, um momento que se "considera digno de ser solenizado, como estabelece as condutas socialmente aprovadas a partir de quais esquemas percebe e aprecia o real ${ }^{125}$."

Acontece, pois, a reprodução dos sentidos para a máquina que os distribui. O celular, contudo, diferentemente da máquina fotográfica (que cria um proprietário da foto), permite a partilha instantânea do conteúdo. Agrega a ele o simbolismo no momento preciso, gerando alguns sentidos distintos: a sensação despertada pelo objeto fotografado, o desejo de compartilhar esse

${ }^{123}$ Essas informações servem como guia para o presente estudo, por apontar a dinâmica de tecnologias dispostas pelos fabricantes e operadoras de um lado, e dos usos e desejos apontados pelos entrevistados nas respostas do questionário aplicado.

${ }^{124}$ RYDLEWSKI, Carlos. 100 milhões de celulares. São Paulo: Revista Veja, Editora Abril, edição 1991, 17 de janeiro de 2007, p. 68, 69.

${ }^{125}$ BOURDIEU, apud CANCLINI, 2005, op. cit. p. 70. 
objeto com um outro, a seleção desse outro, a operação para envio com a certeza de que será efetivado (a crença no objeto) e a expectativa pela expressão do sentido daquele que recebe o conteúdo. Sentidos em duas vias para um mesmo sujeito através de sua obra, bem como atribuição de sentido a outros e à máquina.

O objeto celular passa de um instrumento igual para todos (pela disponibilidade tecnológica semelhante nos aparelhos e pela facilidade de aquisição), para um gerador de diferenças, porque adquire significados distintos ao ser inserido nos hábitos diários.

O que se percebe durante seu uso, é que o mobile não somente representa suas tecnologias e seus proprietários, mas também reproduz o espaço em que o usuário simboliza. O celular é claramente um reprodutor de desigualdades por ser uma extensão física do usuário (e, por conseguinte, do simbólico) e do lugar em que ele estabelece seus laços sociais, em que ele se relaciona. Pelo celular mantém-se a semelhança, os vínculos comuns e, portanto, quando esses vínculos são simbolizados pela posição social, cultural ou tecnológica que se ocupa diante de diferentes, a desigualdade como fato se efetiva.

Essa desigualdade, no século 21, não é ideológica nem hierárquica. É estabelecida por valores culturais, pelos direitos não reconhecidos, ou na luta pela democratização daquilo que se quer ser e ter. $\mathrm{O}$ alto número (acima de $80 \%$ no Brasil) de telefones pré-pagos, ainda que com incessantes aparelhos integrados, é um limitador para que se possa acessar ou incluir-se no universo digital, mas não é o único. A complexidade na operação, a limitação do conhecimento para manuseio das tecnologias, o analfabetismo funcional para a compreensão de complexos manuais de instrução, ou o desinteresse pelos equipamentos hibridados nos aparelhos, são alguns fatores que demonstram as desigualdades representadas nos usos.

A ambigüidade do celular - um objeto acessível tecnologicamente a todos, mas limitado no uso, como se verá na seqüência -- permite às interpretações de seus usos o trânsito entre a sociologia bourdieana (da manutenção da diferença para a conservação do prestígio através da posição simbólica em que se está classificado) e a antropologia da hibridação cultural 
de Canclini ${ }^{126}$ (quando vislumbra a "interação crescente entre o culto, o popular e o massivo"). Ambos enxergam o temor dos que concentram poder -hegemonicamente em cada esfera -- em perder sua força: de um lado a elite vê seus bens e modas popularizados rapidamente pelo mercado; de outro se inserem "mensagens massivas na esfera ilustrada".

\subsection{Celular: usos necessidades e desigualdades aparentes}

É fato que o celular se tornou um aparelho indispensável para os indivíduos. Em 2007, 21\% dos brasileiros preferiam perder a carteira e os cartões de crédito do que perder o telefone móvel, segundo Rydlewisk ${ }^{127}$. No mesmo ano, os pré-pagos já eram $80 \%$ do mercado nacional, metade dos usuários tinha entre 14 e 30 anos, oito em cada 10 brasileiros alegaram trocar o celular ao menos uma vez por ano.

Em 2008, no Brasil, com aproximadamente 150 milhões de aparelhos, só para se ter uma idéia da crescente importância depositada nesse objeto,

o estudo "Mobilidade Brasil 2008" da Ipsos revela também que $18 \%$ dos brasileiros se dizem viciados em seus celulares. As mulheres (21\%) e os jovens com idade entre 16 e 24 anos (23\%) são os mais viciados em seus aparelhos. Como se não bastasse, $5 \%$ dos respondentes utilizam mais de uma linha regularmente. Na classe $A B$, este número sobe para 17\%. (www.ipsos.com.br, acessado em 21 de novembro de 2008)

Com o surgimento da $3^{a}$. Geração de aparelhos, os chamados $3 G$ (apresentados na introdução desta obra), já no final de 2007, a velocidade de acesso foi multiplicada ${ }^{128}$. Navega-se pela internet em alta velocidade; é possível assistir TV digital aberta pelo aparelho (se a transmissão da emissora permitir); pode-se baixar músicas e jogos sem necessidade de sincronizá-los com o computador, bem como fazer videoconferência; é possível baixar vídeos com qualidade digital de áudio e vídeo; fica mais fácil o uso do Skype (para

${ }^{126}$ CANCLINI, Néstor Garcia. Culturas híbridas. São Paulo: EDUSP, 1998, p. 360.

127 RYDLEWSKI, Carlos. 100 milhões de celulares. São Paulo: Revista Veja, Editora Abril, edição 1991, 17 de janeiro de 2007, p. 68, 69.

${ }^{128}$ Em dezembro de 2007, "na Europa e no Japão, a velocidade de download no celular já chega a 3,6 Mbps (megabytes por segundo). No ano que vem (2008), deverá dobrar. No Brasil, a 3G deverá chegar com 1Mbps. É o suficiente para baixar um álbum de música em quatro minutos". FREITAS, Ronaldo et al. Para que serve a nova geração de celulares. São Paulo: Revista Época, Editora Globo, no. 501, 24 de dezembro de 2007, p. 40, 41. 
ligações gratuitas pela internet); existe a possibilidade do uso de dinheiro eletrônico (o que elimina os cartões de crédito), para isso basta passar o celular e digitar uma senha.

Lemos $^{129}$ descreve constantemente renovadas manifestações através do celular - limitadas, no entanto, às sociedades menos desiguais: o Dodgeball ${ }^{130}$, por exemplo, permite contato permanente entre usuários de SMS para que se identifique onde cada um está, e assim possam ser encontrados (uma espécie de GPS comunitário). Outra referência, dentre tantas, é o Imity ${ }^{131}$ : através dessa prática as pessoas que se comunicam pela web e não se conhecem pessoalmente se identificam, quando estiverem em um mesmo ambiente, através de sinais no celular, dessa forma estabelecendo as primeiras relações pessoalmente.

Fatores econômicos, contudo, são determinantes para que esse tipo de ação se propague. Uma pesquisa feita em 16 países, com 4.400 consumidores, pela consultoria KPMG, mostra que "mais da metade dos entrevistados afirmou considerar importante ler notícias, jogar games e trocar mensagens pelo celular, mas não quer pagar por isso", e mais, "quase $70 \%$ dos clientes afirmaram que mudariam de operadora se o serviço de multimídia subisse ${ }^{132 " . ~}$ Isso confirma que mesmo com inovações ou tecnologias de ponta, o celular somente se torna universal se não for cobrado o serviço.

Apesar das possibilidades de uso mais amplo serem acessíveis a poucos, por enquanto, o celular não deixa de gerar expectativas para um futuro próximo. Fato é que o mobile, no presente momento, não é referido mais como um elemento que proporciona posição de status. Ele aparece intensamente como uma prótese, algo adquirido pelo usuário para si próprio, para sua satisfação.

O celular substitui o cigarro de modo mais agressivo, afirma o escritor Jonathan Frazen, pois "dependências de um maço de cigarro por dia viraram

${ }^{129}$ LEMOS, André. Comunicação e práticas sociais no espaço urbano: as características dos dispositivos híbridos móveis de conexão multirredes (DHMCM). In: Revista Comunicação, Mídia e Consumo. São Paulo, vol. 4, no. 10, jul. 2007 b.

${ }^{130}$ Ver http://www.dodgeball.com

${ }^{131}$ Ver http://www.imity.com

${ }^{132}$ Idem, ibidem p. 42. 
contas mensais de U $\$ 100$. A poluição por fumaça, virou poluição sonora ${ }^{133}$." Mas não é só isso, Frazen enxerga o aparelho digital, no cotidiano novaiorquino, como uma reprodução da segurança materna:

(...) eu ficava sentado no metrô, observando outros passageiros abrirem e fecharem seus celulares, nervosos, ou mastigarem as antenas (que lembravam tetas e que todos os telefones tinham à época) ou então simplesmente segurarem firme seus telefones, como se tivessem agarrando as mãos de suas mães, e sentia compaixão por eles (FRAZEN, 2008, p. 4)

É evidente que o telefone celular tem potencial para aglomerar microtecnologias e processos digitais, e dessa forma pode oferecer cada vez mais possibilidades para que se estabeleçam relações (físicas, simbólicas, sócio-econômicas e comunicacionais) através dele. No entanto, se deslocar do universo tecnológico para o espaço físico, para o urbano, assiste-se ainda no século 21 à falta de saúde, de educação, habitação, empregos; perceber-se-á o crescente número de favelas, a falta de saneamento básico, a possibilidade de racionamento de água e limitação de outros bens, convivendo com espaços de opulência, de esbanjamento, de ostentação, tanto na questão econômica, quanto na simbólica.

Desse modo, as desigualdades estão sempre aparentes em sociedades distintas (como entre a novaiorquina, a européia e a brasileira) e dificilmente será efetivada semelhança entre esses espaços de diferenças. Por conseguinte, essas desigualdades estarão sempre refletidas em maior ou menor grau nas ações por mecanismos celulares, independentemente da posse de tecnologias semelhantes.

Algumas manifestações de desigualdade, no entanto, são percebidas em menor grau numa mesma sociedade (ainda que sejam gritantes, como na brasileira) através dos usos de meios de comunicação, pois os ambientes de produção e reprodução cultural são semelhantes (TV, jornais, grupos sociais, religiosos, sistema educacional, entre outros). A oferta de objetos tecnológicos se processa quase que ao mesmo tempo a grupos distintos (em lojas populares ou através de mercadorias contrabandeadas e pirateadas negociadas em camelôs, por exemplo). O celular reproduz todo esse circuito, e

${ }^{133}$ FRAZEN, Jonathan. Amor sem pudor. Folha de São Paulo. São Paulo, 16 de novembro de 2008. Caderno Mais, p. 4. 
o expõe na apropriação e reapropriação dos significados, que se dá na esfera de vida do usuário, em suas limitações, e de modo representativo no seu espaço comum.

É a tendência a essa reprodução, expressada em ações através do celular que vai se apresentar a seguir, através da pesquisa de campo. O ambiente selecionado para observar a disposição das desigualdades representadas através do uso do celular em uma sociedade desigual foi a cidade de Santos, no Estado de São Paulo - Brasil.

\section{Espaços empíricos de representações culturais}

Estabelecendo-se a cultura como produção de sentido para acúmulo e manutenção de bens culturais, étnicos ou simbólicos, cabe apontar a constituição dos espaços a partir dos quais os usuários de celular atuam. Entretanto, para este estudo interessa um lugar comum em que se processam as representações e se estabelecem diálogos e identidades, e a partir dele buscar interpretar a operação de ações através dos instrumentos hibridados no telefone celular.

Algumas características da cidade de Santos, litoral do Estado de São Paulo, e dos hábitos de seus moradores aproximam-na socialmente de regiões metropolitanas. Nessa cidade praiana, apesar de fisicamente próximos, praia e morro são culturalmente distintos pela idéia de desigualdade, dada pelas diferenças (e pelos diferentes contextos) em que estes ambientes foram formados e desenvolvidos.

A cidade nasceu nos morros, no século 16, pois eram lugares seguros contra ataques inimigos e piratas, como também proporcionava clima ameno, mais próximo do europeu (primeiros povoadores da região). Com o tempo deuse a ocupação dos terrenos a beira mar e sua valorização, em especial a partir do século 19, aliada à fase áurea do café exportado através do porto santista. Formaram-se, então, categorias de cidadãos abastados em seus casarões próximos à praia.

Os morros, contudo, mantiveram algumas tradições religiosas e as famílias residentes mais afetivamente vinculadas ao local. No século 20 , com o deslocamento da população rural para as cidades, e com os preços altos dos terrenos e imóveis na parte baixa da cidade, já valorizada pela proximidade 
com a praia, restou o espaço de morro para os escravos, as classes mais baixas, aos migrantes, e a uma parte dos portuários.

Neste século 21, na Baixada Santista, é através das simbolizações e ações relacionadas com a praia (pela proximidade com o ambiente, pelos objetos a ela relacionados, pelo bem-estar propagado, pelo culto ao corpo, ou pelo modo saudável de vida a ela relacionado) que se apresenta uma cultura de mar. A priori, crê-se que é nesse espaço-público democrático que se tem a oportunidade de estar em comunhão com os iguais a todo momento. Seja para o lazer, para a prática esportiva, para convivência, para atividades artísticas, intelectuais, ou para o trabalho, esse espaço que permite a união de areia com água salgada é refúgio de milhões de pessoas ao longo do ano.

No entanto, Santos têm uma característica distinta de outras praias, que não somente o fato de ser a cidade principal de uma região metropolitana (e com isso ser expressivamente urbanizada): seus sete canais de drenagem, que cortam a faixa de areia em direção ao mar, dividem não somente espaços, mas também estabelecem silenciosamente de maneira convencionada os limites de cada grupo. Nesses pontos se percebem as distinções entre jovens e idosos, turistas e moradores, atletas e sedentários, e, principalmente, ricos e pobres (o centro e a periferia). Na praia, em linhas gerais, se acentuam as desigualdades a partir dos espaços e horários selecionados pelos grupos para a chegada e sua permanência nela.

A facilidade de acesso a Santos (pela duplicação da rodovia dos Imigrantes no final do século 20) e o crescente deslocamento de paulistas da capital e do interior para as praias geraram uma supervalorização imobiliária cada vez mais seletiva, isso afastou o santista de renda média (portuário, petroquímico ou cosipano ${ }^{134}$ ) dos condomínios a beira mar. Esse morador, contudo, mantém-se próximo de seu ambiente, a praia -- e preserva hábitos e tradições relativas a ela --, do mesmo modo que convive de modo simbólico com um universo pretensamente elitista e cosmopolita.

A escolha do morro (qualquer um dos 19, divididos pelo bloco sólido que a cidade possui) como ponto de antagonismo à praia se dá primeiramente pela proximidade entre ambos (dentro dos $36 \mathrm{~km}^{2}$ de área urbana de Santos). Neles

\footnotetext{
${ }^{134}$ Funcionário da Cosipa, Companhia Siderúrgica Paulista, hoje Usiminas.
} 
verifica-se a presença de camadas menos abastadas da população (com acesso fácil ao espaço da praia), afastadas pelas diferenças, que se vêem em posição desigual a partir da sensação de distância da praia, e, por conseguinte, dos que usufruem de suas benesses. Esse afastamento, no entanto é extremamente simbólico, já que não se tem mais do que três quilômetros de raio, em média, para acessar o mar.

A praia, por conseguinte, aparece como ponto referencial desigual quando observada por seus símbolos econômicos, seus gostos, os gestuais a ela referentes, seus freqüentadores e algumas práticas esportivas elitistas (vela, iatismo, variações do surf e jet sky, por exemplo). É também um espaço democrático (pois se pode estar junto ali, na areia, no mar), inclusive culturalmente -- através das práticas relativas a ela -, e traz características comuns, como hábitos despojados, os esportes populares (futebol, vôlei, tamboréu e mesmo o surf) e o culto ao corpo. Tem-se a praia ainda como lugar de reunião, confraternização, de grandes shows gratuitos, de eventos de pequeno ou grande porte.

É dessa distinção que se estabeleceu o estudo de caso para a efetivação da pesquisa proposta, com vistas a identificar tendências dos usos do telefone celular por indivíduos vinculados à praia e outros aos morros.

Os lugares mistos como o centro da cidade, um ponto de passagem do habitante, em geral para compras e para o trabalho, foi pesquisado para observar se a tendência dos usos é reformulada quando o usuário está fora de seus ambientes de significação.

Para a efetivação deste estudo foi selecionado um grupo de alunos (voluntários) do primeiro ano dos cursos de Publicidade e Propaganda e de Rádio e TV, do Centro Universitário Monte Serrat, em Santos, para realizar a pesquisa de campo. Esses alunos foram escolhidos pela assiduidade, participação nas atividades curriculares e pelo histórico de notas. A disponibilidade para o trabalho e o grau de comprometimento foram fatores decisivos para a seleção.

O grupo foi orientado pelo professor de Teorias da Comunicação, responsável pelo presente trabalho. Enfatizou-se desde a importância sociológica do estudo, da responsabilidade acadêmica de cada um na precisão 
dos resultados, até a seriedade e a disciplina necessária para não interferir na resposta do entrevistado. O orientador participou também da coleta de dados e acompanhou presencialmente grande parte da ação dos entrevistadores.

Para a concretização desse percurso empírico, inicialmente elaborou-se um questionário com 18 perguntas fechadas e quatro abertas, e a partir dele foi realizado um pré-teste nos ambientes selecionados, com três grupos de pessoas (30 na praia, 30 nos morros e 15 no centro).

Após a verificação dos dados coletados, percebeu-se a necessidade de se ampliar para 29 o número de questões ${ }^{135}$. Nove questões fechadas apresentam o gênero e determinam a renda, ou definem o estrato econômico ao qual o entrevistado pertence; sete outras perguntas fechadas indicam o celular, as tecnologias, os híbridos, a marca ou a operadora do usuário; nove questões abertas indicam motivações, intenção e efetivação de relações (compra, posse e usos - ver o capítulo III, tópico 3.2) com o celular e através dele; por fim, três questões abertas foram elaboradas especificamente para os proprietários de celular pré-pagos. Foram entrevistados usuários de celular moradores de dois ambientes de significação (30 em cada local) e transeuntes residentes em Santos (15 pessoas) no lugar de passagem. De um total de 75 entrevistas, sete apresentaram informações conflitantes e foram excluídas.

Com isso, pôde-se aferir às tendências das práticas durante o uso do mobile. A partir dos resultados pôde-se mensurar os dados e analisar as representações simbólicas, estas vinculadas a espaços distintos de produção de sentidos, mediados pelo telefone, figurados na representação que os sujeitos têm de si em relação às alteridades.

\section{Celular: tecnologias semelhantes, usos desiguais}

A pesquisa de campo foi realizada entre os dias 6 e 10 de junho de 2008 em três espaços urbanos a partir dos quais as desigualdades sociais possibilitam modos diferentes de se perceber pertencente à cidade e, portanto, de lidar com instrumentos que tornam-se também parte desses espaços. Morro, praia e centro da cidade de Santos são recortes distintos de uma cultura principal: a de praia.

\footnotetext{
${ }^{135}$ Questionário está no anexo 1 do presente trabalho.
} 
As variáveis a partir das quais se estabeleceram as possibilidades de aferição da desigualdade e do simbólico são: a renda (que é um elemento importante de hierarquização social) e o local (espaço físico a partir do qual se produz sentido) ${ }^{136}$. Em outras palavras, a leitura dos dados concentra-se no que se tem e o que se ganha, juntamente com a posição que se ocupa no mundo, a partir do lugar no qual efetivam-se as significações, ao espaço que se pertence em relação a outro. O telefone celular não só é uma extensão desses locais, mas também indica e comporta outros, nos quais os sentidos são produzidos.

Em uma análise verticalizada, poder-se-ia afirmar que mais possibilidades existem para os abastados moradores da orla da praia, que possuem mais recursos financeiros, educacionais, e maior possibilidade de acesso às culturas de massa e erudita. Cabe lembrar, contudo, que o grande conteúdo das culturas globais circula hoje através dos meios de comunicação, e que as idéias, gostos e posições políticas, sobre o que serve ou não para a efetivação de laços sociais acontecem mais intensamente na família, na comunidade e nas relações mais próximas.

Trocas simbólicas e aquisição de bens de consumo atualizados se dão costumeiramente na região praiana (que concentra cinemas, shoppings, teatros, espaços musicais, clubes e hipermercados); ali o número de celulares pós-pagos é relativamente maior entre seus habitantes, e apesar de tudo, o que se vê reproduzido através dos usos do telefone móvel não é a hegemonia do poder econômico. Menos ainda o culto às tecnologias hibridadas ao aparelho.

A possibilidade de expor o conjunto cultural agregado, ou de apresentálo somado às práticas pelo celular, objetivando sobrepor-se intencionalmente a outras categorias, não se efetiva no discurso e nem de modo consciente entre os entrevistados da região de praia. Mas o discurso que se apresenta nas

136 Totalizaram-se, na abordagem definitiva 68 pessoas: 26 moradores da orla da praia, 27 habitantes do morro e 15 transeuntes no centro da cidade. Na abordagem por gêneros, a quantidade de homens foi levemente maior no morro, com 14 homens e 13 mulheres; na praia a diferença foi maior, com 16 homens e 10 mulheres; no centro foram oito homens e sete mulheres (ver tabela 7). Ressalta-se que o gênero não se configura como variável para o resultado da avaliação proposta.

Cabe lembrar que alguns dos resultados apresentados ultrapassam os números absolutos anteriores pelo fato de, não muitos, entrevistados possuírem dois ou mais aparelhos. 
situações de uso do celular, por exemplo, demonstram essa diferença. O item mais enfatizado pelos moradores da orla -- a preocupação com as situações de emergência demonstram a preocupação com a manutenção de bens simbólicos e de consumo (como quebra de veículo ou atender clientes ou pacientes).

Outro tópico que merece destaque é o fato de o uso do MP3 superar o de rádios FM como fonte de entretenimento entre os mais abastados. Ainda que o celular seja semelhante, ou possua os mesmos híbridos, os hábitos se manifestam através do aparelho.

As semelhanças entre os mobile, e dos dispositivos nele conexos, não impedem demonstrações de vínculos afetivos. Ainda que a maior parte dos proprietários de celular possua ao menos a câmera fotográfica hibridada, somente os mais ligados à comunidade, vão se ocupar em reproduzir e armazenar as fotos obtidas em outros dispositivos tecnológicos, para compartilhá-las. A camada com rendimento maior, nos espaços pesquisados (morro, praia e centro), demonstra não se preocupar em armazenar ou transferir conteúdos, bem como é a que mais os descartam. (ver gráficos 2, 3 e 4)

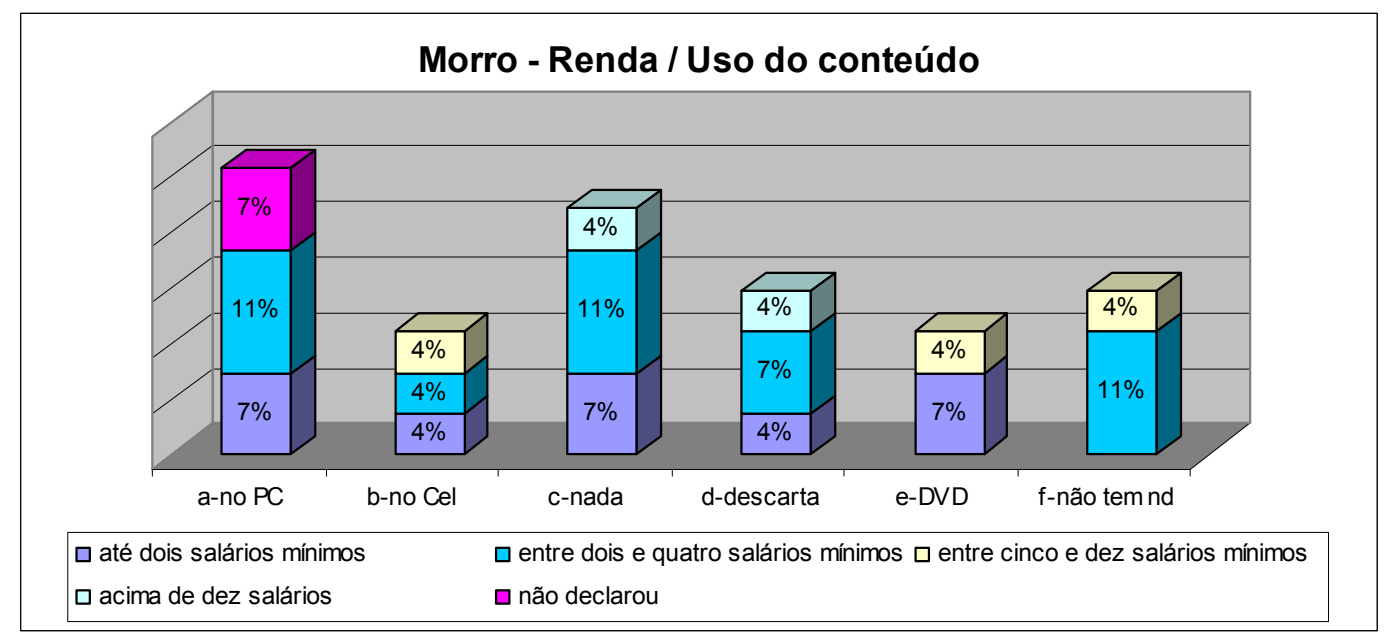

Gráfico 2: Morro, renda e usos do conteúdo

Fonte: GODOI, Christian. Celular: representações das desigualdades na mobilidade. São Paulo, 2009, 1 v. Dissertação (Mestrado em Ciências da Comunicação). Escola de Comunicação e Artes, USP. 


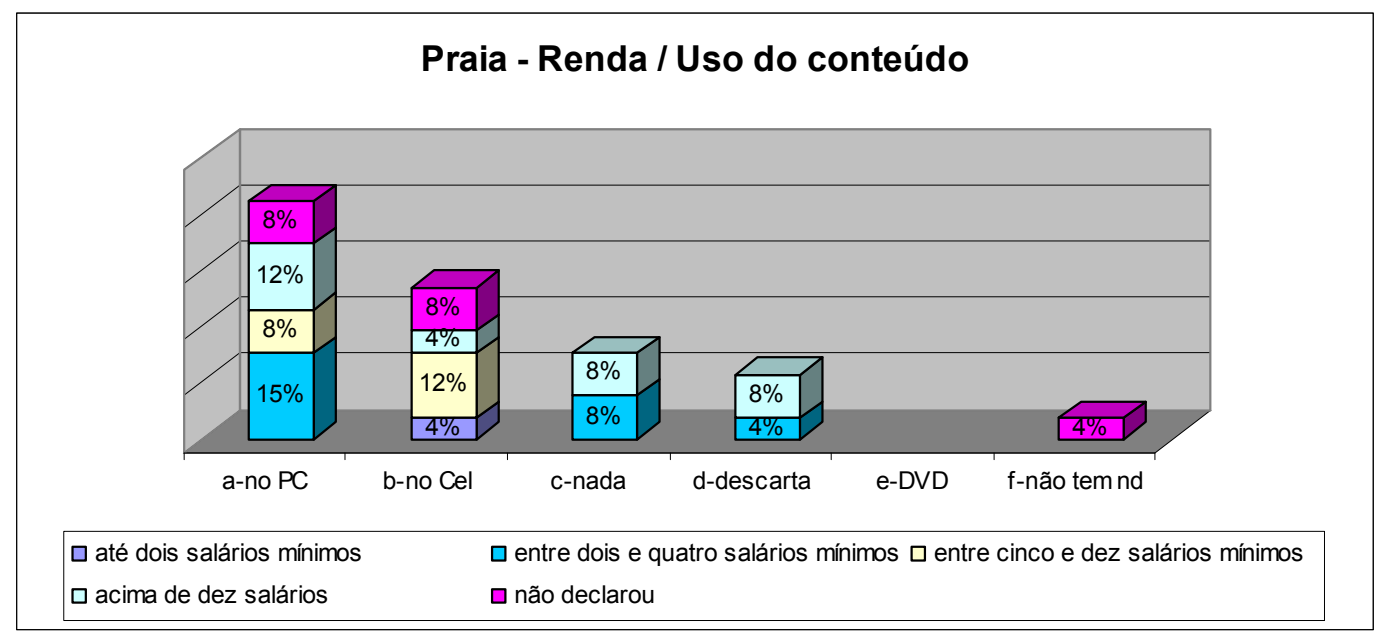

Gráfico 3: Praia, renda e usos do conteúdo

Fonte: GODOI, Christian. Celular: representações das desigualdades na mobilidade. São Paulo, 2009, 1 v. Dissertação (Mestrado em Ciências da Comunicação). Escola de Comunicação e Artes, USP.

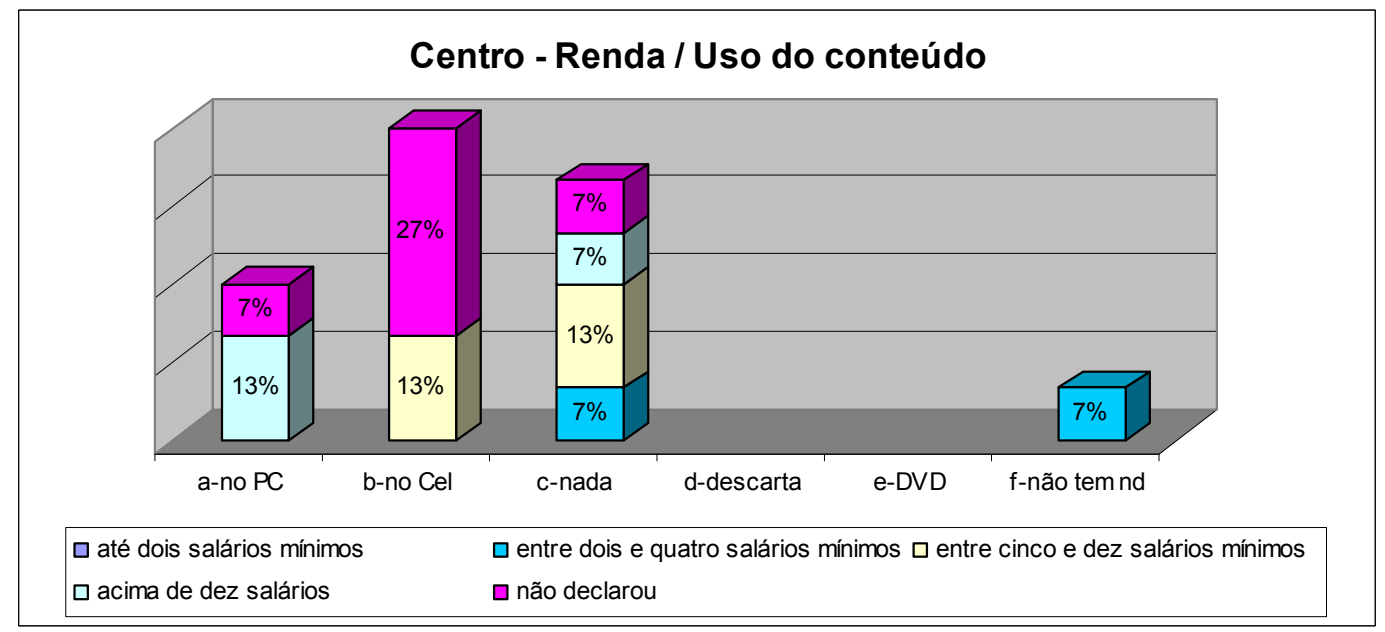

Gráfico 4: Centro, renda e usos do conteúdo

Fonte: GODOI, Christian. Celular: representações das desigualdades na mobilidade. São Paulo, 2009, 1 v. Dissertação (Mestrado em Ciências da Comunicação). Escola de Comunicação e Artes, USP.

Ainda que se evidenciam também diferenças entre as populações: os gestuais, as gírias (entre os mais jovens), os hábitos e os lugares de freqüência são sintomas claros dela. Mas o sentimento de desigualdade surge entre os moradores do morro, quando alguns se referem aos habitantes de praia como playboys, riquinhos ou o pessoal lá de baixo. Por outro lado, os habitantes da 
praia não têm o morro como referência comum (nem cultural, nem econômica, nem tecnológica). Em geral, contudo, a posse de objetos tecnológicos representa ascensão social, mas o celular não é apontado verbalmente em nenhum momento como significante de status.

Contudo, as desigualdades tornam-se nítidas principalmente quando o foco é na renda e no grau de escolaridade. Enquanto as atividades melhor remuneradas e os profissionais liberais se apresentam em número expressivamente maior na praia, no morro os trabalhos de nível técnico ou o desemprego são mais evidentes. Em ambos espaços ainda que o número de estudantes se mostre nivelado, os universitários aparecem unicamente na orla da praia.

O panorama anterior permite observar então que, quando se afirma utilizar o telefone celular para o trabalho, não se está referindo a um mesmo tipo de trabalho, mas diferentes atividades condicionadas, em geral, pela desigualdade presente nos espaços socialmente antagônicos. O resultado aferido no centro endossa também esse retrato. (tabela 8)

Quando se desloca para a propriedade de veículos como elemento de status, ou como representativo de ascensão econômica, deixa mais evidente a posição ocupada pelo morador da orla da praia. É ali que se concentram os veículos mais novos, mais potentes e de maior valor pela marca. Os moradores da área de morro possuem veículos mais antigos e motocicletas de baixa cilindrada. São veículos em geral para a locomoção ou para trabalho ${ }^{137}$.

Levando-se em conta que o mobile é uma extensão não somente do corpo, mas também do espaço, percebe-se que a semelhança do equipamento contrasta com os espaços estendidos e as ações desenvolvidas a partir deles.

${ }^{137}$ A questão da desigualdade que tem início com as possibilidades econômicas (e que pode ser percebida pelos bens acumulados) e se desenvolve para outras esferas (como a cultural e a de relações sociais) surge claramente neste estudo quando se opera nas variáveis renda/local. No morro a maior parte dos selecionados não possui, por exemplo, veículo automotor. Uma minoria fica restrita às motocicletas com 125 cilindadas (fabricadas entre 2005 e 2008), ou automóveis populares datados entre 1995 e 2005.

$\mathrm{Na}$ praia, 36\% dos entrevistados declararam não ter automóvel. Com renda a partir de 10 salários, 28\% têm veículos Honda e VW fabricados entre 2000 e 2008 . Foram declarados 15 automóveis e duas motocicletas (17 veículos no total, contra nove nos morros).

O centro reflete uma mistura entre os outros dois ambientes: a maioria não tem veículo, inclusive alguns com renda superior a 10 salários, e os veículos têm data de fabricação entre 1995 e 2005 . Motos também são novas (com data de 2008). No total foram declarados oito veículos (cinco carros e três motos). 
Um veículo utilizado mais como meio de transporte e menos como sinônimo de status, ou que é usado principalmente para serviços técnicos ou autônomos, tem como extensão tecnológica no celular, meios de suprir essas necessidades (de transporte - que não é papel do mobile; ou de manutenção dos serviços, o que se efetiva). Ter ou não veículo, é poder estender o status, o trabalho ou a necessidade ao celular. (tabela 9)

Quanto aos planos oferecidos pelas operadoras, os habitantes de todas regiões optam pelos celulares pré-pagos (tabela 10). Esses modelos superam os pós-pagos nas três esferas, apesar de os morros contarem com um número muito mais expressivo de usuários dos pré. Têm-se, portanto, o celular mais como instrumento de uso do que de status. E, principalmente: mais como instrumento de uso limitado pelo quantidade de créditos, ou pelo custo das ligações.

Essa semelhança oblitera uma outra desigualdade: aquela que limita a inclusão digital de modo integral aos usuários residentes em países com alto custo dos serviços prestados pelas operadoras. Aliás essa constatação se dá também quando se percebem a escolha por diferentes operadoras em cada ambiente. É uma seleção que acomoda as necessidades de uso às oportunidades promocionais. Com efeito, é o conjunto que envolve a mobilidade, a potência do sinal e a qualidade dos serviços, aliado às propostas de barateamento dos custos para uso, que determinam a escolha da empresa de celular. (tabela 11)

Para os que se deslocam por várias regiões do país, e fazem muitos interurbanos, por exemplo, uma determinada operadora pode oferecer promoções mais vantajosas do que aos que utilizam o aparelhos para se comunicar com a família em uma mesma cidade. A inexistência de cobrança de tarifa para ligações entre uma mesma operadora ou entre telefones celulares e fixos, tornou-se outro fator relevante para a escolha da empresa. Nos morros, por exemplo, os laços comunitários são mais intensos. Talvez pela proximidade entre vizinhos de casas, que se acompanham há gerações.

Os apartamentos, e a constante rotatividade de moradores das praias não aproximam os grupos ao ponto de aparentar uma comunidade. Ser do morro é um rótulo que o próprio morador do morro se dá como forma de diferenciar-se dos da praia. 

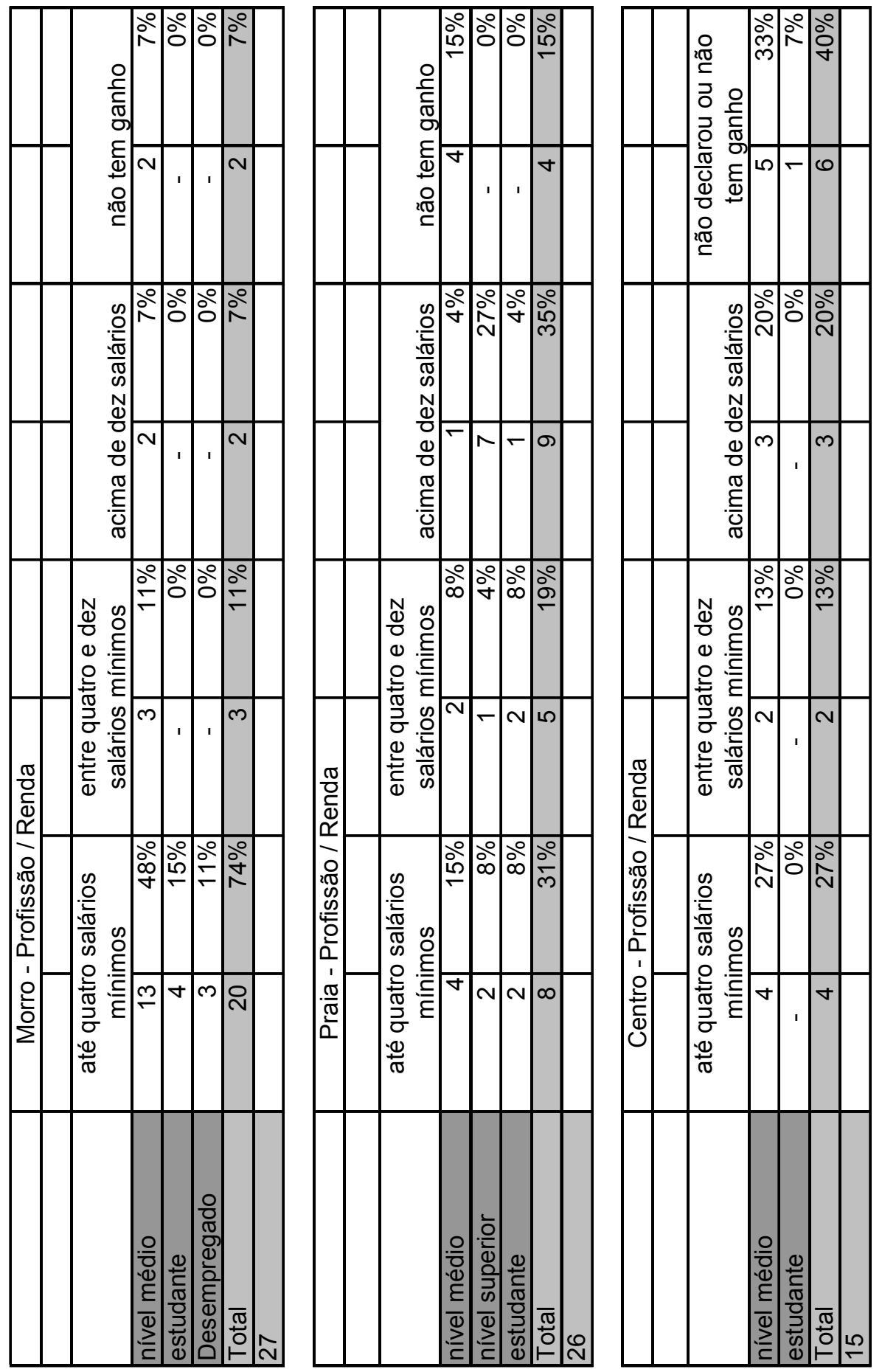

Tabela 8: Locais, renda, profissão

Fonte: GODOI, Christian. Celular: representações das desigualdades na mobilidade. São Paulo, 2009, 1 v. Dissertação (Mestrado em Ciências da Comunicação). Escola de Comunicação e Artes, USP. 

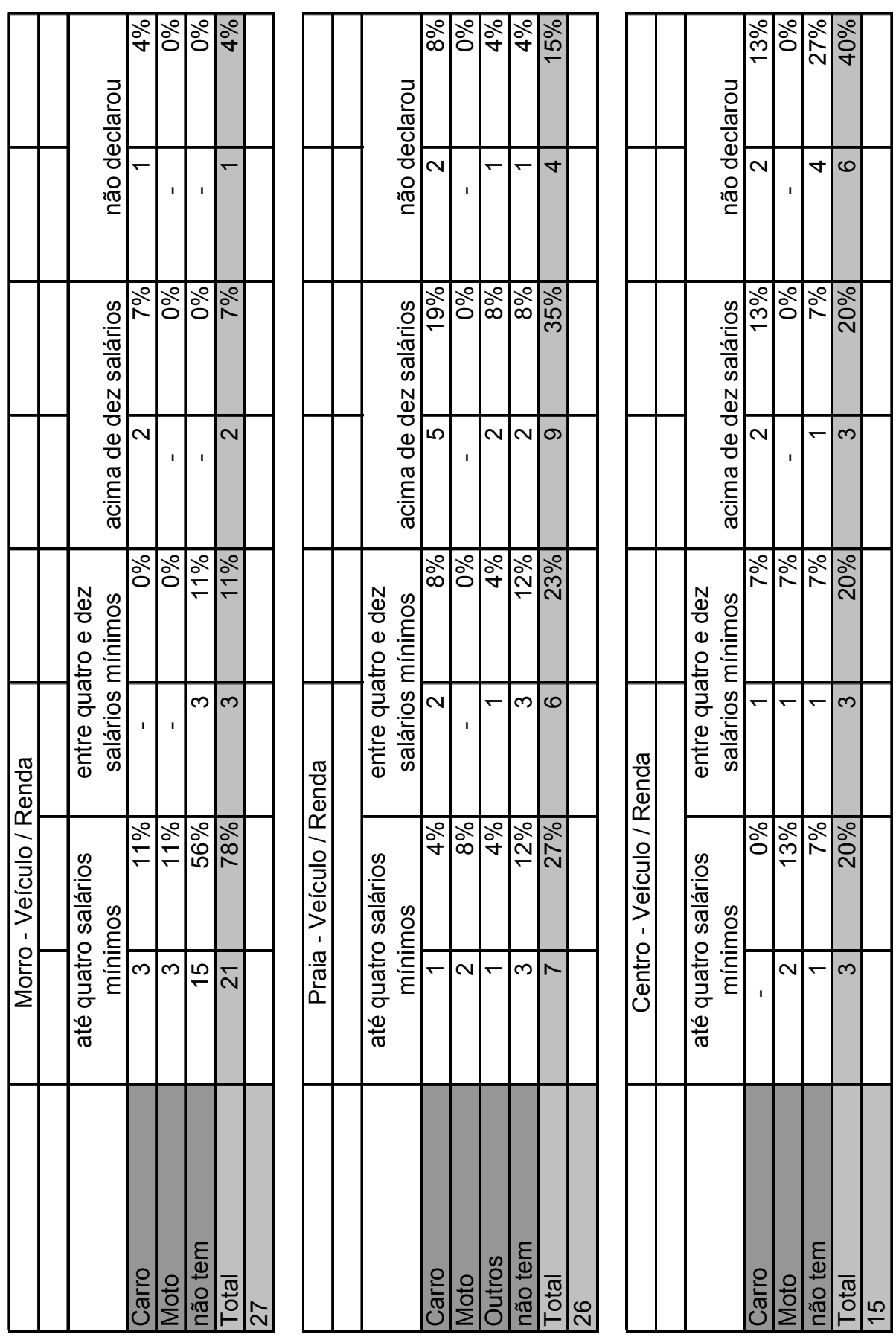

Tabela 9: Locais, renda, veículos

Fonte: GODOI, Christian. Celular: representações das desigualdades na mobilidade. São Paulo, 2009, 1 v. Dissertação (Mestrado em Ciências da Comunicação). Escola de Comunicação e Artes, USP. 


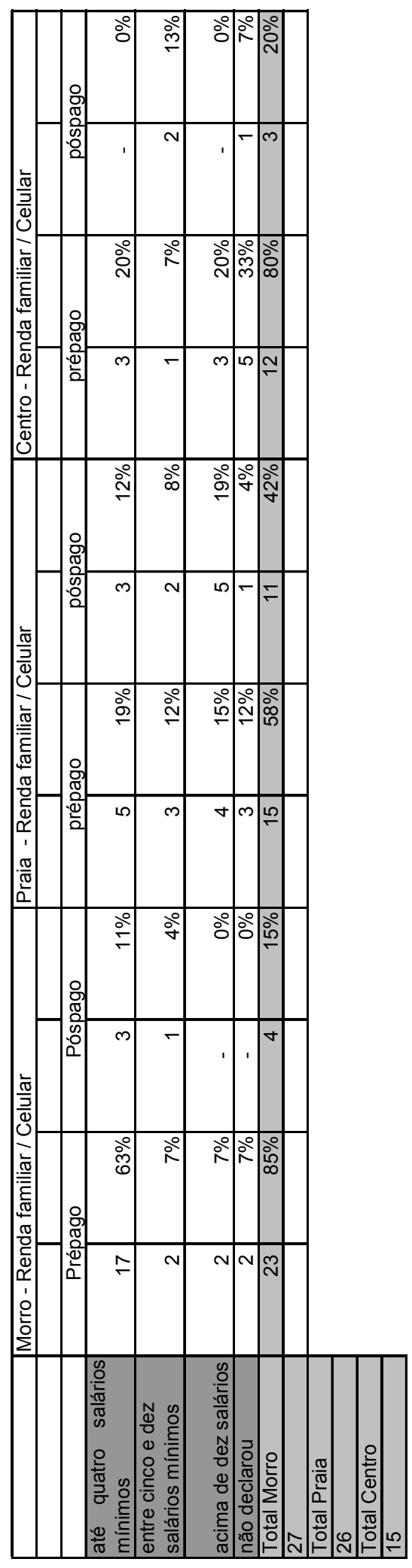

Tabela 10: Locais, renda, celular pré-pago e pós-pago

Fonte: GODOI, Christian. Celular: representações das desigualdades na mobilidade. São Paulo, 2009, 1 v. Dissertação (Mestrado em Ciências da Comunicação). Escola de Comunicação e Artes, USP. 


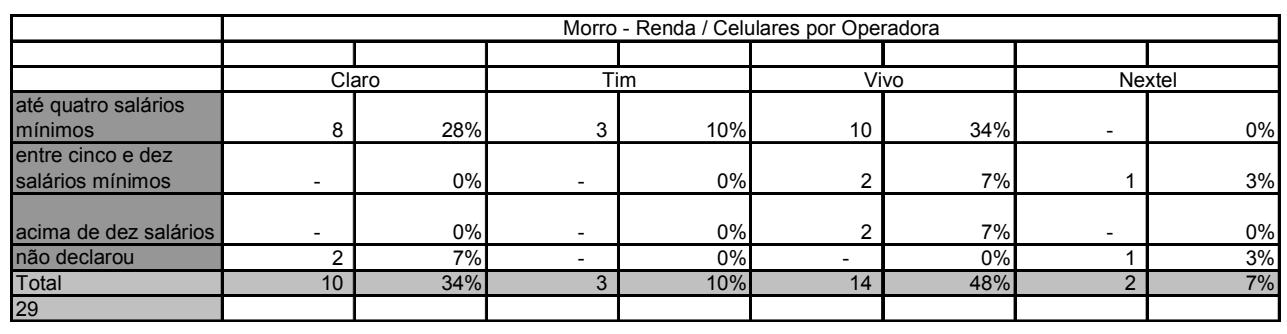

\begin{tabular}{|c|c|c|c|c|c|c|c|c|}
\hline & \multicolumn{8}{|c|}{ Praia - Renda / Celulares por Operadora } \\
\hline & \multirow{2}{*}{\multicolumn{2}{|c|}{ Claro }} & & & & & & \\
\hline & & & \multicolumn{2}{|c|}{ Tim } & \multicolumn{2}{|c|}{ Vivo } & \multicolumn{2}{|c|}{ Nextel } \\
\hline $\begin{array}{l}\text { até quatro salários } \\
\text { mínimos }\end{array}$ & 1 & $4 \%$ & 5 & $19 \%$ & 2 & $7 \%$ & 1 & $4 \%$ \\
\hline $\begin{array}{l}\text { entre cinco e dez } \\
\text { salários mínimos }\end{array}$ & 1 & $4 \%$ & 2 & $7 \%$ & 2 & $7 \%$ & & $0 \%$ \\
\hline |acima de dez salários & 3 & $11 \%$ & 5 & $19 \%$ & 1 & $4 \%$ & & $0 \%$ \\
\hline não declarou & - & $0 \%$ & 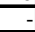 & $0 \%$ & 1 & $4 \%$ & & $0 \%$ \\
\hline não tem ganho & 1 & $4 \%$ & 1 & $4 \%$ & 1 & $4 \%$ & & $0 \%$ \\
\hline Total & 6 & $22 \%$ & 13 & $48 \%$ & 7 & $26 \%$ & 1 & $4 \%$ \\
\hline & & & & & & & & \\
\hline
\end{tabular}

\begin{tabular}{|c|c|c|c|c|c|c|c|c|}
\hline & \multicolumn{8}{|c|}{ Centro - Renda / Celulares por Operadora } \\
\hline & & & Deriur & 70 & 年 & & & \\
\hline & \multicolumn{2}{|c|}{ Claro } & \multicolumn{2}{|c|}{ Tim } & & Vivo & \multicolumn{2}{|c|}{ Nextel } \\
\hline $\begin{array}{l}\text { até quatro salários } \\
\text { mínimos }\end{array}$ & 2 & $13 \%$ & - & $0 \%$ & 1 & $6 \%$ & 1 & $6 \%$ \\
\hline $\begin{array}{l}\text { entre cinco e dez } \\
\text { salários mínimos }\end{array}$ & - & $0 \%$ & - & $0 \%$ & 1 & $6 \%$ & 2 & $13 \%$ \\
\hline acima de dez salários & 3 & $19 \%$ & - & $0 \%$ & - & $0 \%$ & - & $0 \%$ \\
\hline não declarou & 2 & $13 \%$ & 2 & $13 \%$ & - & $0 \%$ & - & $0 \%$ \\
\hline não tem ganho & - & $0 \%$ & 1 & $6 \%$ & 1 & $6 \%$ & - & \\
\hline Total & 7 & $44 \%$ & 3 & $19 \%$ & 3 & $19 \%$ & 3 & $19 \%$ \\
\hline 16 & & & & & & & & \\
\hline
\end{tabular}

Tabela 11: Locais, renda, operadoras selecionadas

Fonte: GODOI, Christian. Celular: representações das desigualdades na mobilidade. São Paulo, 2009, 1 v. Dissertação (Mestrado em Ciências da Comunicação). Escola de Comunicação e Artes, USP.

Fica explícita, pois, a diferença de posições econômicas entre ambos os ambientes, que evidentemente têm modos distintos de vida. Acontece, então, que nos morros são reproduzidas, em parte, as culturas de "vanguarda" dos habitantes da praia, posto que estes são os que primeiro têm acesso às novidades.

Com isso, se percebe a desigualdade econômica exposta nas possibilidades de uso dos celulares, em especial nos itens cobrados pelas operadoras. Curiosamente, nos morros o ambiente familiar e a tradição se impõem nas práticas através do celular: falar com a família é um item importante para o qual o mobile é usado, mas os modos de lidar com a família diferem dos de outras esferas. A preservação dos laços familiares supera em 
intensidade, não em número, o maior uso: o trabalho (pela manutenção da existência, não necessariamente pela aquisição do status em relação a outras esferas). Nos morros os usuários buscam a família.

$\mathrm{Na}$ esfera de praia, evidencia-se o celular principalmente para emergências e posteriormente para contato com a família. As ações da "classe média" através do aparelho demonstram suas prioridades na vida urbana: a garantia de preservação da segurança e do bem-estar - quando o celular é usado como mecanismo de apoio para momentos de conflito, saúde, de socorro, ou de vigilância. Ainda que a família apareça como motivação de uso em um segundo momento. O celular, na praia, serve para ser buscado, encontrado pelos entes. (tabela 12)

As diferenças de simbolização através dos usos do celular, dentro de uma sociedade desigual, são sutis pelo fato de os repertórios de reprodução simbólica serem muito aproximados. Desse modo as desigualdades não aparecem tão claramente na manipulação de objetos tecnológicos móveis. Por isso crê-se, aqui, que os desiguais digitais são mais desiguais em relação a outras sociedades, por não se perceberem em desvantagem em relação ao seu distinto.

Comparando as diferenças entre o ambiente de praia com o morro, o que se sente é que no segundo, a manutenção da dignidade dos direitos básicos da vida, a auto-preservação e a garantia de laços comuns (comunitários), são preocupações fundamentais. Na praia, a manutenção do status (econômico), ou o prestígio social são extremamente fundamentais (não necessariamente em posição de superioridade diante do morador do morro, por exemplo), por isso a dedicação ao trabalho.

\section{Celular como um espaço paradoxal em lugares antagônicos}

O objeto celular é extremamente paradoxal, pois enquanto afloram possibilidades infinitas de usos a partir de seus híbridos e da habilidade de seu usuário em produzir bens simbólicos, ao mesmo tempo efetiva-se um modelo de servidão econômica: pagar contas, ligações, músicas, envio de mensagens e outros conteúdos, atualização de tecnologias, infinitamente. 
Dessa forma, o mobile em sua banalização suscita a reflexão sobre o surgimento de distintos modos de exclusão, sobre o sentimento de solidão diante da multidão, a subordinação ao poder econômico e, principalmente, sobre práticas de violência (física e simbólica ${ }^{138}$ ) que se desenvolvem a partir de seus usos.

\begin{tabular}{|c|c|c|c|c|c|c|c|c|}
\hline & \multicolumn{8}{|c|}{ Morro - Renda / Situação de uso } \\
\hline & & & & & & & & \\
\hline & \multicolumn{2}{|c|}{$\frac{1}{\text { Trabalho }}$} & \multicolumn{2}{|c|}{ Família } & \multicolumn{2}{|c|}{ Outros } & \multicolumn{2}{|c|}{ Todas } \\
\hline $\begin{array}{l}\text { até quatro salários } \\
\text { mínimos }\end{array}$ & 7 & $23 \%$ & 8 & $27 \%$ & 6 & $20 \%$ & & $0 \%$ \\
\hline $\begin{array}{l}\text { entre cinco e dez } \\
\text { salários minimos }\end{array}$ & 3 & $10 \%$ & 1 & $3 \%$ & & $0 \%$ & & $0 \%$ \\
\hline acima de dez salários & 1 & $3 \%$ & - & $0 \%$ & & $0 \%$ & & $0 \%$ \\
\hline \begin{tabular}{|l|l} 
não declarou \\
\end{tabular} & 1 & $3 \%$ & 1 & $3 \%$ & - & $0 \%$ & & $0 \%$ \\
\hline Total & 12 & $40 \%$ & 10 & $33 \%$ & 6 & $20 \%$ & & $0 \%$ \\
\hline 30 & & & & & & & & \\
\hline
\end{tabular}

\begin{tabular}{|c|c|c|c|c|c|c|c|c|}
\hline & \multicolumn{8}{|c|}{ Praia - Renda / Situação de uso } \\
\hline & Emer & & & & $\mathrm{Ou}$ & & & \\
\hline $\begin{array}{l}\text { até quatro salários } \\
\text { mínimos }\end{array}$ & $\underline{2}$ & $6 \%$ & 3 & $9 \%$ & 6 & $19 \%$ & - & $0 \%$ \\
\hline \begin{tabular}{|l} 
entre cinco e dez \\
salários mínimos \\
\end{tabular} & 1 & $3 \%$ & 1 & $3 \%$ & 4 & $13 \%$ & - & $0 \%$ \\
\hline acima de dez salários & 5 & $16 \%$ & 4 & $13 \%$ & 2 & $6 \%$ & - & $0 \%$ \\
\hline não declarou & 2 & $6 \%$ & - & $0 \%$ & $\overline{2}$ & $6 \%$ & - & $0 \%$ \\
\hline Total & 10 & $31 \%$ & 8 & $25 \%$ & 14 & $44 \%$ & - & $0 \%$ \\
\hline 32 & & & & & & & & \\
\hline
\end{tabular}

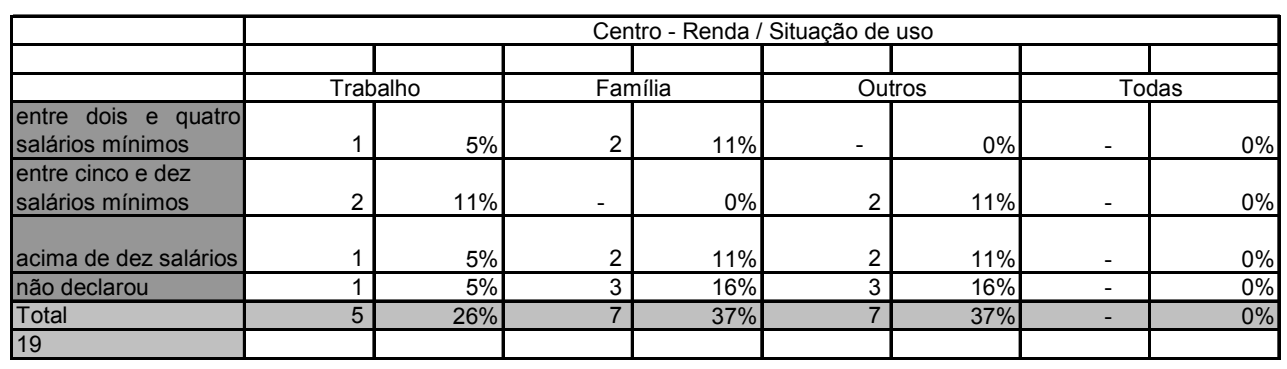

Tabela 12: Locais, renda, situação de uso

Fonte: GODOI, Christian. Celular: representações das desigualdades na mobilidade. São Paulo, 2009, 1 v. Dissertação (Mestrado em Ciências da Comunicação). Escola de Comunicação e Artes, USP.

${ }^{138}$ Para Bourdieu, “é enquanto instrumentos estruturados e estruturantes de comunicação e de conhecimento que os 'sistemas simbólicos' cumprem a sua função política de instrumentos de imposição e de legitimação da dominação, que contribuem para assegurar a dominação de uma classe sobre a outra (violência simbólica) dando o reforço da sua própria força às relações de força que as fundamentam e contribuindo assim, segundo a expressão de Weber, para a 'domesticação dos dominados'” (BOURDIEU, 2007 op. cit. , p. 11). Trivinho, pois, apresenta a violência simbólica como uma "violência imaterial, não física, levada a cabo, em geral, pela instrumentalização de signos, sem o concurso de agressões corporais diretas. (TIVINHO, 2007, op. cit. p. 93) 
Um exemplo de como essas violências se efetivam: em 2008 o Instituto Tecnológico de Massachussets (MIT) apresentou modos de prever a localização futura específica de um usuário através de dados estatísticos. Sob a argumentação de que isso possibilita, por exemplo, "mapear e entender o avanço da síndrome respiratória aguda grave, a sars" -- pois entendendo e mapeando o deslocamento o infectado é possível "compreender o mecanismo

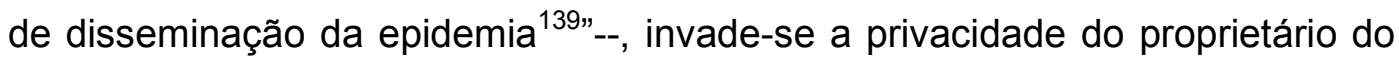
celular, violenta-se a liberdade de ir e vir, agora patrulhada por antenas de operadoras privadas.

O caminho de codificação e decodificação que move a tecnologia celular é extremamente longo: primeiramente tem-se o produtor do aparelho e de determinada tecnologia, sua adequação ao mercado, o acoplamento de outras funções que não somente a emissão e recepção de ligações (desde as mais simples como jogos, mensagens, câmeras de foto/vídeo e pod cast, às mais sofisticadas, como banda larga para web e GPS, além de receptores para HDTV - TV digital de alta definição).

Em um segundo momento a concessionária ${ }^{140}$ do serviço de transmissão de telefonia determina valores de ligação e suas promoções, bem como o serviço a ser disponibilizados em pré ou pós-pagos; finalmente dá-se a produção e distribuição de conteúdos específicos para cada tecnologia.

Deve-se ater ao fato de que todas as etapas dependem tanto de relações econômicas, como de aspectos políticos, de negociação. Dependem ainda de uma gama de conhecimento das atividades culturais e habilidades para desenvolvê-las digitalmente. Lembrar-se-á de que se está falando ainda da produção da tecnologia e da distribuição do serviço. No momento em que se deslocam essas etapas para a esfera do consumidor, forma-se o emissor/receptor/usuário.

O celular se transforma em um lugar de atuação que age inserido em um lugar de interpretação (de significação). Então se se verifica que o aparelho celular promove a aproximação é porque existe afastamento; se ele integra é set. 2008 , p.56

${ }^{139} \mathrm{O}$ celular como bola de cristal. Revista Veja especial tecnologia, São Paulo, ano 41, no. 2078, do autor.

${ }^{40}$ Não se deve esquecer da concessão do Estado, para que essas empresas possam operar. Nota 
porque enxerga-se alguma desintegração; quando apazigua é sinal de que uma violência se oblitera.

Percebe-se que as trocas simbólicas realizadas através dos usos do celular são um acúmulo das reproduções do mundo da vida, do cotidiano, das possibilidades econômicas, da democratização das tecnologias, do interesse pelo que é dado pelos meios de comunicação e de informação. A extensão da cidade e as possibilidades de relacionar-se com as mídias locativas de Lemos (indicadas no capítulo 1 deste estudo), em sociedades desiguais, ainda parecem distantes. A ciberurbe não se efetiva completamente, pois o universo enredado pela web não se concretiza gratuitamente, livre de ônus. O celular (ainda) não replica a ampliação de mundo que se dá na internet, e sim realiza a aproximação com um outro com o qual se quer estar.

Neste estudo se aponta a tendência de que a significação ao objeto é dada não somente pela necessidade de possuí-lo, mas também pelo direito de concretizar essa posse (como cidadão, como consumidor, como igual ou desigual, mas com direito de escolher que igual se quer ser). Retoma-se Danigno, quando afirma o novo modelo de cidadania a partir de sujeitos sociais ativos, que escolhem o que consideram ser seus direitos, e por eles lutam ${ }^{141}$. Esse reconhecimento ultrapassa a inclusão, o acesso, o pertencimento ao sistema. Afinal, "o que está em jogo é o direito de participar efetivamente da própria definição desse sistema, o direito de definir aquilo no qual queremos ser incluídos ${ }^{142 "}$.

\subsection{Significações da ação com celular}

Diferentemente da vanguarda criativa européia, oriental, ou norteamericana -- que utiliza os celulares para a apropriação dos espaços públicos (através de trocas de impressões sobre o urbano em dispositivos na própria cidade), que faz anotações eletrônicas de um espaço, "deixando sua marca com um texto, uma foto, um som ou um vídeo", conforme Lemos ${ }^{143}$, ou localiza e mapeia lugares ou objetos urbanos, joga, usando as ruas como "pano de

\footnotetext{
${ }^{141}$ DAGNINO, E. 2004, op. cit. p. 108.

${ }^{142}$ Idem, 109.

${ }^{143}$ LEMOS, 2007b, op. cit., p.24.
} 
fundo" -- o que se vê, em sociedades desiguais, é a reprodução crua de seu mundo vivido.

Observa-se aqui que, apesar do uso de operadoras distintas, tanto os híbridos quanto os usos que se faz deles são semelhantes. Fotografar e ouvir música tem importante significado para o usuário de celulares quando está em movimento ou no trabalho. Vigiar os familiares, dar satisfação do local onde se encontra, garantir segurança própria e cuidar dos seus entes, negociar, dinamizar os processos de trabalho. Tudo isso vincula o uso do aparelho celular ao mundo da família e do trabalho, relações sociais que se mantém ao longo da história (natural, biológica, afetiva e sócio-econômica), independentemente da condição moral, política, econômica, cultural, que é ofertada. No entanto, as motivações, os objetivos e contextos diferem e muito, pois resultam de modos diferentes de interpretação de mundo.

Laços sociais e por vezes a representação desses laços são retratados pelas câmeras fotográficas. No entanto, ao invés da importância em reproduzir "solenes" momentos bourdieanos, a facilidade de fotografar e excluir o material fotografado em digital (sem a necessidade de revelar, fazer cópias e comprar álbuns para expô-las), esvazia a significação dos retratos, ainda que não se deva ignorar a importância dada à fotografia como modo de estabelecer laços, reafirmá-los e compartilhar o mundo vivido.

Por outro lado, depois de ser usado para falar o segundo uso mais constante do celular é a câmera fotográfica. (tabela 13) Fotografar é uma rica expressão do estar junto, de poder demonstrar essa interação. Não importando-se com o fato de o conteúdo fotografado ser descartado imediatamente após a captação, ou se é transferido para outro suporte tecnológico, tornar-se-á relevante, sim, a importância dada em reproduzir o momento, de congelá-lo brevemente, e "curti-lo", sem a obrigação de grandes operações técnicas.

De modo geral, selecionando as variáveis renda e local, a pesquisa de campo aponta para os seguintes resultados:

a) No morro um público com renda de até quatro salários mínimos, que usa operadora Claro e a câmera fotográfica.

b) Na praia a maior parte dos entrevistados tem renda superior a cinco salários, mais da metade ganha acima de 10 salários. A operadora 
mais citada é a Tim, seguida pela Vivo, e a Claro. A câmera fotográfica também é o híbrido mais usado, mas o MP3 aparece com destaque.

c) No centro, $27 \%$ não disseram a renda, entretanto temos $60 \%$ dos entrevistados declarando entre quatro e 10 salários. A Claro é a operadora mais usada com quase $40 \%$ da preferência, e as outras aparecem empatadas com $20 \%$ cada. Dos entrevistados sete afirmam não possuir nenhum híbrido, o restante usa o rádio $\mathrm{FM} \mathrm{e} \mathrm{a}$ câmera fotográfica.

Em relação às sociedades européias, asiáticas ou norte-americanas, os grupos entrevistados para este trabalho são desiguais nos usos das tecnologias, não porque simbolizem unicamente a manutenção de diferenças para perpetuar seu status. Essas sociedades diferem porque estão distantes de interpretarem equitativamente o mundo. Consideram-se por vezes mais, ou menos, "desenvolvidas" (cultural, econômica e tecnologicamente). Nas sociedades mais desiguais economicamente e tecnologicamente, por exemplo, esperam-se novas modalidades de tecnologias e de bens de consumo se esgotarem em seus espaços de origem para que se possa usufruir delas, quando já estão ultrapassadas, gastas, démodée.

Ainda que as desigualdades estejam simbolizadas nos espaços físicos, traduzidas no ciberespaço, e no distanciamento entre diferentes, a criatividade ainda mantém os aparelhos ligados, através de atos surpreendentes, por vezes criminosos (como as ligações clandestinas de TV a cabo), mas que reproduzem modos de fugir de limitações impostas pelo mercado, pela atualização tecnológica ou pelo modelo econômico.

Em espaços com recursos monetários escassos, a expectativa constante pela ligação do outro revela a importância do celular para o usuário se sentir próximo, querido, parente. Não à toa o aparelho costuma ser chamado, pelos que só recebem ligações, de "pai-de-santo". Expressão que reproduz em palavras que remetem a uma tradição religiosa específica, o reconhecimento da desigualdade condenada pelo moderno, através de um instrumento da cibercultura, ou pós-moderno. 
Enfim, o mobile é um equipamento que está em processo, e vai oferecer infinitas pistas do complexo sistema de relações, reproduzido pelos meios de comunicação, que fazem do humano, ainda humano.

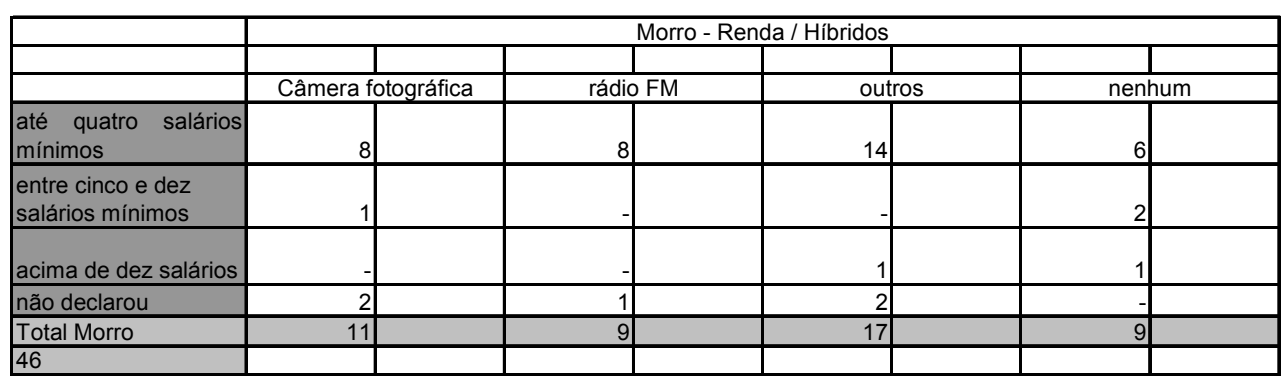

\begin{tabular}{|c|c|c|c|c|c|c|c|c|}
\hline & \multicolumn{8}{|c|}{ Praia - Renda / Híbridos } \\
\hline & & & & & & & & \\
\hline & \multicolumn{2}{|c|}{ Câmera fotográfica } & \multicolumn{2}{|c|}{ MP3 player } & \multicolumn{2}{|c|}{ outros } & \multicolumn{2}{|c|}{ nenhum } \\
\hline $\begin{array}{l}\text { até quatro salários } \\
\text { mínimos }\end{array}$ & 5 & $7 \%$ & 5 & $7 \%$ & 13 & $18 \%$ & 3 & $4 \%$ \\
\hline $\begin{array}{l}\text { entre cinco e dez } \\
\text { salários mínimos } \\
\end{array}$ & 4 & $5 \%$ & 5 & $7 \%$ & 10 & $14 \%$ & - & $0 \%$ \\
\hline acima de dez salários & 6 & $8 \%$ & 3 & $4 \%$ & 3 & $4 \%$ & 2 & $3 \%$ \\
\hline não declarou & - & $0 \%$ & 1 & $1 \%$ & 1 & $1 \%$ & - & $0 \%$ \\
\hline não tem ganho & 2 & $3 \%$ & 2 & $3 \%$ & 8 & $11 \%$ & - & $0 \%$ \\
\hline Total & 17 & $23 \%$ & 16 & $22 \%$ & 35 & $48 \%$ & 5 & $7 \%$ \\
\hline 73 & & & & & & & & \\
\hline
\end{tabular}

\begin{tabular}{|c|c|c|c|c|c|c|c|c|}
\hline & \multicolumn{8}{|c|}{ Centro - Renda / Híbridos } \\
\hline & & & & & & & & \\
\hline & \multicolumn{2}{|c|}{ Câmera fotográfica } & \multicolumn{2}{|c|}{ rádio $\mathrm{FM}$} & \multicolumn{2}{|c|}{ outro } & \multicolumn{2}{|c|}{ nenhum } \\
\hline $\begin{array}{l}\text { até quatro salários } \\
\text { mínimos }\end{array}$ & - & $0 \%$ & 1 & $4 \%$ & - & $0 \%$ & 2 & $9 \%$ \\
\hline $\begin{array}{l}\text { entre cinco e dez } \\
\text { salários mínimos } \\
\end{array}$ & 1 & $4 \%$ & 1 & $4 \%$ & 2 & $9 \%$ & 2 & $9 \%$ \\
\hline acima de dez salários & 1 & $4 \%$ & 1 & $4 \%$ & 4 & $17 \%$ & 1 & $4 \%$ \\
\hline não declarou & 1 & $4 \%$ & 1 & $4 \%$ & - & $0 \%$ & 2 & $9 \%$ \\
\hline não tem ganho & 1 & $4 \%$ & 1 & $4 \%$ & 1 & $4 \%$ & - & $0 \%$ \\
\hline Total & 4 & $17 \%$ & 5 & $22 \%$ & 7 & $30 \%$ & 7 & $30 \%$ \\
\hline 23 & & & & & & & & \\
\hline
\end{tabular}

Tabela 13: Locais, renda, tecnologias híbridas ao celular

Fonte: GODOI, Christian. Celular: representações das desigualdades na mobilidade. São Paulo, 2009, 1 v. Dissertação (Mestrado em Ciências da Comunicação). Escola de Comunicação e Artes, USP. 


\section{Democracia na mobilidade}

Comunicar-se em deslocamento (e por isso a rua aparece como principal lugar de uso - tabela 14), nos momentos de saudade, durante uma lembrança, para dividir uma idéia, para pedir auxílio. São práticas que refletem a importância da liberdade de se expressar no momento em que se entende necessário, com quem desejar, democraticamente.

Poder-se-ia dizer que a democracia (que não significa igualdade, mas sim direito de ser o que se quer ser, ter e de decidir o que se quer fazer) no celular surge com a possibilidade de possuir um aparelho, com valores acessíveis atualmente. Prova disso é o enorme número de telefones em circulação. Outro ponto no qual o mobile aparece democraticamente é na semelhança entre os aparelhos, pelos híbridos em comum (câmeras, bluetooth, rádio, MP3), ainda que alguns tenham mais capacidade de memória, lentes mais eficientes ou recursos diferenciados.

Percebe-se essa democracia também em alguns momentos pontuais na posse e no uso do objeto e em suas simbolizações. Apesar dos limitadores econômicos impostos pelas operadoras -- que representam não uma igualdade, mas um regulador da possibilidade de ter e de ser - o celular permite ao usuário dividir e solidarizar, vigiar ou libertar, enfim, dar e ser significado mais livremente do que os meios de massa. No celular tem-se um rosto, uma foto, uma música; tem-se um momento assinalado, um poema escrito, uma relação de nomes conhecidos.

Essa democracia, por outro lado, não se concretiza na esfera econômica: o número de telefones pré-pagos (50), contra 18 pós-pagos, verificado nesta pesquisa, manifesta -- se não a falta de capital para manter o aparelho ou o custo alto das ligações -- a falta de desejo do usuário em gastar suas economias na manutenção das chamadas. Esse fato praticamente elimina os usos de outros serviços cobrados, disponibilizados pelas operadoras.

Definitivamente, a desigualdade rompe essa democracia e fica aparente quando se observam os usos do objeto. São representações claras das posições de diferenças (locais e econômicas); aparecem como reprodução das situações e condições de vida dos próprios ambientes. Mesmo que os objetos hibridados sejam semelhantes, o que se reproduz com eles, o que se 
armazena e, principalmente, a importância dada a essa reprodução são antagônicas.

Vê-se isso quando os moradores da praia tendem a armazenar os dados captados pelo celular. Poder-se-ia afirmar que eles dão mais importância à informação capturada, ou possuem maior capacidade de armazenamento, sem que isso prejudique a eficiência do equipamento. No entanto, os moradores de morro reproduzem suas informações no DVD, como forma de preservá-las. O que pode representar limitações nos equipamentos, ou nos suportes para compartilhar essas informações (acesso à web, bluetooth, redes wireless).

Não há um sinal claro de que as representações do que é captado sejam maiores ou menores. Aparece, sim, uma restrição nas possibilidades de uso pelo custo de manutenção (pré-pagos são maioria), e pela limitação dos instrumentos do celular ou dos que interagem com ele.

A graduação do celular como mecanismo democrático, e de representação, simbólica depende do nível de importância dado pelo usuário a ele. Depende também da intensidade da presença do objeto em seu mundo, a ponto de transformá-lo em uma extensão protética do espaço, do corpo e do espírito.

Esse fenômeno fica flagrante quando se observam as respostas para a pergunta o que aconteceria se perdesse o celular ${ }^{144}$ ?

${ }^{144}$ Os resultados da presente pesquisa complementam e são complementados pelo estudo da Ipsos: “o Estudo 'Mobilidade Brasil 2008' da Ipsos revela como estes pequenos aparelhos estão mudando o comportamento dos brasileiros.

A multinacional francesa de pesquisa Ipsos realizou o estudo 'Mobilidade Brasil 2008' que busca, principalmente, compreender de que maneira o celular modificou a vida e o comportamento das pessoas e se ele trouxe novas atividades e costumes aos seus usuários. A pesquisa foi realizada em maio de 2008, foram 1.000 entrevistas com ambos os sexos, acima de 16 anos em 70 cidades e 9 regiões metropolitanas.

O Estudo 'Mobilidade Brasil 2008' revela que (...) existem pessoas que não conseguem separarse de seu celular nem por um segundo. Para a maioria das pessoas, um tempo suportável sem o aparelho é de, no máximo, um dia.

Um em cada cinco brasileiros se sente abandonado quando não recebem nenhuma ligação ou mensagem durante o dia. Especialmente entre as mulheres ( $23 \%$ contra $15 \%$ dos homens $)$ e principalmente os jovens.

Mais da metade dos respondentes usuários de telefone celular no Brasil realiza em média duas a cinco ligações de seu celular diariamente, sendo a maior concentração (20\%) na faixa das três chamadas diárias".

(www.ipsos.com.br, acessado em 25 de agosto de 2008). 
Nos morros apenas um entrevistado mostrou-se calmo diante de tal fato, e disse que compraria outro. Dois afirmaram que perderiam serviços. $O$ restante (25 entrevistados) afirma que ficaria louco, ou "que é como perder um órgão". O celular agrega algo presenteado (por outrem, ou por si mesmo), uma conquista, a inclusão no universo comunicacional, o encontrar e ser encontrado.

$\mathrm{Na}$ praia, onde o vínculo com o aparelho parece ser menor, seis entrevistados declararam friamente que "comprariam outro"; quatro disseram que perderiam serviços; três ficariam sem comunicação; o restante (13), apesar de representativo, atribuiu valor sentimental semelhante ao dos morros. Ou seja, $50 \%$ dos entrevistados perderiam o "órgão" celular.

No centro, o medo de perder a comunicação foi mais enfatizado. Alguns comprariam outro aparelho (os outros se dividiram entre sentir falta do aparelho e ficar arrasado). Isso talvez demonstre nesse ambiente a necessidade de usos para o trabalho e a capacidade de compra do que está empregado.

Quando se entende a desigualdade como simbolização das diferenças para a manutenção da posição social, e se acredita na simbolização como a efetivação dos conteúdos do mundo vivido de um sujeito; quando se percebem as práticas culturais como ações que representam um sistema significado, a partir do mundo partilhado e no qual se simboliza por consenso; quando se tem o telefone celular como um meio de comunicação (protético, digital e híbrido) móvel, tem-se então um mediador de relações democrático, ao lado de forças opostas (econômicas, institucionais e tecnológicas) que tensionam a efetivação do aparelho como tal, forças que impedem a concretização dessa democracia, da liberdade, tolhida pelas limitações impostas.

O celular, como percebido por este estudo apresenta certa tensão entre a liberdade tecnológica, dada pela acessibilidade, pelo deslocamento; e a impossibilidade de concretização da igualdade nos usos, limitados pelo econômico, pelo cultural e pelo político.

A desigualdade através do celular se efetiva tanto nas relações em uma mesma sociedade (ainda que de modo sutil), quanto em relação a outras sociedades, mais proeminentemente, quando transformam o telefone celular não somente em uma prótese do corpo, mas em uma extensão da cidade, da rua, do consumo e do simbólico. Algo que acontece em ambas as esferas, em 
maior ou menor intensidade, e que tende a se consagrar como um fenômeno universal, para o mal ou para o bem, sempre relativamente.

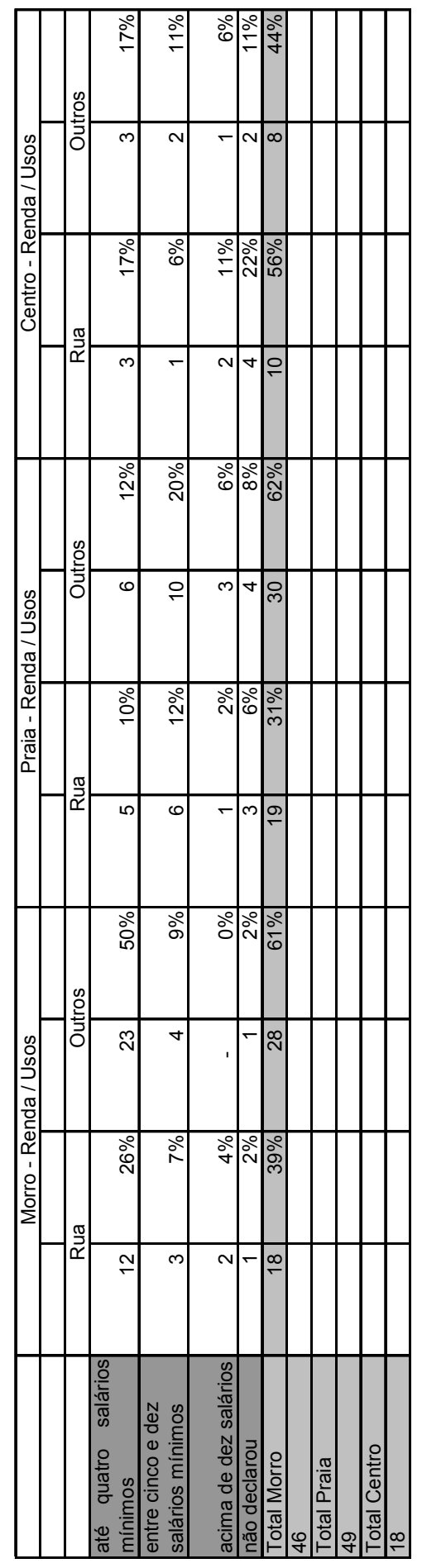

Tabela 14: Locais, renda, locais de uso

Fonte: GODOI, Christian. Celular: representações das desigualdades na mobilidade. São Paulo, 2009, 1 v. Dissertação (Mestrado em Ciências da Comunicação). Escola de Comunicação e Artes, USP. 


\title{
V. CONSIDERAÇÕES FINAIS
}

O celular está nas mãos de parte significativa da população mundial. Nos grandes centros urbanos representa tanto formas de manifestação e interatividade das vanguardas tecnológicas, quanto instrumento de sociabilidade dentro de grupos específicos. Possibilita um espectro infinito de significados quando dentro do universo do usuário. Mas representa também a perspicácia das estruturas políticas e econômicas, que se beneficiam da exploração dos serviços e das informações disponibilizadas através da transmissão de informação, dos diálogos, das mensagens de texto.

Pelo celular, nas grandes cidades, se esquadrinha o posicionamento do usuário, invadem-se os espaços privados, expõe-se constantemente sentimentos, desejos, intimidades - publicamente.

\begin{abstract}
Refiro-me ao hábito - incomum há dez anos, mas hoje onipresente - de encerrar conversas ao celular gritando "amo você". Ou ainda mais opressivamente e exasperador, "eu te amo!" (...) A própria essência do que é tão desagradável no celular como fenômeno social é que ele possibilita e incentiva o ato de impor o pessoal e individual ao público e comunal. (FRAZEN, J. 2008, op. cit. p. 4)
\end{abstract}

O silêncio torna-se proibitivo, as conversas acontecem em todo lugar, na frente de qualquer um. E paga-se para isso. Mas é praticamente impossível se imaginar sem comunicação num mundo violento, ou em que as oportunidades de trabalho são escassas - portanto não pode ser desperdiçada nem por um momento --, ou no qual os pais, os filhos, as esposas estão a mercê das vicissitudes cotidianas.

O celular está também nos campos de arroz da China, nos campos de petróleo árabe, nas tribos clássicas da África, em mãos de traficantes latinoamericanos. Presidentes, imperadores, estivadores e mendigos, o telefone celular está nas mãos de todos, em cada canto, com mais ou menos recursos, pré-pagos ou pós-pagos. Ele está disponível em lojas especializadas, seus serviços são prestados em bancas de jornais, farmácias e supermercados.

Reforça-se, contudo: tudo tem um custo. Na esfera econômica o celular proporciona mais possibilidade aos abastados. Atualização tecnológica constante, uso de internet, interação com outros dispositivos digitais são uma 
realidade para quem pode pagar por isso. O celular transforma-se em TV digital por assinatura, em cartão de crédito, ou em vitrine virtual em banda larga. Mas existe outro lado.

Carrinheiros desfilam seus mobiles enquanto transitam suas carroças lotadas de papelão. Jovens viciados em crack encomendam a droga pelo telefone celular, pedófilos compartilham fotos pornográfica de crianças. Donasde-casa e os estudantes limitam-se às possibilidades de uso por falta de créditos. Analfabetos não conseguem decodificar os instrumentos que compõe o aparelho, pois não compreendem os manuais.

A velocidade do mundo atual aliada à necessidade de competência para manusear eficientemente os dispositivos hibridados no telefone celular, permite a poucos uma inserção eficaz no mundo digital através do mobile. Às maiorias fica o rebotalho, o resto dessas possibilidades. Suas limitações se escancaram sem que sejam percebidas, afinal o celular passa a sensação de inclusão. Terse-ia incorporado um instrumento que, como nenhum outro, carrega a significação de uma falsa consciência, "para a integração fictícia da sociedade no seu conjunto, portanto, à desmobilização das classes dominadas ${ }^{145 ",}$, se se utilizar o pensamento bourdieano. E aí se percebe a raiz da desigualdade, como representação da posição ocupada diante das diferenças.

Mas quando se desloca aos espaços locais -- e à relevância que eles desempenham na formação da cultura, do universo simbólico -- se compreende que não é somente a dominação, a exploração, ou a disputa de poder que está em jogo. Os laços afetivos, familiares (ainda que carreguem também disputas políticas e hierárquicas) e as relações na comunidade, reafirmam o lugar social ocupado pelos grupos, mas dessa consciência brotam as reivindicações, sejam verbalizadas, sejam expressas em ato ${ }^{146}$.

Este estudo apresentou um modesto panorama dos usos através do telefone celular em uma sociedade específica. Ou melhor, forneceu a

${ }^{145}$ BOURDIEU, 2007, op. cit. p. 10.

146 Após a primeira quinzena de maio de 2006, dezenas de pessoas (entre suspeitos de ligação com o crime organizado, policiais, bombeiros e cidadãos) foram mortas a tiros. Nenhuma novidade, não fosse o fato de as ordens de ataque terem sido dadas através de telefones celulares, de dentro de presídios, por líderes do PCC (Primeiro Comando da Capital - organização criminosa centralizada no Estado de São Paulo). Com efeito, dessa forma articularam-se inúmeras células terroristas em todo o estado, fato esse culminando ao longo do ano numa (suposta) ameaça das atividades comerciais, empresariais, políticas, religiosas de grande parte das cidades. (sobre o assunto, ver GODOI, C. 2008, op. cit.) 
possibilidade de refletir sobre a relevância do espaço comum, no qual se dá o cotidiano, como fonte imperativa de significação: ainda que os instrumentos hibridados no aparelho possibilitem a navegação pelo ciberespaço, o que se quer é poder compartilhá-lo no espaço de vida.

É significativa a necessidade de preservar-se ligado à família, mesmo que o rádio ou o MP3 distraiam a atenção do usuário. O lazer, disfarçado nos instrumentos tecnológicos do celular, não se impõe sobre a importância do trabalho para certas categorias que dele necessitam. Os retratos, que poderiam deslocar-se da esfera comunitária para outros olhares da cidade, das gentes, do mundo, continuam focando os amigos, os parentes, àqueles que se quer presentes.

Não ignora-se, claro, que existem exceções: artistas digitais que surgem, poetas guiados pela limitação de caracteres, fotógrafos e cinegrafistas amadores que, vez ou outra, utilizam o celular como forma reivindicação, de denúncia, de manutenção da segurança. Mas ainda são exceções.

O telefone celular é ambíguo também quando permite que se aja em outra esfera que não a física, estendendo-a, ao mesmo tempo em que sutilmente exponha seu usuário. Facilitando a identificação de gestos, pelo volume do falar, pelo gosto musical, pelo armazenamento da imagem de pessoas que se quer bem. Espelha o usuário porque dá a ele uma liberdade, ainda que limitada, em mediar sua comunicação proteticamente, diferentemente de outros mediadores (TV e rádio não são personalizados, a web ainda é limitada a um espaço fixo).

A personalização do texto, a seleção da foto do papel de parede, a música escolhida como toque para cada ligação, o que se mantém na agenda, a seleção musical ou a rádio $\mathrm{FM}$ escolhida, são modos de representação de mundo do usuário. E nele está retratado não somente desejos e necessidades, mas principalmente suas possibilidades econômicas e culturais, suas ações políticas postas em ato. Escolher atender alguém ou não, comentar algo após desligar determinada ligação indesejada, poder ou não manter os créditos no celular, compreender seus mecanismos e através deles poder reproduzir seus conteúdos. Esta é uma outra faceta do mobile, confrontada com o simbólico. 
Os usos do celular representam também o reconhecimento de onde se está. Por isso existem os ajustes para permanecer conectado (as articulações entre os que têm crédito e os que não têm para que consigam se comunicar), a reivindicação silenciosa que se traduz em falta de uso por falta de créditos se transforma em promoção da operadora. O compartilhamento que não acontece pela falta de bluetooth se dá no DVD.

O jogo que se reproduz com o uso do telefone celular é negociado. Existem vantagens e desvantagens, lucros e perdas em ambos os lados (operadora e usuário). O que transparece nas expressões através do mobile é o espaço de relevância para a formação cultural, dos sentidos, do simbólico. Ele representa o cotidiano, principalmente em seu aspecto familiar, de trabalho, de lazer. As desigualdades se efetivam pelas representações das diferenças nesses ambientes. Quando esse cotidiano é posto em tensão na esfera política, econômica ou cultural, o indivíduo mobiliza um determinado papel social, através do qual posiciona-se criticamente ou passivamente diante dessa tensão.

Os meios de comunicação são mediadores dessas relações ambíguas. Mas o telefone celular é inovador, pois concentra em si as características de todos os outros meios, e ainda apresenta a mobilidade que muitos não têm. $\mathrm{E}$ assim como os outros, representa quem o usa, pelo fato de ser somente um significante. As significações atribuídas aos seus usos dependem do momento da relação que se observa. Desde a produção de conteúdos, passando pela distribuição de aparelhos, pela operação da telefonia, até as etapas de desejo de aquisição e efetivação da compra, e posteriormente seus usos, o telefone celular significa um instrumento de igualdades e desigualdades -- em maior e menor grau de acordo com o momento --, de manipulação, de vigilância, de exploração. Mas também de entretenimento, de segurança, de inclusão. $O$ segredo está em saber quem é o sujeito dessas complexas relações. Se é que ele existe. 


\section{REFERÊNCIAS BIBLIOGRÁFICAS}

ADORNO, Theodor. Televisione e modelli di cultura di massa, 1954, in LIVOLSI, M. Comunicazione e cultura di massa. Hoepli: Milão, 1969.

ALMEIDA, Maria Isabel M. de e Tracy, Kátia Maria de A. Noites nômades: espaço e subjetividade nas culturas jovens contemporâneas. Rio de Janeiro: Rocco, 2003.

BAUMAN, Zygmund. Modernidade líquida. Rio de Janeiro: Jorge Zahar Editores, 2001.

BOURDIEU, Pierre. A distinção: crítica social do julgamento. São Paulo: Edusp; Porto Alegre, RS: Zouk, 2007. . O poder simbólico. Rio de Janeiro: Bertrand Brasil, 2007.

BRIGGS, Asa; Burke, Peter. Uma história social da mídia. Rio de Janeiro: Jorge Zahar Editores, 2004.

CANCLINI, Néstor, Garcia. Diferentes, desiguais e desconectados. Rio de Janeiro: UFRJ, 2005.

. Consumidores e cidadãos. Rio de Janeiro: UFRJ, 1999.

. Culturas híbridas. São Paulo: EDUSP, 1998.

CASTELLS, Manuel. A sociedade em rede. São Paulo: Paz e Terra, 1999.

. The rise of the network society. Oxford: Malden, MA: Blackwell Publishers, 2000.

CERTEAU, Michel de. A invenção do cotidiano. Petrópolis, RJ: Vozes, 2001.

CORRÊA, Diogo. Somos desiguais? a propósito de Jessé Souza e Roberto DaMatta. In: SOUZA, Jessé (org.). A invisibilidade da desigualdade brasileira. Belo Horizonte: UFMG

COSTA LIMA, Luiz. Teoria da cultura de massa. São Paulo: Paz e Terra, 2000.

DAGNINO, Evelina. Anos 90: política e sociedade no Brasil. São Paulo: Brasiliense, 2004.

DAVIS, Mike. Planeta favela. São Paulo: Biotempo, 2006.

DÍAZ, Laura Mota. Instituições do Estado e produção e reprodução da desigualdade na América Latina. Apud CIMADAMORE, Alberto e CATTANI, Antônio David. Produção de pobreza e desigualdade na América Latina. Porto Alegre: Tomo Editorial/Clacso, 2008

EDER, Klaus. A nova política de classe. Bauru, SP: EDUSC, 2002.

ELIAS, Norbert, SCOTSON, John L. Os estabelecidos e os outsiders: sociologia das relações de poder a partir de uma pequena comunidade. Rio de Janeiro: Jorge Zahar, 2000.

FRAZEN, Jonathan. Amor sem pudor. Folha de São Paulo. São Paulo, 16 de novembro de 2008. Caderno Mais, p. 4.

FREITAS, Ronaldo et al. Para que serve a nova geração de celulares. São Paulo: Revista Época, Editora Globo, no. 501, 24 de dezembro de 2007, p. 40, 41.

FLUSSER, Vilém. $O$ mundo codificado: por uma filosofia do design e da comunicação. São Paulo: Cosac Naify, 2007. 
GODOI, Christian. Os sentidos da violência: TV, celular e novas mídias. Santos, SP: Realejo Edições, 2008.

GRIGNON, Claude; PASSERON, Jean-Claude. Lo culto y lo popular: miserabilismo y populismo en sociologia y en literature. Buenos Aires: Nueva Visión, 1991

GRUPPI, Luciano. O conceito de hegemonia em Gramsci. Rio de Janeiro: Graal, 1978.

HALL, Stuat. Da diáspora. Belo Horizonte: UFMG, 2003.

INNERARITY, Daniel. A transformação da política. Lisboa: Teorema, 2002,

JACKS, Nilda. Querência: cultura regional como mediação simbólica. Porto Alegre: UFRGS, 1999.

JOHNSON, Steven. Cultura de interface. Rio de Janeiro: Jorge Zahar, 2001.

LEMOS, André. Cidade e mobilidade: telefones celulares, funções pós-massivas e territórios informacionais. MATRIZes. Revista do Programa de Pós-Graduação em Ciências da Comunicação da Universidade de São Paulo. Ano 1, n. 1 (jul - dez 2007) - São Paulo: ECA/USP, 2007a.

. Comunicação e práticas sociais no espaço urbano: as características dos dispositivos híbridos móveis de conexão multirredes (DHMCM). In: Revista Comunicação, Mídia e Consumo. São Paulo, v. 4, no. 10, p. 24, jul. 2007b.

LYOTARD, Jean-François. A condição pós-moderna. Rio de Janeiro: José Olympio, 2000.

LOPES DE SOUZA, Marcelo. ABC do desenvolvimento urbano: Rio de Janeiro: Bertrand Brasil, 2007.

MAFFESOLI, Michel. Tempo das tribos: o declínio do individualismo nas sociedades de massa. Rio de Janeiro: Forense Universitária, 2000.

. A comunicação sem fim: teoria pós-moderna da comunicação. Apud Martins, Francisco M.; Machado da Silva, Juremir. A genealogia do virtual. Porto Alegre: Sulina, 2004.

MANTOVANI, Camila Maciel C. A. Info-entretenimento na telefonia celular: informação, mobilidade interação social e um novo espaço de fluxos. Belo Horizonte: Escola de Ciência da Informação, UFMG, 2006.

MARCONDES FILHO, Ciro. Martín-Barbero, Canclini, Orozco: os impasses de uma teoria da comunicação latino americana. Revista Famecos. Porto Alegre, n. 35, abril de 2008.

MARCONI, Marina de Andrade, LAKATOS, Eva Maria. Metodologia do trabalho científico. São Paulo: Atlas, 2001

MARTÍN- BARBERO, Jesús. Dos meios às mediações. Rio de Janeiro: UFRJ, 1999.

MERTON, Robert. Sociologia: teoria e estrutura. São Paulo: Mestre Jou.

O celular como bola de cristal. Revista Veja especial tecnologia, São Paulo, ano 41, no. 2078, set. 2008, p.56

RYDLEWSKI, Carlos. 100 milhões de celulares. São Paulo: Revista Veja, Editora Abril, edição 1991, 17 de janeiro de 2007, p. 68, 69. 
RÜDIGER, Francisco. Introdução às teorias da cibercultura. Porto Alegre: Sulina, 2007.

SANTAELLA, Lucia. Culturas e artes do pós-humano: da cultura das mídias à cibercultura. São Paulo: Paulus, 2003.

SAUSSURE, F. Curso de lingüistica geral. In: KRISTEVA, Júlia. História da linguagem. Lisboa: Edições 70, 2003.

SIMMEL, Georg. Questões fundamentais da sociologia. Rio de Janeiro: Jorge Zahar, 2006.

SORJ, Bernardo e MARTUCCELLI, Danilo. O desafio latino-americano: coesão social e democracia. Rio de Janeiro: Civilização Brasileira, 2008.

SOUSA, Mauro Wilton. Recepção mediática e espaço público: novos olhares. São Paulo: Paulinas, 2006. . Sujeito o lado oculto do receptor. São Paulo: EDUSP, 1995.

SOUZA E SILVA, Adriana. Do ciber ao híbrido: tecnologias móveis como interfaces de espaços híbridos. In: ARAÚJO, Denise Correa (org.). Imagem (ir)realidade: comunicação e cibermídia. Porto Alegre: Sulina, 2006.

SOUSA SANTOS, Boaventura. A globalização e as ciências sociais. São Paulo: Cortez, 2002.

SUN, Alex. Projeto da praça: convívio e exclusão no espaço público. São Paulo: Senac, 2008.

TRIVINHO, Eugênio. Dromocracia cibercultural: lógica da vida humana na civilização mediática avançada. São Paulo: Paulus, 2007.

. O mal-estar da teoria: a condição crítica na sociedade tecnológica atual. Rio de Janeiro: Quartet, 2001.

WEBER, Max. Economia e sociedade. Brasília, DF: Editora Universidade de Brasília: São Paulo: Imprensa Oficial do Estado de São Paulo, 1999.

WILIAMS, Raymond. Cultura. Rio de Janeiro: Paz e Terra, 1992

WOLF, Mauro. Teorias da comunicação. Lisboa: Presença Editorial, 1999.

WOLTON, Dominique. É preciso salvar a comunicação. São Paulo: Paulus, 2006. . Internet, e depois? Porto Alegre: Sulina, 2003

http://www.bluetooth.org.

http://www.dodgeball.com

http://www.imity.com

http://www.ipsos.com.br, acessado em 25 de agosto de 2008

http://www.rfidjournal.com

http://www.teleco.com.br. Acessado no dia 23 de setembro de 2008.

http://www.wi-fi.org. 
Lemos, André. Mídia locativa e territórios informacionais, in Carnet de notes, http://www.facom.ufba.br/ciberpesquisa/andrelemos/locativa.pdf, janeiro de 2007 


\section{ANEXOS}

\section{a) Formulários}

\section{A seguir texto explicado aos pesquisadores, e posteriormente o} formulário usado para a pesquisa de campo:

O que se quer observar é a representação do sujeito quando no uso do celular.

O sujeito se representa através da representação que o outro faz dele; da mesma forma em que o outro se representa pelo primeiro sujeito, percebendo-se assim no outro que nele se vê representado.

Imagina-se que a representação de uma identidade vinculada a um local se dá também pela possibilidade de se ver refletido por seus antagonistas (ou pela imagem que eles criam daquilo que não necessariamente se é). Dois espaços de produção de sentido claramente opostos, em uma mesma região, carregam consigo não somente as representações dos modos cotidianos dos seus moradores, como também as formas pelas quais são vistos pelos seus desiguais: O morro e a praia. Um terceiro espaço, o centro, é visto como um ambiente de passagem, no qual todos e qualquer um pode se encontrar e comungar sem sentir-se estranho.

\section{SOBRE A PESQUISA}

Postura do entrevistador:

a) Abordar sempre se apresentado como pesquisador (ECA/USP - Aluno do prof. Christian Godoi - Unimonte/Unisanta)

b) Se necessário mostre sua carteira de estudante

c) Mantenha distanciamento do entrevistado

d) Aceite a rejeição tranquilamente

e) Busque mesclar entrevistados ( 2 homens e três mulheres e vice-versa)

f) Seja simpático, não íntimo

g) Não forçe respostas

Para a realização da pesquisa de campo parte-se da hipótese de que o uso do celular reproduz as diferenças da desigualdade social. Essa reprodução, acredita-se, pode ser percebida mais efetivamente, por exemplo, a partir do local de produção de sentidos vinculado às práticas cotidianas, "lugar de interiorização muda da desigualdade social", aponta Barbero; local que permite a "expressão dos desejos a subversão dos códigos e movimentos de pulsão e de gozo"147, um lugar que se busca ou se freqüenta sem necessidade de alterar bruscamente o papel social, lugar no qual se sente partícipe do ambiente comum. Os dois espaços representativos para este trabalho são a praia (como um centro) e o morro (como um olhar distinto ao do centro).

Esta pesquisa deve ser realizada durante o dia em finais de semana (preferencialmente em um dia útil da semana e posteriormente em um sábado à tarde ou domingo) para que os

${ }^{147}$ Martín- Barbero, Jesús. Dos meios às mediações. Rio de Janeiro: UFRJ, 1999, p. 290 
habitantes desses dois lugares estejam desprovidos de laços de compromissos, livres para que suas práticas culturais se dêem mais espontaneamente.

Têm-se como variáveis e seus indicadores operacionais:

- sociabilidade: usos do celular para construção ou reafirmação de relacionamentos, reforço de laços afetivos, bem como para trabalho ou relações vinculadas a atividades profissionais;

- condição econômica: possibilidade econômica de acesso ao conteúdo através de aparelhos pós-pagos ou pré-pagos;

- prestígio social: uso do aparelho (marca, modelo, instrumentos hibridados) como representação do lugar social que ocupa;

- informação: troca de informação ou aquisição de conteúdo para uso cotidiano;

- entretenimento: instrumento para passatempo;

- relação com o espaço local: usos do celular para interagir com o espaço físico ou com outras máquinas disponibilizadas;

- tecnologia: atualização tecnológica constante para aproveitar efetivamente os potenciais do aparelho.

\section{Indicadores dos entrevistados:}

\section{1- NOME:}

\section{2- IDADE:}

3- SEXO:

\section{4- RESIDÊNCIA:}

\section{5- PROFISSÃO:}

\section{6- RENDA INDIVIDUAL:}

a) () até dois salários mínimos

b) () entre dois e quatro salários mínimos

c) ( ) entre quatro e dez salários mínimos

d) () acima de dez salários

\section{7- RENDA FAMILIAR:}

a) () até dois salários mínimos

b) ( ) entre dois e quatro salários mínimos

c) ( ) entre quatro e dez salários mínimos

d) () acima de dez salários

\section{8- ESTADO CIVIL:}

a) () solteiro

b) () casado

c) () separado

d) () outros

\section{9- VEÍ́CULO}

\section{a) () SIM - CARRO}

MARCA

ANO:

b) ( ) SIM - MOTO

MARCA ANO: 
C) ( ) NÃO

10- TELEFONE CELULAR:

a) ( ) PRÉ- PAGO

b) ( ) PÓS-PAGO

11- HÁ QUANTO TEMPO POSSUI ESTE APARELHO:

a) ( )menos de 1 ano

b) ( )mais de um ano

12- QUANDO EFETUA A TROCA DO EQUIPAMENTO?

a) ( ) a cada ano

b) () quando surgem novidades

c) ( ) quando perde o aparelho

d) () nunca trocou

13- OPERADORA:

a) () Claro

b) () TIM

c) () Vivo

d) () Nextel

d) () outra

14- SERVIÇOS DISPONIBILIZADOS PELA OPERADORA USADOS POR VOCÊ:

a) () Ringtones

b) () Wallpaper

c) () GPS

d) ( )Músicas

e) () outros

15- MARCA DO APARELHO:

a) () Motorola

b) ( ) Sony-Erickson

c) () Siemens

d) ( ) Nokia

e) ( ) LG

f) () não sabe

g) () outras

16- EQUIPAMENTOS HIBRIDADOS MAIS UTILIZADOS (numerar por prioridade):

a) ( ) Câmera fotográfica

b) ( ) filmadora

c) () Bluetooth

d) () MP3 player

e) ( ) rádio FM

f) ( ) outro

g) () nenhum

17- LUGARES EM QUE USA O CELULAR COM FREQÜÊNCIA:

a) ( ) Casa 
b) () Rua

c) ( ) Trabalho/interno

d) ( ) Balada 
Questões:

18- PARA QUE USA O CELULAR NORMALMENTE?

19- COM QUEM FALA NA MAIOR PARTE DO TEMPO DE USO?

20- COMPARTILHA CONTEÚDOS (MENSAGENS, MÚSICAS, PAPÉIS DE PAREDE ETC)? COM QUEM?

21- O QUE FAZ COM OS CONTEÚDOS (FOTOS, MÚSICAS, VIDEOS) ARMAZENADOS NO APARELHO?

22- ESTÁ SATISFEITO COM O SEU APARELHO?GOSTA DO MODELO E DOS APETRECHOS?

23- O QUE FARIA SE PERDESSE O CELULAR HOJE? POR QUÊ?

24- POR QUE O APARELHO É IMPORTANTE NA SUA VIDA?

Para pré-pagos:

25- COM QUANTOS REAIS EM CRÉDITO ABASTECE MENSALMENTE?

26- QUANTO TEMPO DURAM OS CRÉDITOS?

27- QUANDO ACABAM OS CRÉDITOS, COMO USA O APARELHO? 


\section{b) Gabaritos}

\section{GABARITO PARA TABULAÇÃO}

1. Nome/ordem

2. Idade: 1) 14 a 18 - 2) 19 a 24 - 3) 25 a 30 - 4) 31 a 35 - 5) acima de 35 anos

3. 1) homem - 2) mulher

4. 1) praia/praia - 2) praia/bairro - 3) morro

5. a) estudante; b) vendedor; c) comerciária; d) motorista; e) balconista; f) comerciante; g) taxista; h) vigia; i) dona de casa; j) auxiliar de limpeza; k) jornaleiro; I) consultor de mídia; m) instrutor da polícia civil; n) mecânico; o) pintor; p) ascensorista; q) despachante aduaneiro; r) funileiro; s) secretário; t) empresário; u) advogado; v) engenheiro; w) aposentado; x) publicitário; y) desempregado; z) administrador

6. RENDA INDIVIDUAL: a) até dois salários mínimos; b) entre dois e quatro salários mínimos; c) entre quatro e dez salários mínimos; d)acima de dez salários

7. RENDA FAMILIAR: a) até dois salários mínimos; b) entre dois e quatro salários mínimos; c) entre quatro e dez salários mínimos; d) acima de dez salários

8. ESTADO CIVIL: a) Solteiro; b) Casado; c) Separado

9. veículo: 1: Volkswagen a) Gol; b) Cross Fox; c) Passat - 2: Fiat a) Uno; b) Siena; c) não declarou - 3: Ford a) Fiesta Montana - 4: Renault a) Clio; b) Scenic - 5: Citroen a) Picasso - 6: Chevrolet a) Meriva; b) Corsa - 7: Yamaha a) Fazer - 8: Honda a) CG; b) Strada; c) não declarada - 9: Suzuki a) Burgman 125 - 10: não declarou o veículo

10. TELEFONE CELULAR: a) PRÉ- PAGO; b) PÓS-PAGO

11. HÁ QUANTO TEMPO POSSUI ESTE APARELHO: a) menos de 1 ano; b) mais de um ano

12. QUANDO EFETUA A TROCA DO EQUIPAMENTO?; a) a cada ano; b) quando surgem novidades; c) quando perde o aparelho; d) nunca trocou

13. OPERADORA: a) Claro; b) TIM; c) Vivo; d) outra 
14. SERVIÇOS DISPONIBILIZADOS UTILIZADOS POR VOCÊ: a) Ringtones; b) Wallpaper; c) GPS; d) Músicas; e) Web; f) outros

15. MARCA DO APARELHO: a) Motorola; b) Sony-Erickson; c) Siemens; d) Nokia ; e) não sabe; f) outra

16. EQUIPAMENTOS HIBRIDADOS MAIS UTILIZADOS (numerar por prioridade): a) Câmera fotográfica; b) filmadora; c) GPS; d) MP3 player; e) rádio FM ; f) nenhum

17. LUGARES EM QUE USA O CELULAR COM FREQÜÊNCIA: a) Casa; b) Rua; c) Trabalho/interno; d) Balada

18. PARA QUE USA O CELULAR NORMALMENTE? a)mensagens;b)conversa;c)tocar música;d)falar com a família;e)para marcar noitada;f)vigilância do filho;g)fazer ligação;h)falar com creche;i)trabalho;j)procurar emprego;k)emergência; I)ligar para casa;m)falar com amigo;n)para receber e fazer ligações;o)atender clientes ou fregueses;p)tudo;q)contatos;r)câmera fotográfica;s)recebe ligação de mãe e amigos;t)parentes;u)em geral);v)para ser encontrado

19. COM QUEM FALA NA MAIOR PARTE DO TEMPO DE USO? a)namorada;b)família;c)amigos;d)marido;e)pai;f)mãe;g)filhos;h)casa; i)esposa;j)clientes;k)pesoal;I)chefe;m)serviço;n)particular;o)investigadores de polícia

20. TROCA CONTEÚdOS (SMS OU MÚSICAS, PAPÉIS DE PAREDE ETC) CONSTANTEMENTE? COM QUEM? a)sim; b)não;c)música;d)papéis de parede;e)com amigo;f)SMS;g)Bluetooth;h)com o marido;i)não respondeu;j)fotos

21. O QUE FAZ COM OS CONTEÚDOS ARMAZENADOS NO APARELHO (FOTOS, MÚSICAS, VIDEOS)? a)usa para si;b)passa foto para Orkut;c)fica no aparelho;d)apaga;e)guarda;f)passa para o PC;g)usa toques;h)não respondeu;i)não tem dispositivos de armazenamento;j)nada;k)guarda foto;I)nada;m)escuta; $n)$ compartilha;o)imprime

22. ESTÁ SATISFEITO COM O SEU APARELHO?GOSTA DO MODELO E DOS APETRECHOS? a)sim;b)não envia nem recebe;c)gostaria de mudar;d)satisfeita com o que tem;e)podia ser melhor;f)não;g)se acostumou;h)por enquanto;i)nunca deu problema

23. COM QUANTOS REAIS EM CRÉDITO ABASTECE MENSALMENTE? a)10 a 15 reais;b)16 a 20 reais;c)21 a 25 reais;d)26 a 40 reais;e)41 a 50 reais;f)51 a 100 reais;g)200 reais

24. QUANTO TEMPO DURAM OS CRÉDITOS? a)até uma semana;b)de uma a duas semanas;c)entre 15 e 20 dias;d)até um mês;e)mais de um mês;f)um ano 
25. QUANDO ACABAM OS CRÉDITOS, COMO USA O APARELHO? a)recarrega quando dá;b)liga a cobrar;c)recebe;d)só manda torpedo;e)espera para colocar créditos;f)fotos e músicas;g)sempre mantém com crédito;h)ouve música 


\section{c)Tabelas de resultados em números de entrevistados.}

Referências de profissões

a) Desempregado; b) vendas; c) comerciário; d) autônomo;

e) estudante; f) telecomunicação; g) padeiro; $h$ ) administrativo;

i) funerário; j) profissional liberal; I) porteiro; $m$ ) serviços técnicos;

n) empresário; o) funcionário público.

Referências de rendimento familiar
a) até dois salários mínimos
b) entre dois e quatro salários mínimos
c) entre quatro e dez salários mínimos
d) acima de dez salários
e) não declarou
f) não tem ganho

Tabela indicativa de local, renda e profissão

\begin{tabular}{|l|l|l|l|l|l|l|}
\hline Local & Morro & & & & & \\
\hline & Renda & & & & & \\
\hline Profissão & A & B & C & D & E & F \\
\hline A & 3 & & & & & \\
\hline B & & 1 & 2 & & & \\
\hline C & & & & & & 1 \\
\hline D & 1 & 3 & 1 & 1 & & \\
\hline E & & 4 & & & & \\
\hline F & & & & 1 & & \\
\hline G & 1 & & & & & \\
\hline H & 1 & 2 & & & & \\
\hline I & 1 & & & & & \\
\hline J & & & & & & 1 \\
\hline K & & & & & & \\
\hline L & & 1 & & & & \\
\hline M & 1 & 1 & & & & \\
\hline Total & 8 & 12 & 3 & 2 & & 2 \\
\hline 27 & & & & & & \\
\hline
\end{tabular}


Tabela indicativa de local, renda e profissão

\begin{tabular}{|c|c|c|c|c|c|c|}
\hline Local & Praia & & & & & \\
\hline & Renda & & & & & \\
\hline Profissão & A & $B$ & C & $D$ & $E$ & $\mathrm{~F}$ \\
\hline \multicolumn{7}{|l|}{ A } \\
\hline \multicolumn{7}{|l|}{ B } \\
\hline C & & & & & & 1 \\
\hline D & 1 & 1 & & & & 2 \\
\hline$E$ & & 2 & 2 & 1 & & \\
\hline \multicolumn{7}{|l|}{$F$} \\
\hline \multicolumn{7}{|l|}{ G } \\
\hline $\mathrm{H}$ & & & 1 & 1 & & \\
\hline \multicolumn{7}{|l|}{ I } \\
\hline J & & 1 & 1 & 6 & & \\
\hline \multicolumn{7}{|l|}{$\mathrm{K}$} \\
\hline \multicolumn{7}{|l|}{$\mathrm{L}$} \\
\hline $\mathrm{M}$ & & 2 & & & & 1 \\
\hline $\mathrm{N}$ & & 1 & & 1 & & \\
\hline $\mathrm{O}$ & & & 1 & & & \\
\hline Total & 1 & 7 & 5 & 9 & 0 & 4 \\
\hline 26 & & & & & & \\
\hline
\end{tabular}

Tabela indicativa de local, renda e profissão

\begin{tabular}{|l|l|l|l|l|l|l|}
\hline Local & Centro & & & & & \\
\hline & Renda & & & & & \\
\hline Profissão & A & B & C & D & E & F \\
\hline A & & & & & & \\
\hline B & & & 1 & & & \\
\hline C & & & & & 2 & \\
\hline D & & 1 & 1 & & 1 & \\
\hline E & & & & & 1 & \\
\hline F & & & & & & \\
\hline G & & & & & & \\
\hline H & & 2 & & 2 & & \\
\hline I & & & & & & \\
\hline J & & 1 & & 1 & & \\
\hline K & & & & & & \\
\hline L & & & & & & \\
\hline M & & & & & & 1 \\
\hline N & & & & & & \\
\hline O & & & & & & 1 \\
\hline Total & 0 & 4 & 2 & 3 & 4 & 2 \\
\hline 15 & & & & & & \\
\hline
\end{tabular}


Tabela indicativa de local, renda e veículo

\begin{tabular}{|c|c|c|c|c|c|c|c|c|}
\hline \multicolumn{9}{|l|}{ Morro } \\
\hline Renda & A & $B$ & C & D & $E$ & Ano & a-até 90 & b- $91 / 00$ \\
\hline Veículo/a & & & & & & B & c-01/05 & $d-06 / 09$ \\
\hline 1-VW & & & & 1 & & & & \\
\hline \multicolumn{9}{|l|}{ 2- Ford } \\
\hline 3- GM & & 1 & & & 1 & $\mathrm{c} / \mathrm{c}$ & & \\
\hline 4-Fiat & & 1 & & & & $B$ & & \\
\hline \multicolumn{9}{|l|}{$\begin{array}{l}\text { 5- } \\
\text { Peugeot }\end{array}$} \\
\hline 6-Mitsub & & & & 1 & & D & & \\
\hline \multicolumn{9}{|l|}{ 7-Citroen } \\
\hline \multicolumn{9}{|l|}{ 8-Honda } \\
\hline 9-Outros & & 1 & & & & A & & \\
\hline \multirow{2}{*}{\multicolumn{9}{|c|}{ Veículo/b }} \\
\hline & & & & & & & & \\
\hline 1-Honda & 1 & 2 & & & & $\mathrm{c} / \mathrm{c} / \mathrm{d} / \mathrm{d}$ & & \\
\hline \multicolumn{9}{|c|}{\begin{tabular}{|l|l|}
$2-$ \\
Yamaha
\end{tabular}} \\
\hline \multicolumn{9}{|l|}{ 3-Suzuki } \\
\hline \multicolumn{9}{|l|}{ 4-Outras } \\
\hline & & & & & & & & \\
\hline $\begin{array}{l}\text { Não } \\
\text { tem/c }\end{array}$ & 7 & 8 & 3 & & & & & \\
\hline
\end{tabular}

Tabela indicativa de local, renda e veículo

\begin{tabular}{|l|l|l|l|l|l|l|}
\hline Praia & & & & & & \\
\hline Renda & A & B & C & D & E & Ano \\
\hline Veículo/a & & & & & & \\
\hline 1 & & 1 & 2 & & 1 & $\mathrm{~b} / \mathrm{b} / \mathrm{d} / \mathrm{d}$ \\
\hline 2 & & & & & & \\
\hline 3 & & & & 1 & 1 & $\mathrm{C} / \mathrm{d}$ \\
\hline 4 & & & & & & \\
\hline 5 & & & & & & \\
\hline 6 & & & & & & \\
\hline 7 & & & & 1 & & C \\
\hline 8 & & & & 3 & & $\mathrm{a} / \mathrm{d} / \mathrm{d}$ \\
\hline 9 & & 1 & 1 & 2 & 1 & $\mathrm{~b} / \mathrm{c} / \mathrm{d} / \mathrm{d}$ \\
\hline & & & & & & \\
\hline Veículo/b & & & & & & \\
\hline 1 & 1 & 1 & & & & $\mathrm{~b} / \mathrm{d}$ \\
\hline 2 & & & & & & \\
\hline 3 & & & & & & \\
\hline 4 & & & & & & \\
\hline & & & & & & \\
\hline não tem & & 3 & 3 & 2 & 1 & \\
\hline
\end{tabular}


Tabela indicativa de local, renda e veículo

\begin{tabular}{|c|c|c|c|c|c|c|}
\hline Centro & & & & & & \\
\hline Renda & A & $B$ & C & $\mathrm{D}$ & $E$ & Ano \\
\hline \multicolumn{7}{|l|}{ Veículo/a } \\
\hline \multicolumn{7}{|l|}{1} \\
\hline 2 & & & & 1 & & D \\
\hline 3 & & & 1 & & 1 & $\mathrm{c} / \mathrm{d}$ \\
\hline 4 & & & & 1 & & B \\
\hline 5 & & & & & 1 & C \\
\hline \multicolumn{7}{|l|}{6} \\
\hline \multicolumn{7}{|l|}{7} \\
\hline \multicolumn{7}{|l|}{8} \\
\hline \multicolumn{7}{|l|}{9} \\
\hline & & & & & & \\
\hline \multicolumn{7}{|c|}{ Veículo/b } \\
\hline 1 & & 2 & 1 & & & $\mathrm{c} / \mathrm{d} / \mathrm{d}$ \\
\hline \multicolumn{7}{|l|}{2} \\
\hline \multicolumn{7}{|l|}{3} \\
\hline \multicolumn{7}{|l|}{4} \\
\hline & & & & & & \\
\hline & & & & & & \\
\hline não tem & & 1 & 1 & 1 & 4 & \\
\hline
\end{tabular}

Tabela indicativa de local, renda e plano do celular

\begin{tabular}{|l|l|l|l|l|l|l|}
\hline Local & Morro & & Praia & & Centro & \\
\hline renda/fml & Prépago & Póspago & prépago & Póspago & Prépago & póspago \\
\hline a- 2 sm & 7 & 1 & & 1 & & \\
\hline b- $2 / 4$ & 10 & 2 & 5 & 2 & 3 & \\
\hline c- $5 / 10$ & 2 & 1 & 3 & 2 & 1 & 2 \\
\hline d- +10 & 2 & & 4 & 5 & 3 & \\
\hline e- n.d.a. & 2 & & 3 & 1 & 5 & 1 \\
\hline Total & 23 & 4 & 15 & 11 & 12 & 3 \\
\hline 27 & & & & & & \\
\hline 26 & & & & & & \\
\hline 15 & & & & & & \\
\hline
\end{tabular}

Gabarito para renda

a) até dois salários mínimos

b) entre dois e quatro salários mínimos

c) entre quatro e dez salários mínimos

d) acima de dez salários

e) não declarou

f) não tem ganho 
Tabela com local, renda, operadora, tempo de aquisição

Gabarito para operadoras:

a) Claro b) Tim c) Vivo d) Nexte e) Outras;

\begin{tabular}{|c|c|c|c|c|c|c|c|}
\hline Morro & $\begin{array}{l}\text { tempo de } \\
\text { aquisição }\end{array}$ & & operadora & & & & \\
\hline Renda & até 1 ano & $\begin{array}{l}1 \text { ano } \\
\text { out }\end{array}$ & A & B & C & D & $\mathrm{E}$ \\
\hline $\mathrm{C}$ & 1 & & & & & 1 & \\
\hline$A$ & & 1 & & 1 & & & \\
\hline A & 1 & & 1 & & & & \\
\hline$A$ & & 1 & & 1 & & & \\
\hline$D$ & & 1 & & & 1 & & \\
\hline$A$ & 1 & & & & 1 & & \\
\hline B & & 1 & 1 & & & & \\
\hline$B$ & & 1 & & 1 & & & \\
\hline$B$ & 1 & & & & 1 & & \\
\hline$B$ & & 1 & & & 1 & & \\
\hline$A$ & 1 & & 1 & & & & \\
\hline C & & 1 & & & 1 & & \\
\hline$A$ & 1 & & & & 1 & & \\
\hline$B$ & & 1 & 1 & & 1 & & \\
\hline B & 1 & & & & 1 & & \\
\hline C & & 1 & & & 1 & & \\
\hline$E$ & & 1 & 1 & & & \begin{tabular}{|l|}
1 \\
\end{tabular} & \\
\hline$D$ & & 1 & & & 1 & & \\
\hline A & & 1 & 1 & & & & \\
\hline $\mathrm{E}$ & 1 & & 1 & & & & \\
\hline$B$ & 1 & & & & 1 & & \\
\hline B & & 1 & 1 & & & & \\
\hline B & & 1 & 1 & & & & \\
\hline A & & 1 & & & 1 & & \\
\hline$B$ & 1 & & & & 1 & & \\
\hline B & 1 & & 1 & & & & \\
\hline B & & 1 & & & 1 & & \\
\hline Total & 11 & 16 & 10 & 3 & 14 & 2 & 0 \\
\hline 27 & & & & & & & \\
\hline
\end{tabular}


Tabela com local, renda, híbridos

\begin{tabular}{|c|c|c|c|c|c|c|c|}
\hline Morro & Híbridos & & & & & & \\
\hline Renda & A & $B$ & $C$ & $D$ & $E$ & $F$ & G \\
\hline$C$ & & & & & & & 1 \\
\hline A & & & & & & & 1 \\
\hline A & & & & & 1 & & \\
\hline A & & & 1 & & 1 & & \\
\hline $\mathrm{D}$ & & & & & & 1 & \\
\hline A & 1 & 1 & & & 1 & & \\
\hline$B$ & & & & & 1 & & \\
\hline$B$ & & & & & & & 1 \\
\hline$B$ & 1 & & 1 & 1 & & & \\
\hline B & & & & & & & 1 \\
\hline A & 1 & & & 1 & 1 & & \\
\hline C & & & & & & & 1 \\
\hline A & & 1 & 1 & & 1 & & \\
\hline B & 1 & & & & & & \\
\hline$B$ & 1 & & 1 & 1 & & & \\
\hline $\mathrm{C}$ & 1 & & & & & & \\
\hline $\mathrm{E}$ & 1 & & & & & & \\
\hline $\mathrm{D}$ & & & & & & & 1 \\
\hline A & 1 & & 1 & & & & \\
\hline$E$ & 1 & & 1 & 1 & 1 & & \\
\hline B & & & 1 & & 1 & & \\
\hline$B$ & 1 & & & & & & \\
\hline$B$ & & & & & & & 1 \\
\hline$A$ & & & & & & & 1 \\
\hline B & & & & & & & 1 \\
\hline$B$ & & & & 1 & & & \\
\hline \multirow[t]{2}{*}{$B$} & 1 & & 1 & 1 & 1 & & \\
\hline & 11 & 2 & 8 & 6 & 9 & 1 & 9 \\
\hline
\end{tabular}

Gabarito para híbridos

a) Câmera fotográfica

b) filmadora

c) Bluetooth

d) MP3 player

e) rádio FM

f) outro

g) nenhum 
Tabela com local, renda, operadora, tempo de aquisição

\begin{tabular}{|c|c|c|c|c|c|c|c|}
\hline Praia & \begin{tabular}{|l|} 
tempo de \\
aquisição
\end{tabular} & & Operadora & & & & \\
\hline Renda & 1ano & $\begin{array}{l}\text { mais de } \\
1 \text { ano }\end{array}$ & A & B & C & D & $E$ \\
\hline C & 1 & & & 1 & & & \\
\hline $\mathrm{D}$ & & 1 & & & 1 & & \\
\hline$A$ & & & & & 1 & & \\
\hline B & 1 & 1 & & & 1 & & \\
\hline$B$ & & 1 & & 1 & & & \\
\hline B & 1 & & 1 & & & & \\
\hline D & & 1 & 1 & & & & \\
\hline$B$ & & 1 & & 1 & & 1 & \\
\hline $\mathrm{D}$ & & 1 & 1 & & & & \\
\hline $\mathrm{E}$ & 1 & & & & 1 & & \\
\hline $\mathrm{F}$ & 1 & & 1 & & & & \\
\hline$B$ & & 1 & & 1 & & & \\
\hline C & & 1 & & & 1 & & \\
\hline C & & 1 & 1 & & & & \\
\hline D & 1 & & & 1 & & & \\
\hline $\mathrm{D}$ & & 1 & & 1 & & & \\
\hline D & & 1 & & 1 & & & \\
\hline$B$ & & 1 & & 1 & & & \\
\hline $\mathrm{F}$ & & 1 & & & 1 & & \\
\hline $\mathrm{F}$ & & 1 & & 1 & & & \\
\hline C & & 1 & & & 1 & & \\
\hline B & & 1 & & 1 & & & \\
\hline C & 1 & & & 1 & & & \\
\hline D & & 1 & & 1 & & & \\
\hline $\mathrm{D}$ & & 1 & 1 & & & & \\
\hline D & & 1 & & 1 & & & \\
\hline Total & 7 & 19 & 6 & 13 & 7 & 1 & 0 \\
\hline 26 & & & & & & & \\
\hline
\end{tabular}


Tabela com local, renda, híbridos

\begin{tabular}{|c|c|c|c|c|c|c|c|}
\hline $\begin{array}{l}\text { Praia } \\
\text { híbridos } \\
\end{array}$ & & & & & & & \\
\hline Renda & $\mathrm{A}$ & $\mathrm{B}$ & C & $D$ & $E$ & $\mathrm{~F}$ & G \\
\hline C & 1 & & 1 & 1 & & & \\
\hline$D$ & 1 & & & 1 & & & \\
\hline A & 1 & 1 & 1 & 1 & 1 & & \\
\hline B & 1 & 1 & 1 & 1 & 1 & & \\
\hline$B$ & 1 & 1 & & 1 & 1 & & \\
\hline B & 1 & 1 & 1 & 1 & 1 & & \\
\hline D & 1 & & & 1 & & & \\
\hline$B$ & 1 & 1 & 1 & 1 & & & \\
\hline$D$ & 1 & 1 & & & & & \\
\hline$E$ & & & & 1 & & 1 & \\
\hline $\mathrm{F}$ & & & 1 & & 1 & & \\
\hline $\mathrm{B}$ & & & & & & & 1web \\
\hline C & & & & 1 & 1 & 1web & \\
\hline C & 1 & & 1 & 1 & & & \\
\hline$D$ & 1 & 1 & & 1 & & & \\
\hline$D$ & & & & & & 1 & \\
\hline$D$ & & & & & & & 1 \\
\hline$B$ & & & & & & & 1 \\
\hline $\mathrm{F}$ & 1 & 1 & 1 & 1 & 1 & & \\
\hline $\mathrm{F}$ & 1 & 1 & 1 & 1 & 1 & & \\
\hline C & 1 & 1 & 1 & 1 & 1 & & \\
\hline$B$ & & & & & & & 1 \\
\hline C & 1 & 1 & 1 & 1 & 1 & & \\
\hline D & & & & & & & 1 \\
\hline$D$ & 1 & & & & & & \\
\hline D & 1 & & & & & & \\
\hline \multirow[t]{2}{*}{ Total } & 17 & 11 & 11 & 16 & 10 & 3 & 5 \\
\hline & & & & & & 1 web & 1 web \\
\hline
\end{tabular}


Tabela com local, renda, operadora, tempo de aquisição

\begin{tabular}{|l|l|l|l|l|l|l|l|}
\hline Centro & $\begin{array}{l}\text { tempo de } \\
\text { aquisição }\end{array}$ & mais de & Operadora & & & & \\
\hline Renda & 1ano & $\begin{array}{l}\text { 1ano } \\
\text { 1ano }\end{array}$ & A & B & C & D & E \\
\hline E & & 1 & & & 1 & & \\
\hline D & 1 & & 1 & & & & \\
\hline D & & & 1 & & & & \\
\hline B & 1 & & 1 & & & 1 & \\
\hline C & 1 & & & & & 1 & \\
\hline B & 1 & & & & 1 & & \\
\hline D & 1 & & 1 & & & & \\
\hline C & 1 & & & & 1 & & \\
\hline F & & 1 & & 1 & & & \\
\hline E & & 1 & & 1 & & & \\
\hline C & 1 & & & & & 1 & \\
\hline E & 1 & & & 1 & & & \\
\hline E & 1 & & 1 & & & & \\
\hline B & & 1 & 1 & & 3 & 3 & 0 \\
\hline Total & 10 & 5 & 7 & 3 & 3 & & \\
\hline 15 & & & & & & & \\
\hline
\end{tabular}

Tabela com local, renda, híbridos

\begin{tabular}{|c|c|c|c|c|c|c|c|}
\hline Centro & Hibridos & & & & & & \\
\hline Renda & A & B & C & D & $\mathrm{E}$ & $\mathrm{F}$ & 9 \\
\hline $\mathrm{F}$ & & & & 1 & 1 & & \\
\hline $\mathrm{E}$ & & & & & 1 & & \\
\hline D & 1 & 1 & 1 & 1 & 1 & & \\
\hline $\mathrm{D}$ & & & & & & 1 & \\
\hline$B$ & & & & & & & 1 \\
\hline C & & & & & & & 1 \\
\hline$B$ & & & & & 1 & & \\
\hline $\mathrm{D}$ & & & & & & & 1 \\
\hline C & 1 & 1 & & 1 & 1 & & \\
\hline $\mathrm{F}$ & 1 & & & & & & \\
\hline $\mathrm{E}$ & & & & & & & 1 \\
\hline C & & & & & & & 1 \\
\hline $\mathrm{E}$ & & & & & & & 1 \\
\hline $\mathrm{E}$ & 1 & & & & & & \\
\hline$B$ & & & & & & & 1 \\
\hline Total & 4 & 2 & 1 & 3 & 5 & 1 & 7 \\
\hline
\end{tabular}


Tabela Geral, locais, operadora, híbridos, tempo de aquisição

\begin{tabular}{|c|c|c|c|c|}
\hline Morro & tmp d aq & & operadora & híbridos \\
\hline Renda & $\begin{array}{l}\text { a/menos } \\
\text { 1ano }\end{array}$ & $\mathrm{b} / \mathrm{mais} 1$ & a-10 & $a-11$ \\
\hline $8^{a}$ & 11 & 16 & $b-3$ & $b-2$ \\
\hline $12 b$ & & & $c-14$ & c-8 \\
\hline $3 c$ & & & $d-2$ & $d-6$ \\
\hline $2 d$ & & & $e-0$ & e-9 \\
\hline \multirow[t]{2}{*}{$2 e$} & & & & $f-1$ \\
\hline & & & & $g-9$ \\
\hline Praia & & & operadora & Híbridos \\
\hline $1^{a}$ & 7 & 19 & $a-6$ & a-17 \\
\hline $7 b$ & & & $b-13$ & $b-11$ \\
\hline $5 c$ & & & c-7 & $c-11$ \\
\hline $9 d$ & & & $d-1$ & $d-16$ \\
\hline $1 \mathrm{e}$ & & & $e-0$ & e-10 \\
\hline \multirow[t]{2}{*}{$3 f$} & & & & $f-3$ \\
\hline & & & & $g-5$ \\
\hline Centro & & & operadora & Híbridos \\
\hline $0 a$ & 10 & 5 & $a-7$ & $a-4$ \\
\hline $1 b$ & & & $b-3$ & $b-2$ \\
\hline $3 c$ & & & $c-3$ & $c-1$ \\
\hline $3 d$ & & & $d-3$ & $d-3$ \\
\hline $4 \mathrm{e}$ & & & $e-0$ & $e-5$ \\
\hline \multirow[t]{2}{*}{$2 f$} & & & & $f-1$ \\
\hline & & & & $g-7$ \\
\hline total: & 28 & 40 & operadora & Híbridos \\
\hline 9-a & & & a-23 & a-32 \\
\hline $20-b$ & & & $b-19$ & $b-15$ \\
\hline $11-c$ & & & $c-27$ & $c-20$ \\
\hline 14-d & & & $d-6$ & $d-18$ \\
\hline $7-e$ & & & $\mathrm{e}-0$ & e-24 \\
\hline \multirow[t]{2}{*}{$5-f$} & & & & $f-5$ \\
\hline & & & & g-19 \\
\hline
\end{tabular}


Tabelas com local, renda, usos

\section{Gabarito}

a) Casa; b)rua; c) trabalho; d) balada

\begin{tabular}{|c|c|c|c|c|}
\hline & Morro & & & \\
\hline & Usos & & & \\
\hline Renda & $A$ & $B$ & C & $\mathrm{D}$ \\
\hline $\mathrm{C}$ & 1 & 1 & 1 & 1 \\
\hline$A$ & 1 & 1 & 1 & 1 \\
\hline$A$ & 1 & 1 & 1 & 1 \\
\hline A & 1 & 1 & 1 & 1 \\
\hline$D$ & & 1 & & \\
\hline$A$ & & & 1 & \\
\hline$B$ & & 1 & & \\
\hline$B$ & 1 & & & \\
\hline \multicolumn{5}{|l|}{$B$} \\
\hline$B$ & 1 & & & 1 \\
\hline A & & & 1 & \\
\hline $\mathrm{C}$ & & 1 & & \\
\hline$A$ & & 1 & & \\
\hline$B$ & & & 1 & \\
\hline$B$ & & 1 & & \\
\hline $\mathrm{C}$ & & 1 & 1 & \\
\hline$E$ & & 1 & & \\
\hline$D$ & & 1 & & \\
\hline A & 1 & 1 & & 1 \\
\hline$E$ & & & 1 & \\
\hline$B$ & & & 1 & \\
\hline$B$ & 1 & & & \\
\hline$B$ & & 1 & & \\
\hline A & & 1 & & \\
\hline$B$ & 1 & 1 & 1 & 1 \\
\hline$B$ & & 1 & & \\
\hline B & 1 & 1 & & \\
\hline Total & 10 & 18 & 11 & 7 \\
\hline 27 & & & & \\
\hline
\end{tabular}




\begin{tabular}{|c|c|c|c|c|}
\hline & Praia & & & \\
\hline & Usos & & & \\
\hline Renda & A & $B$ & $C$ & $d$ \\
\hline C & & 1 & & \\
\hline$D$ & 1 & 1 & 1 & \\
\hline A & 1 & & 1 & \\
\hline$B$ & 1 & 1 & & \\
\hline$B$ & 1 & & & \\
\hline$B$ & & 1 & & \\
\hline D & & 1 & 1 & \\
\hline$B$ & & 1 & 1 & \\
\hline$D$ & & 1 & & \\
\hline$E$ & 1 & 1 & 1 & 1 \\
\hline$F$ & & 1 & & \\
\hline$B$ & 1 & & & \\
\hline$C$ & & 1 & 1 & 1 \\
\hline $\mathrm{C}$ & 1 & 1 & 1 & 1 \\
\hline D & & 1 & & \\
\hline D & 1 & & 1 & \\
\hline D & & & 1 & \\
\hline$B$ & & & 1 & \\
\hline $\mathrm{F}$ & 1 & 1 & 1 & 1 \\
\hline $\mathrm{F}$ & & 1 & 1 & \\
\hline $\mathrm{C}$ & & 1 & & 1 \\
\hline$B$ & & 1 & & \\
\hline C & & 1 & & \\
\hline D & & 1 & & \\
\hline$D$ & 1 & 1 & 1 & 1 \\
\hline D & & & 1 & \\
\hline Total & 10 & 19 & 14 & 6 \\
\hline 26 & & & & \\
\hline
\end{tabular}


Tabela com local, renda, usos

\begin{tabular}{|l|l|l|l|l|}
\hline & Centro & & & \\
\hline & Usos & & & \\
\hline Renda & A & B & C & D \\
\hline E & & & 1 & \\
\hline E & & 1 & & \\
\hline D & & 1 & & \\
\hline D & & 1 & & \\
\hline B & 1 & 1 & 1 & 1 \\
\hline C & & & 1 & \\
\hline B & & 1 & & \\
\hline D & & & 1 & \\
\hline C & & 1 & & \\
\hline E & & 1 & & \\
\hline E & & 1 & & \\
\hline C & & & 1 & \\
\hline E & & 1 & & \\
\hline E & 1 & & & \\
\hline B & & 1 & & \\
\hline Total & & & & \\
\hline 15 & 2 & 10 & 5 & 1 \\
\hline
\end{tabular}


Tabelas com local, renda, e situação de uso

Gabarito para usos:

a) Trabalho b) Família c) Namoro d) Balada e) Amigos f) Emergência g) Falar h) Viagem i) todas

\begin{tabular}{|l|l|l|l|l|l|l|l|}
\hline Morro & & & & & & \\
\hline Renda & A & B & C & D & E & & Total \\
\hline Situação & & & & & & & \\
\hline A & & 7 & 3 & 1 & 1 & & 12 \\
\hline B & 2 & 6 & 1 & & 1 & 10 \\
\hline C & & 1 & & & & & 1 \\
\hline D & & 1 & & & & & 1 \\
\hline E & & 2 & & & & 2 \\
\hline F & 2 & 2 & & & & 5 \\
\hline G & & & & & & & 0 \\
\hline H & & & & & & & 0 \\
\hline I & & & & & & & 0 \\
\hline
\end{tabular}

\begin{tabular}{|l|l|l|l|l|l|l|l|}
\hline Praia & & & & & & \\
\hline Renda & A & B & C & D & E & & total \\
\hline Situação & & & & & & & \\
\hline A & & 4 & 1 & 2 & 2 & & 9 \\
\hline B & 1 & 2 & 1 & 4 & & & 8 \\
\hline C & & & & & & & 0 \\
\hline D & & & & & & & 0 \\
\hline E & & 2 & 2 & & & & 4 \\
\hline F & & 2 & 1 & 5 & 2 & & 10 \\
\hline G & & & 1 & & & & 1 \\
\hline H & & & & & & & 0 \\
\hline I & & & & & & & 0 \\
\hline & & & & & & & \\
\hline
\end{tabular}

\begin{tabular}{|l|l|l|l|l|l|l|l|}
\hline Centro & & & & & & & \\
\hline Renda & A & B & C & D & E & & Total \\
\hline Situação & & & & & & & \\
\hline A & & 1 & 2 & 1 & 1 & & 5 \\
\hline B & & 2 & & 2 & 3 & & 7 \\
\hline C & & & 1 & & 1 & & 2 \\
\hline D & & & & & & & 0 \\
\hline E & & & & 1 & 1 & & 2 \\
\hline F & & 1 & 1 & 1 & & & 3 \\
\hline G & & & & & & \\
\hline H & & & & & & & 0 \\
\hline I & & & & & & & 0 \\
\hline
\end{tabular}


Tabelas com local, renda, usos de conteúdo

\begin{tabular}{|l|l|l|l|l|l|l|l|}
\hline Morro & Renda & & & & & & \\
\hline Conteúdo & A & B & C & D & E & & Total \\
\hline a-no PC & 2 & 3 & & & 2 & & 7 \\
\hline b-no Cel & 1 & 1 & 1 & & & & 3 \\
\hline c-nada & 2 & 3 & & 1 & & & 6 \\
\hline $\begin{array}{l}\text { d- } \\
\text { descarta }\end{array}$ & 1 & 2 & & 1 & & & 4 \\
\hline e-DVD & 2 & & 1 & & & & 3 \\
\hline $\begin{array}{l}\text { f-n tem } \\
\text { nd }\end{array}$ & & 3 & 1 & & & & 4 \\
\hline
\end{tabular}

\begin{tabular}{|l|l|l|l|l|l|l|l|}
\hline Praia & Renda & & & & & & \\
\hline Conteúdo & A & B & C & D & E & & total \\
\hline A & & 4 & 2 & 3 & 2 & & 11 \\
\hline B & 1 & & 3 & 1 & 2 & & 7 \\
\hline C & & 2 & & 2 & & \\
\hline D & & 1 & & 2 & & & 3 \\
\hline E & & & & & & & 0 \\
\hline F & & & & & 1 & & 1 \\
\hline
\end{tabular}

\begin{tabular}{|l|l|l|l|l|l|l|l|}
\hline Centro & Renda & & & & & & \\
\hline conteúdo & A & B & C & D & E & & total \\
\hline A & & & & 2 & 1 & & 3 \\
\hline B & & & 2 & & 4 & & 6 \\
\hline C & & 1 & 2 & 1 & 1 & & 5 \\
\hline D & & & & & & & 0 \\
\hline E & & & & & & & 0 \\
\hline F & & 1 & & & & & 1 \\
\hline
\end{tabular}

